\title{
O PAPEL DA HEME OXIGENASE-1 NA MODULAÇÃO DE CÉLULAS DENDRÍTICAS LEVANDO À PROTEÇÃO DA LESÃO POR ISQUEMIA E REPERFUSÃO
}

Tese apresentada ao Programa de PósGraduação em Imunologia do Instituto de Ciências Biomédicas da Universidade de São Paulo, para obtenção do Título de Doutor em Ciências. 


\section{O PAPEL DA HEME OXIGENASE-1 NA MODULAÇÃO DE CÉLULAS DENDRÍTICAS LEVANDO À PROTEÇÃO DA LESÃO POR ISQUEMIA E REPERFUSÃO}

Tese apresentada ao Programa de PósGraduação em Imunologia do Instituto de Ciências Biomédicas da Universidade de São Paulo, para obtenção do Título de Doutor em Ciências.

Área de concentração: Imunologia

Orientador: Niels Olsen Saraiva Câmara

Versão original 
DADOS DE CATALOGAÇÃO NA PUBLICAÇÃO (CIP)

Serviço de Biblioteca e Informação Biomédica do

Instituto de Ciências Biomédicas da Universidade de São Paulo

(C) reprodução total

\section{Amano, Mariane Tami.}

O papel da heme oxigenase-1 na modulação de células dendríticas levando à proteção da lesão por isquemia e reperfusão / Mariane Tami Amano. -- São Paulo, 2011.

Orientador: Niels Olsen Saraiva Câmara.

Tese (Doutorado) - Universidade de São Paulo. Instituto de Ciências Biomédicas. Departamento de Imunologia. Área de concentração: Imunologia. Linha de pesquisa: Imunobiologia de Transporte.

Versão do título para o inglês: The role of heme oxygenase-1 in dendritic cell modulation leading to ischemia and reperfusion injury protection

Descritores: 1. Isquemia 2. Rim 3. Células dendríticas 4. Linfócitos T 5. Imunossupressão 6. Citocinas I. Câmara, Niels Olsen Saraiva II. Universidade de São Paulo. Instituto de Ciências Biomédicas. Programa de Pós-Graduação em Imunologia. III. Título. 
Candidato(a):

Título da Tese:

Orientador(a):
Mariane Tami Amano.

O papel da heme oxigenase-1 na modulação de células dendríticas levando à proteção da lesão por isquemia e reperfusão.

A Comissão Julgadora dos trabalhos de Defesa da Tese de Doutorado, em sessão pública realizada a I...... I... considerou

\section{( ) Aprovado(a) ( ) Reprovado(a)}

Examinador(a): Nome completo:

Instituição:

Examinador(a): Nome completo:

Instituição:

Examinador(a): Nome completo:

Instituição:

Examinador(a): Nome completo:

Instituição:

Presidente: Nome completo:

Instituição: 


\section{Certificado}

Certificamos que o protocolo registrado sob $n^{\circ} 054$ nas fls. 46 do livro 2 para uso de animais em experimentação, sob a responsabilidade de Niels Olsen Saraiva Camara Coordenador(a) da Linha de pesquisa "O papel da ativação especifica de linfócitos $T$ via TCR na lesão renal induzida pela isquemia e reperfusão" do qual participou(aram) o(s) alunos Mariane Tami Amano, está de acordo com os Princípios Éticos de Experimentação Animal adotado pelo Colégio Brasileiro de Experimentação Animal (COBEA) e foi aprovado pela COMISSÃO DE ÉTICA EM EXPERIMENTAÇÃO ANIMAL (CEEA) em 17.05.2007.

São Paulo, 18 de maio de 2007.

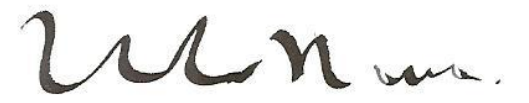

Prof. Dr. WOTHAN TAVARES DE LIMA

Coordenador CEEA - ICB/USP

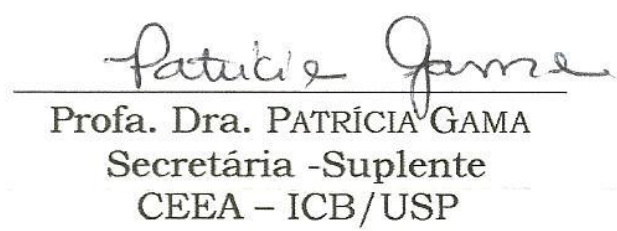


Aos meus pais, por nunca terem medido esforços em relação aos meus estudos, e por sempre terem estado ao meu lado. 


\section{AGRADECIMENTOS}

Agradeço ao meu caro orientador Niels, que tanto confiou em mim desde o início do doutorado, que lutou até o fim para que eu pudesse ter as melhores condições de trabalho, mesmo que pagando caro por burocracias de importações, que sempre se preocupou comigo dentro e fora do laboratório e que sem dúvida foi importante para o meu crescimento profissional e pessoal.

Aos colegas de laboratório $1^{\text {a }}$ geração: Rafinha, Vanessa, Rebecca, Mayra, Gian e especialmente a Gabi, que me ajudou muito com meus experimentos enquanto eu estava na França e pela amizade.

Aos colegas de laboratório $2^{-a}$ geração: Rosa, Giselle, Maristella+Richardt, Lê Minas, Jean, Andrea, Ênio, Pedro, Daniel, Reinaldo, Carla, Wesley, Carol, Felipe, Yuri, Bento, Marizinha e principalmente ao Matheus, Tárcio e Vinicius que além da amizade me ajudaram com experimentos que foram fundamentais para esta tese.

Às técnicas do lab: Claudinha e Meire, pelo suporte e principalmente pelo carinho.

Ao pessoal da UNIFESP: Marquinhos, Pati Semedo, Érica Naka, Angela, Candinho, Clarice,Marina, Cassiano e Vanessa, por sempre enviarem materiais para a USP.

Agradeço ao Prof. Yvon Lebranchu e à Profa. Florence Velge-Roussel pela orientação do projeto desenvolvido durante o doutorado sanduíche na Université François Rabelais em Tours, França, e pelo carinho que recebi de ambos e dos outros integrantes do laboratório: Christophe Baron, Cyrille Hoarau, Delphine, Audrey, Roxane, Romain Felix, Florence Uettwiller, Caroline, Romain Pinon e Carine. E agradeço in memoriam a Sylvie Vermersch.

Meus agradecimentos ao Prof. Ivan Moura e Prof. Renato Monteiro da Faculté de Médecine Xavier Bichat, Paris, França, que me acolheram durante 3 meses e muito me ensinaram durante este curto período. $\mathrm{E}$ aos colegas de laboratório da U699 que me ajudaram muito em meus experimentos e me apresentaram à cultura parisiense, especialmente: Pamella, Thiago, Céline, Houda, Christina, Émily, Damien e Stéphanie.

Ao Prof. Ésper Kallas, igualmente à Karina e à Bianca, que gentilmente nos permitiram utilizar o FACS enquanto o nosso passava por uma má fase.

À Profa. Lourdes Isaac que há 10 anos me adotou como aluna de iniciação científica no departamento de Imunologia do ICB-USP, me ensinou o bê-a-bá da pesquisa e sempre me incentivou na vida acadêmica. Aos amigos do 
laboratório de complemento que desde sempre me apoiaram: Marlene Florido, Lorena Bávia e Maria Isabel Delcolli.

Especial agradecimento à Edimara Reis pela grande amizade e por me ajudar em vários momentos de decisões e problemas, mas também por partilhar muitos momentos de alegria mesmo à distância.

Aos porteiros, pessoal da limpeza, secretarias da Imuno e do ICB e todos os funcionários que tornaram possível a realização do doutorado.

Às críticas e sugestões da banca de qualificação, que me auxiliaram nas alterações e enriquecimento do projeto para a tese.

À banca de defesa, que igualmente contribuirá para este trabalho e com certeza nos fornecerá novas visões sobre diversos pontos que levarão a novos projetos.

Aos professores Silvia Boscardin, Marcelo Bozza e Alexandre Basso por nos doar animais modificados que não possuímos no departamento de Imunologia.

Ao apoio financeiro da FAPESP que me concedeu a bolsa de doutorado, à CAPES pelo financiamento do doutorado sanduíche, à Pró-reitoria de pósgraduação e ao setor financeiro do ICB que providenciaram a passagem para 0 estágio em Paris e a Comissão de Pós-graduação da Imunologia que auxiliou diversos congressos durante meu doutorado.

Eterno agradecimento aos meus pais, que desde sempre me apoiaram, que comemoraram comigo cada bolsa e cada aceite de apresentação em congresso (mesmo de pôster), que sempre ouviram minhas histórias de camundongos e que sem dúvida foram essenciais para eu ter continuado nesta vida acadêmica.

Às minhas irmãs Luciane e Giovana pelo carinho e pelo apoio, principalmente para me ajudar com burocracias durante o meu sanduíche.

Aos amigos da biologia, todo o apoio e paciência, especialmente Luce, Vivi, May, Marcella, Kenji e Yoshi.

And last but not least, ao meu querido Welbert, por seu apoio, sua companhia, por ter feito parte de cada momento do meu doutorado, desde o dia em que eu ganhei a bolsa ao sanduíche congelante na Europa, por nossas eternas discussões científicas ou de qualquer coisa que acontece em nossas vidas e por me aguentar mesmo após um dia ruim de trabalho. 
"There are more things in heaven and earth... ...Than are dreamt of in your philosophy" William Shakespeare 


\section{RESUMO}

Amano MT. O papel da heme oxigenase-1 na modulação de células dendríticas levando à proteção da lesão por isquemia e reperfusão [Tese (Doutorado em Imunologia)]. São Paulo: Instituto de Ciências Biomédicas da Universidade de São Paulo; 2011.

A insuficiência renal aguda (IRA) atinge um grande número de pacientes hospitalizados e sua principal causa é a lesão de isquemia e reperfusão (IR). Algumas evidências recentes mostram a participação de linfócitos $T C D 4^{+}$e células dendríticas (DC) no desenvolvimento da lesão por IR. Entretanto, os mecanismos efetores envolvidos na participação destas células ainda não estão claros, o que dificulta o desenvolvimento de estratégias para diminuir a lesão tecidual. Estudos mostram que a enzima heme oxigenase-1, responsável pela quebra de heme em subprodutos, está relacionada à diminuição de respostas inflamatórias, como na IRA. No entanto, pouco se sabe sobre a participação de linfócitos T e DC neste modelo. Neste trabalho visamos investigar mais a fundo o papel do linfócito T CD4 ${ }^{+}$ e DC na lesão renal e a possível participação destas células na proteção da lesão por IR induzida pela HO-1. Para realizar este estudo, injetamos em camundongos a protoporfirina Hemin, um indutor de HO-1, e realizamos a IR. A lesão renal foi avaliada pelos níveis de uréia e creatinina no soro. Para ver a expressão gênica de citocinas utilizamos o RT-PCR quantitativo e a dosagem de proteínas foi feita por bioplex. A fenotipagem celular foi feitas por FACS. Observamos que a indução HO-1 levou à proteção da lesão por IR, acompanhada da diminuição das quimiocinas MCP-1 e RANTES. Confirmamos o envolvimento de linfócitos T CD4 ${ }^{+}$na lesão por IR utilizando animais deficientes deste tipo celular, e vimos in vitro a inibição de proliferação de linfócitos CD4+ na presença do Hemin. A diminuição de INF-g em animais tratados com Hemin sugeriu uma menor ativação de linfócitos T. Embora a transferência de esplenócitos tratados com Hemin tenha conferido proteção a animais CD4 deficientes, a transferência de células $\mathrm{CD} 4^{+}$purificadas tratadas com Hemin não apresentou diferença. Confirmamos então a participação de DC na IR com animais depletados das mesmas e a sua modulação por Hemin $n$ vitro. Observamos que o tratamento com Hemin in vivo alterou o fenótipo das DC após a reperfusão, apresentando mais CD86 e menos CD80. Por ser a principal célula produtora de TNF-a nesta lesão, verificamos os níveis de TNF-a e a expressão local da mesma e em ambos os casos o tratamento com Hemin suprimiu a produção de TNF-a. Em conjunto, concluímos que há proteção associada à $\mathrm{HO}-1$, que não envolve linfócitos $T$ diretamente, mas é capaz de modular a resposta inflamatória de DC, levando a uma menor produção de TNF-a.

Palavras-chave: Isquemia. Rim. Células dendríticas. Linfócitos T. Imunossupressão. Citocinas. 


\begin{abstract}
Amano MT. The role of heme oxygenase-1 in dendritic cells modulation leading to ischemia and reperfusion injury protection [Ph. D. thesis (Immunology)]. São Paulo: Instituto de Ciências Biomédicas da Universidade de São Paulo; 2011.

The acute kidney injury $(\mathrm{AKI})$ reaches a large number of patients in hospitals and it is mainly caused by ischemia and reperfusion (IR). Some recent evidences have shown the role of $C D 4^{+} \mathrm{T}$ cells and dendritic cells (DC) in the IR injury development. However, the effectors mechanisms involved in the participation of these cells are still not clear, which makes more difficult the development of strategies to diminish the tissue damage. Studies have shown that the heme oxygenase-1 enzyme, responsible for breaking heme in byproducts, is associated to a decrease in inflammatory responses, as in AKI. Besides, little is known about the involvement of $T$ cells and $D C$ in this model. In this work, we aim to further investigate the role of $\mathrm{CD}^{+} \mathrm{T}$ cells and $\mathrm{DC}$ in renal injury and the possible role of these cells in the IR injury protection induced by HO-1. To perform this study, we injected in mice the protoporphyrin Hemin, a HO-1 inducer, and we did the IR. The renal injury was evaluated by serum levels of urea and creatinine. To analyze cytokines gene expression we used quantitative RT-PCR and proteins dosage was done by bioplex. Cell phenotyping was performed by FACS. We observed that $\mathrm{HO}-1$ induction lead to IR injury protection combined with MCP-1 na RANTES chemokines decrease. We confirmed the $\mathrm{CD}^{+} \mathrm{T}$ cell involvement in IR injury using $\mathrm{T}$ cell deficient animals, and we saw in vitro, the proliferation inhibition of $\mathrm{CD}^{+} \mathrm{T}$ cells in Hemin presence. The IFN-g decrease in Hemin treated animals suggested less T cells activation. Although the transfer of hemin treated splenocytes had conferred protection to CD4 deficient mice, the transfer of hemin treated $\mathrm{CD} 4^{+}$purified cells did not differ from the other group. We confirmed the role of DC in IR with depleted mice and its modulation by Hemin in vitro. We observed that Hemin treatment in vivo altered the DC phenotype after reperfusion, presenting CD86 increase and CD80 decrease. Because DC is the main source of TNF-a in this lesion, we verified TNF-a levels and its local gene expression, and in both cases Hemin treatment suppressed TNF-a production. Taken together these results, we concluded that there is a protection associated to $\mathrm{HO}-1$, which do not involves $\mathrm{T}$ cells directly, but is able to modulate DC inflammatory response, leading to lower TNF-a production.
\end{abstract}

Keywords: Ischemia. Kidney. Dendritic cells. $\mathrm{T}$ cells. Immunosuppression. Cytokines. 


\section{LISTA DE ILUSTRAÇÕES}

Figura 1. Alterações da estrutura celular do túbulo proximal após IR.

Figura 2. Animais tratados com Hemin apresentam maior expressão de HO-1 e menor lesão renal induzida por IR. .34

Figura 3. Menor concentração de quimiocinas em animais tratados com Hemin. .......35

Figura 4. Animais nude são protegidos da lesão renal induzida por IR. 36

Figura 5. Animais MHC II KO e SCID são protegidos da lesão por IR. 37

Figura 6. Hemin inibiu a proliferação de linfócitos T CD4. 38

Figura 7. Tratamento com Hemin não altera a viabilidade celular. 39

Figura 8 Hemin não altera o fenótipo de ativação de linfócitos T CD4 do linfonodo renal. .40

Figura 9. Tratamento com Hemin não altera a presença de Tregs no linfonodo renal 41

Figura 10. Citocinas produzidas por linfócitos $T$ ativados são diminuídas com 0 tratamento de Hemin.

Figura 11. Transferência adotiva de esplenócitos tratados com Hemin protege animais da lesão pro IR.

Figura 12. Transferência adotiva de esplenócitos tratados com Hemin aumenta a freqüência de Tregs.

Figura 13. Transferência adotiva de esplenócitos tratados com Hemin não alterou os níveis séricos de citocinas.

Figura 14. Transferência adotiva de células CD4+ tratadas com Hemin não protege mais do que células não tratadas.....

Figura 15. Transferência adotiva de células $C D 4^{+}$tratadas com Hemin levou a uma menor proporção de Tregs no linfonodo renal.

Figura 16. Transferência de células $C D 4^{+}$tratadas com Hemin não alterou a expressão de TNFa e IL-10 após IR.

Figura 17. Depleção por clodronato diminui a frequência de $D C$ no baço e no rim. ...51

Figura 18. Depleção por clodronato não protege da lesão por IR. .52

Figura 19. Depleção por clodronato não altera o fenótipo de ativação das $D C$ restantes no rim.

Figura 20. Depleção de DC pela adição da toxina diftérica em animais CD11c-DTR. 54

Figura 21. Depleção de $D C$ em animais CD11c-DTR protegeu da lesão por IR com $48 \mathrm{~h}$ de reperfusão.

Figura 22. Depleção de $D C$ em animais $C D 11 c-D T R$ levou à maior ativação de $D C$ e linfócitos T CD4. 
Figura 23. $D C$ diferenciadas de medula óssea apresentam menor ativação na presença do Hemin.

Figura 24. Utilizando animais CD11c-YFP notamos uma maior ativação de DC na presença do Hemin.

Figura 25. DC do rim de animais C57BI6 apresentam mesma modulação de animais CD11C-YFP 61

Figura 26. Animais tratados com CORMs apresentam proteção e menos ativação de $D C$. 62

Figura 27. Tratamento com Hemin leva a menores concentrações de TNFa. 63

Figura 28. DC é a principal produtora de TNFa no rim. 64

Figura 29. O tratamento com Hemin leva a menor expressão gênica de TNFa no rim. 


\section{LISTA DE ABREVIATURAS E SIGLAS}

AMA - Actimicina A

APC- Antigen Presenting Cell - Célula Apresentadora de Antígeno

CFSE - Carboxyfluorescein Succinimidyl Ester - Carboxiflurosceína

CO - Carbon Monoxide - Monóxido de Carbono

CoPPIX - Cobalt Protoporphyrin IX - Cobalto de Protoporfirina IX

DC - Dendritic Cell - Célula Dendrítica

DT - Diphteria Toxin - Toxina Diftérica

ERO - Espécie Reativa de Oxigênio

FACS - Fluorescence-Activated Cell Sorting- Flow Cytometry - Citometria de Fluxo

HO-1 - Heme Oxygenase-1 - Heme Oxigenase-1

HSP - Heat Shock Protein

ICAM-1 - Inter-Cellular Adhesion Molecule-1 - Molécula de Adesão Intercelular

IFN-g - Interferon gama

IL - Interleucina

IR - Isquemia e Reperfusão

IRA - Injúria Renal Aguda

KO - Knockout - Deficiente

MCP-1 - Monocyte Chemotatic Protein-1 - Proteína Quimiotática de Monócitos - 1

MHC - Major Histocompatibility Complex - Complexo Principal de

Histocompatibilidade

NK - Natural Killer

PI - Propidium lodide - lodeto de Propídeo

RANTES - Regulated upon Activation, Normal T cell Expressed and Secreted -

Regulada sob Ativação, Expressa e Secretada por células T Normais.

Th - T helper - T auxiliadora

TLRs - Toll Like Receptors - Receptores do Tipo Toll

TNF-a - Tumor Necrosis Factor Alpha - Fator de Necrose Tumoral Alfa 


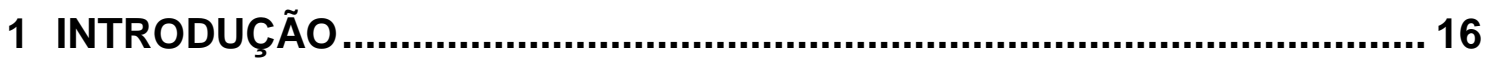

1.1 Lesão Renal Aguda Induzida por Isquemia e Reperfusão ..................... 16

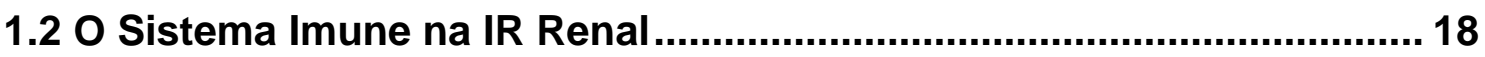

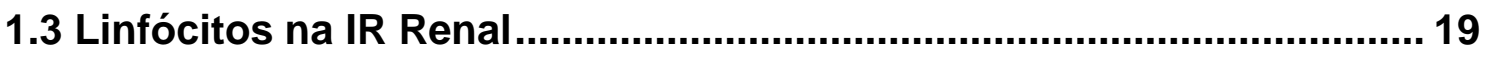

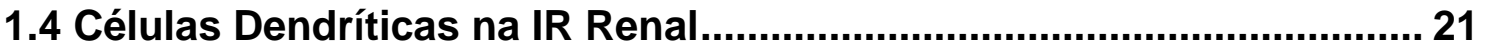

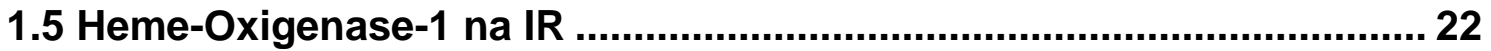

2 OBJETIVO

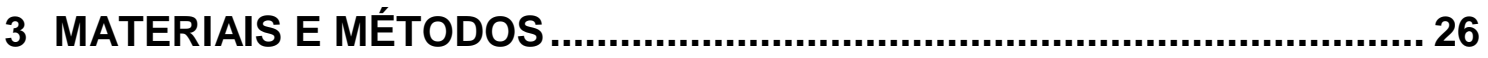

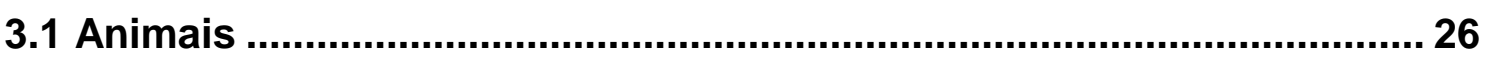

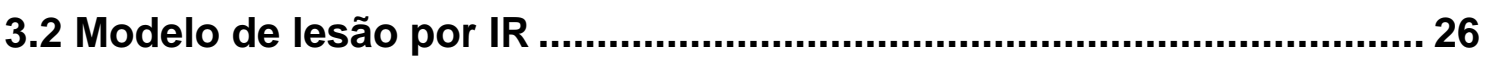

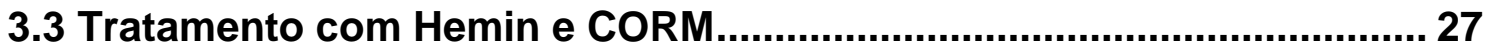

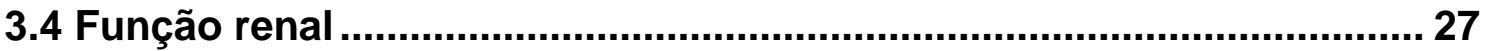

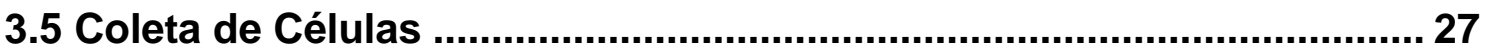

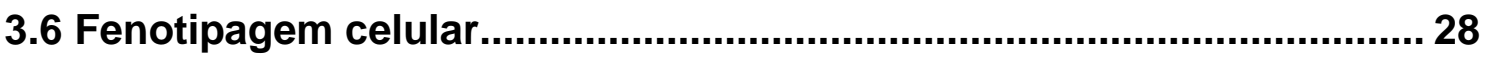

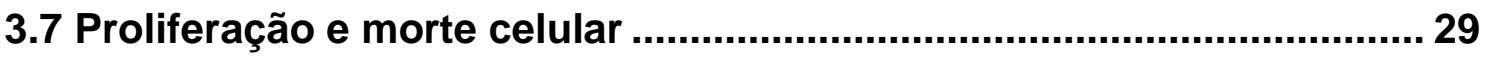

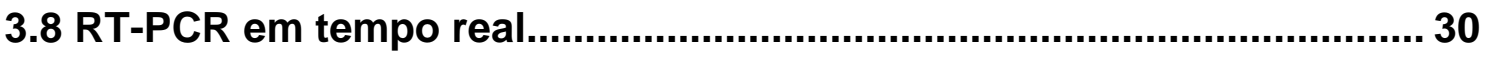

3.9 Bioplex

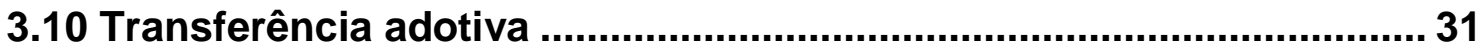

3.11 Depleção de Fagócitos por Clodronato................................................. 31

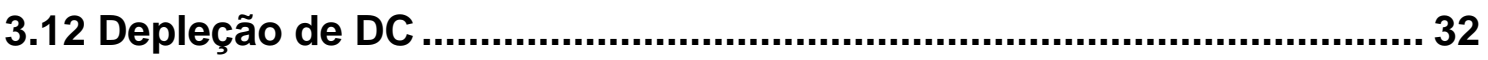

3.13 Diferenciação de DC a partir de células da medula óssea ................. 32

3.14 Análise estatística ........................................................................... 32

4 RESULTADOS

4.1 A HO-1 na proteção da lesão induzida por IR ........................................ 33

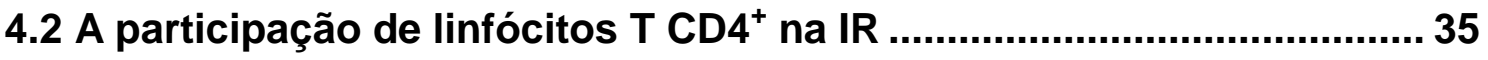

4.3 O efeito da HO-1 na ativação de linfócitos T CD4+ ............................... 37

4.4 A transferência de esplenócitos tratados com Hemin confere proteção 
4.5 A transferência de linfócitos T CD4 ${ }^{+}$tratados com Hemin não confere

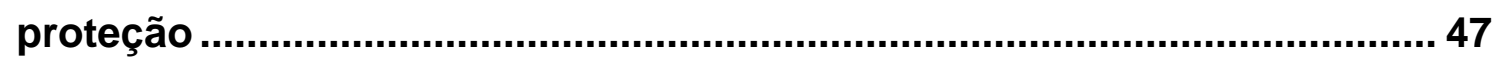

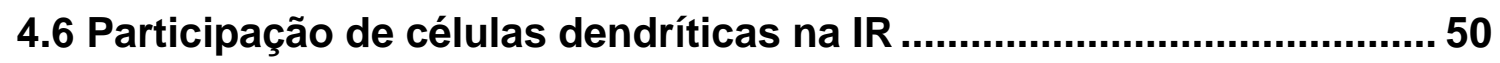

$4.7 \mathrm{O}$ efeito da HO-1 na ativação de DC......................................................57

4.8 O efeito do tratamento com CORM na ativação de DC .......................... 62

4.9 O Hemin diminui a produção de TNF-a de DC renais............................ 63

5 DISCUSSÃO

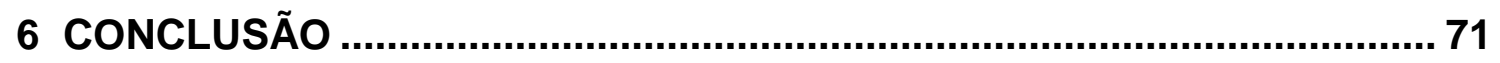

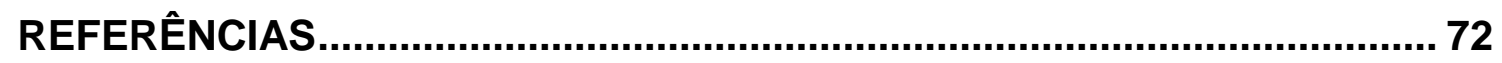




\section{INTRODUÇÃo}

\subsection{Lesão Renal Aguda Induzida por Isquemia e Reperfusão}

A lesão por isquemia e reperfusão (IR) se desenvolve a partir da interrupção do fluxo sangüíneo e conseqüente privação do suprimento de oxigênio para o rim [1]. É considerara a principal causa de insuficiência renal aguda (IRA). Embora os estudos sobre a IR tenha aumentado nas últimas décadas, pouco se mudou nos dados estatísticos dos hospitais com relação à IRA. Nos últimos 50 anos, as taxas de mortalidade de pacientes com IRA mantiveram-se semelhantes, em torno de $50 \%$ [2]. A IRA isquêmica está associada à falência de múltiplos órgãos e também à sepse [3], o que dificulta ainda mais o tratamento. A IRA pode prolongar a estadia de pacientes no hospital, o que consequentemente leva ao aumento de custos, mortalidade e morbidade [4].

No transplante renal (TxR), o órgão é inevitavelmente isquemiado e reperfundido. Na prática clínica, a forma mais comum de avaliar a extensão da lesão de IR é através da incidência de necrose tubular aguda pós TxR, que pode ser definida como a perda de função imediata do rim transplantado, levando à necessidade de diálise logo na primeira semana após a cirurgia, sendo também em alguns casos um importante fator da perda do enxerto a longo prazo $[5,6]$.

A patofisiologia da lesão renal aguda por IR pode ser explicada pelas seguintes etapas $[3,4]$ :

1- INÍCIO: Durante a isquemia, ocorre uma depleção de ATP que leva à quebra da homeostase de $\mathrm{Na}^{+}, \mathrm{K}^{+}$e $\mathrm{Ca}^{2+}$ nas células do túbulo proximal, afetando a reabsorção de nutrientes e levando ao acúmulo de metabólitos fosfolipídicos, desfosforilação, redistribuição e agregação generalizada de proteínas.

2- DURANTE: A queda de ATP também leva à perda da polaridade das células no epitélio do túbulo proximal, ocorrendo perda das microvilosidades da borda em escova, acompanhada de morte celular, por necrose e apoptose. Além disso, há uma maior geração de espécies reativas de oxigênio (ERO). Nesta fase inicial também ocorre uma intensa vasoconstriç̧ão, acompanhada da diminuição de vasodilatadores. Há aumento de moléculas de adesão como a 
intercelular-1 (ICAM-1), P-selectina e E-selectina no endotélio, acompanhado de uma infiltração de neutrófilos e monócitos. Citocinas pró-inflamatórias como IL-1 e TNF-a são expressas logo após a isquemia, bem como proteínas do sistema complemento como C5a, que age como fator quimiotático de neutrófilos e monócitos. Outras quimiocinas (MCP-1, IL-8, RANTES e CXCR3) também estão associadas ao complexo processo que decorre da isquemia, indicando uma resposta inflamatória.

3- REPARO: Em um momento mais tardio há a remoção de restos apoptóticos e ocorre a diferenciação de células viáveis, que neste caso não apresentam as microvilosidades, mas são capazes de proliferar para então sofrerem nova diferenciação e reconstituir o epitélio normal (Figura 1).

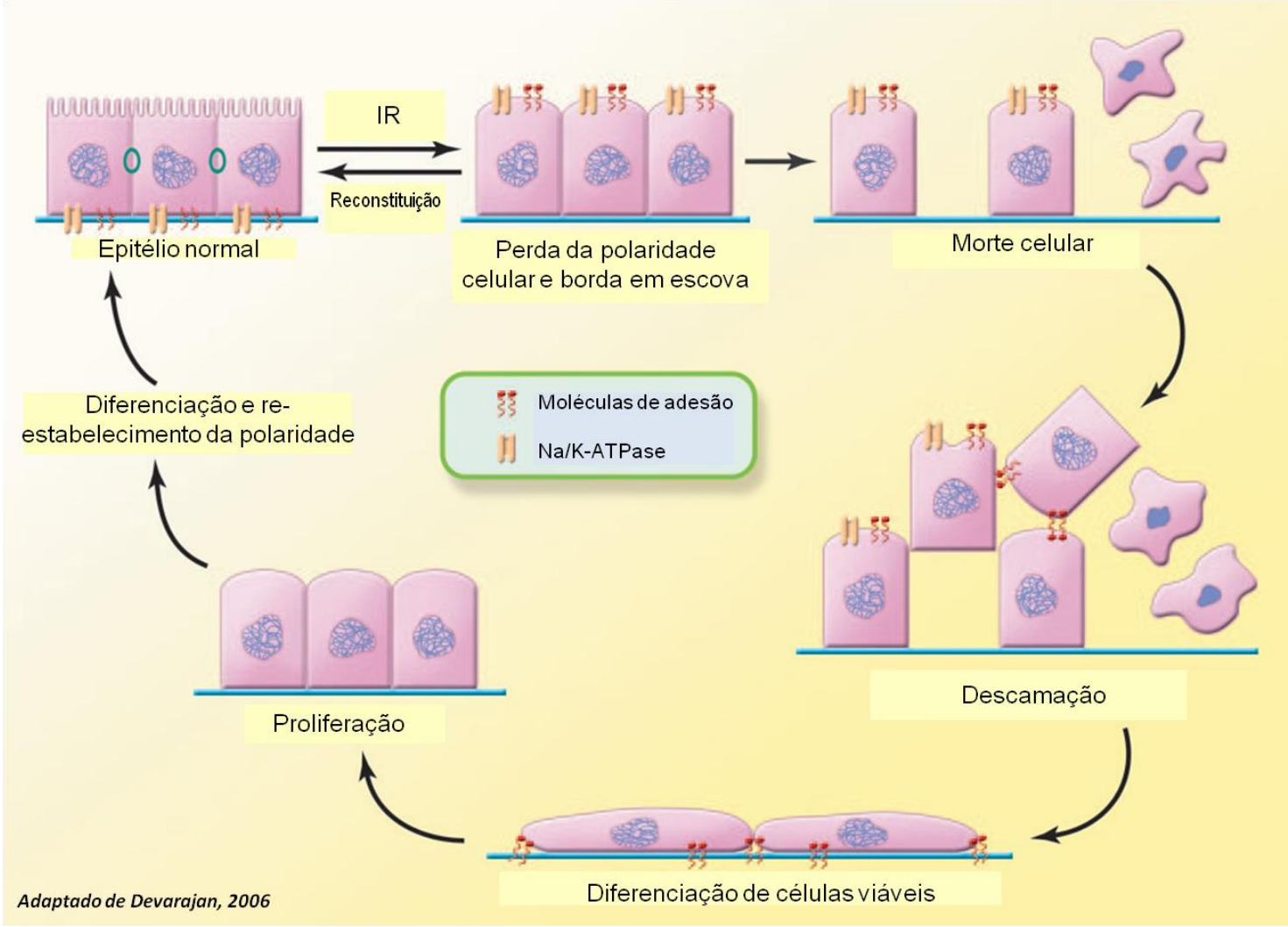

Figura 1. Alterações da estrutura celular do túbulo proximal após IR. O rim é submetido à isquemia $e$ as células do túbulo sofrem despolarização e perda das microvilosidades da borda em escova. Em casos de insulto leve, pode haver reconstituição imediata. Em insultos graves, há morte celular por apoptose ou necrose, descamação para retirada de restos celulares, diferenciação de células viáveis, proliferação celular e diferenciação para reconstituição do epitélio. 


\subsection{O Sistema Imune na IR Renal}

A hipóxia leva à inflamação rins isquemiados. A resposta inflamatória começa durante a isquemia e é acelerada durante a reperfusão com ativação endotelial, aumento da expressão de citocinas, quimiocinas, ativação de complemento e recrutamento de leucócitos [7]. Estes, ao se aderirem, liberam ERO, que por sua vez pode levar à indução de ligantes de Toll-like receptors (TLRs) endógenos como heat shock protein (HSP), ácido hialurônico e fibronectina [8]. A expressão de TLRs é aumentada após a IR, bem como a expressão da HSP 70 que é um ligante de TLR2 e TLR4 [9]. Além disso, animais deficientes de TLR2 e a inibição da síntese do mesmo levam à proteção da lesão por IR [10]. Animais TLR4 deficientes também apresentaram proteção na lesão por IR de forma MyD88 dependente e TRIF independente [11]. Na clínica, observou-se que TLR4 é constitutivamente expresso em todos os rins doados, mas esta expressão é aumentada em órgãos de doadores falecidos [12]. Uma vez que a ativação de TLRs induz a maturação de DC, estes trabalhos sugerem a participação da imunidade inata interligando a imunidade adaptativa neste modelo de lesão. Além de TLRs, o sistema complemento também faz parte da imunidade inata e parece contribuir fortemente no processo inflamatório que leva à injúria renal induzida pela isquemia. O fragmento C5a é um poderoso fator quimiotático de neutrófilos, monócitos e linfócitos $T$. No rim, ele é continuamente expresso por células tubulares renais e macrófagos [13] e tem sua expressão aumentada após a IR. Além disso, a inibição de C5a pelo uso de anticorpos monoclonais leva à proteção da lesão [14]. A via das lectinas também parece estar envolvida no processo de lesão por IR, pois a isquemia leva ao aumento de deposição de MBL no rim, seguida de deposição de C3, C6 e C9 [15]. Além da participação de proteínas do complemento, outros componentes solúveis estão envolvidos no processo de lesão por IR, como as citocinas e quimiocinas. Citocinas pró-inflamatórias como fator de necrose tumoral (TNF-a), interleucina (IL)-6 e IL-1 $\beta$, e quimiocinas como MCP-1, IL-8 e "regulated on activation normal $T$ cell expressed and secreted" (RANTES) são aumentadas após a IR [16].

As primeiras células a serem associadas à lesão por IR foram os neutrófilos. Por serem células de rápida migração ao tecido inflamado, era esperado encontrar um grande infiltrado deste tipo celular após a IR. No entanto, sua participação na 
lesão é controvérsia. Coelhos e ratos depletados de neutrófilos não apresentaram nenhuma proteção [17, 18]. Por outro lado, outros grupos observaram um papel fundamental dos neutrófilos após IR na produção de IFN-g, IL-17 e na regulação de NKT $[19,20]$. Já as células NK parecem participar principalmente da indução de apoptose neste modelo. Além do aumento deste tipo celular nos rins após IR, há também o aumento da expressão da molécula Rae-1 que interage com NKGD2 promovendo a citotoxicidade [21], além disso, animais depletados de NK foram protegidos da lesão por IR [22]. Linfócitos B também estão, de certa forma, envolvidos na injúria por $I R$, uma vez que animais deficientes de linfócitos $B$ são protegidos [23]. No entanto, a transferência adotiva de linfócitos $B$ para animais $B K O$ não restaura a lesão [23]. Sabe-se apenas que linfócitos $B$ limitam o reparo tecidual [24].

Monócitos e macrófagos estão presentes em rins pós-isquemia [25, 26]. A migração de monócitos neste modelo é dependente dos receptores de quimiocinas CCR2 e CX3CR1 [26]. A expressão das citocinas IL-6, TNF-a, IL-1b e TGF-b no rim são dependentes de macrófagos [27, 28], porém o aumento da expressão de IL-10 também, o que sugere que estas células tenham um papel na regeneração [29].

Assim, notamos que uma complexidade de eventos acontece durante a isquemia e a reperfusão que culminam na lesão renal aguda. A dependência de vários tipos celulares e moléculas solúveis, mostra que se trata de um sistema interligado e não de uma única via de ativação para a lesão.

\subsection{Linfócitos na IR Renal}

Inicialmente, a patogênese renal decorrente da lesão por IR tinha como foco principal a participação dos neutrófilos [30]. No entanto, há evidências de que o linfócito $T$ possui um papel nesse modelo, pois estudos 
mostram que essa célula participa do processo inflamatório da lesão por IR em outros órgãos como fígado [31], pulmão [32] e intestino [33]. Além disso, observou-se a presença de linfócitos em rins humanos pós IR [34] e que o bloqueio da via de co-estimulação CD28-B7 diminui a disfunção renal após IR em ratos [35, 36]. Também foi observado aumento de expressão de moléculas de adesão de leucócitos CD11/CD18 [18] e da ICAM-1 [37-39], e a produção de citocinas relacionadas a linfócitos na IRA [40-43] em camundongos.

Nosso grupo demonstrou que animais depletados de linfócitos T CD4 ${ }^{+}$, tanto animais $\mathrm{MHC}$ classe II KO, quanto camundongos tratados com anticorpos monoclonais anti-CD4 ${ }^{+}, \mathrm{GK} 1.5$, apresentaram melhor recuperação da função renal após a IR, comparados com animais C57BI/6 isquemiados [44]. De forma inversa, a transferência de linfócitos $\mathrm{T} \mathrm{CD}^{+}$em animais atímicos (nude), que são protegidos da lesão por IR, restaurou o fenótipo de lesão, evidenciando a participação destas células na IRA. No entanto, a transferência de linfócitos $T$ $\mathrm{CD}^{+}$, deficientes de CD28 ou incapazes de produzir a IFN-g, não foram capazes de restaurar tal fenótipo [45].

Embora alguns estudos [46, 47] indiquem uma associação entre a resposta Th1 e o desenvolvimento da lesão após IR, ainda não é está claro se o mecanismo envolvido depende da ação dos linfócitos ou das citocinas. Outro questionamento seria qual antígeno endógeno estaria primando estas células.

Schackleton já em 1998 mostrou que linfócitos T CD4 ${ }^{+}$eram autoreativos após a lesão de IR, ou seja, quando incubados com células tubulares pré-ativadas com IFN-g proliferavam [48].

Outro dado importante foi publicado por Savransky et al., onde animais deficientes para as cadeias $\alpha / \beta$ ou $\gamma / \delta$ do TCR eram parcialmente protegidos da lesão de IR, ainda que a produção de IFN-g não tenha sido diferente [49]. Além disso, a transferência de linfócitos TCR específico para OVA (DO11.10), para animais nude que normalmente são protegidos, levou ao aumento de lesão e células de animais OVA transgênicos com fundo genético RAG KO, levaram a uma pior lesão em comparação com as células dos animais apenas transgênicos para OVA, o que indica uma dependência de TCR, mas não uma especificidade [50]. 
Recentemente, foi relatada a participação de linfócitos $T \mathrm{CD}^{+}$no controle da lesão, pela atuação de Tregs [51-53]. A tranferência deste tipo celular em animais selvagens levou à melhora da lesão por IR [53], enquanto animais deficientes de Treg apresentaram piora na lesão [52].

O conjunto desses dados indica a contribuição de linfócitos $\mathrm{T} \mathrm{CD4}^{+}$no desenvolvimento e controle da lesão por IR, confirmando mais uma vez a complexidade da série de eventos envolvidos.

\subsection{Células Dendríticas na IR Renal}

Células dendríticas são células derivadas de monócitos, e consideradas células apresentadoras de antígeno (APC) sendo de grande importância para a ativação de lifócitos [54]. Na forma imatura, as DCs apresentam alta capacidade de fagocitose, baixa expressão de MHC de classe II e proteínas coestimulatórias e baixa capacidade de estimular proliferação de linfócitos $T$. Após a maturação, essas características tornam-se opostas [54]. Os sinais que levam a maturação das DCs e ativam a resposta de linfócitos $T$, derivam de produtos de lesão tecidual. $\mathrm{Na}$ ausência destes estímulos, as DCs atuam como controladoras da tolerância imune induzindo células reguladoras [55].

As DCs renais apresentam expressão de MHC classe II e proteínas coestimulatórias, e estão localizadas no interstício peritubular, onde ficam em contato com o epitélio e capilares peritubular [56]. Embora a especificidade de antígenos dos linfócitos $T$ ainda não tenha sido determinada, sabe-se que 0 bloqueio dos ligantes CD80/CD86 diminui a IRA [35]. Wu et al. [57] sugeriram que a indução da lesão por IR era capaz de aumentar o número de DC derivadas de células mononucleares de sangue periférico e a expressão de moléculas MHC de classe II no modelo de IR em ratos. Além disso, essas células seriam capazes de produzir mais IL-12 in vitro e de ativar melhor os linfócitos T levando à maior produção de IFN-g. O mesmo grupo [57] também mostrou que ratos submetidos à IR renal apresentavam menor diferenciação de DC derivadas de células da medula óssea, mas a capacidade de ativação destas DC não era alterada. Estes trabalhos mostram uma influência sistêmica 
da lesão por IR. Além de influenciar DC de maneira sistêmica, a lesão por IR também atua sobre células intra-renais. Dong et al. [58] mostraram que a IR unilateral era capaz de aumentar a ativação de linfócitos T mediada por DC nos linfonodos renais, tanto no linfonodo do lado isquemiado, quanto no lado não isquemiado, mais uma vez mostrando a influência sistêmica e o envolvimento de $\mathrm{DC}$ renais na ativação de linfócitos $\mathrm{T} C D 4^{+}$. Também demonstraram que as DCs renais fagocitam partículas filtradas e não filtradas da circulação e migram do rim para o linfonodo [58]. Este mesmo grupo, caracterizou as DC renais em $\mathrm{CD} 11 \mathrm{C}^{+} \mathrm{F} 4 / 80^{+}$e $\mathrm{CD} 11 \mathrm{C}^{+} \mathrm{F} 4 / 80^{-}$, dentre elas, o primeiro grupo apresenta expressão elevada de moléculas de ativação (MHC II, CD80, CD86 e CD40) e das proteínas IL-6, MCP-1 e RANTES após IR e são as principais células produtoras de TNF-a no rim nesta lesão [59].

Desta forma, a IR parece levar as DC a um perfil ativado próinflamatório, possivelmente, orquestrando a ativação de outras células.

\subsection{Heme-Oxigenase-1 na IR}

A HO-1 é uma enzima cliva pontes de carbono da molécula heme na dependência de oxigênio e nicotinamida adenina dinucleótido fosfato (NADPH), levando à produção de biliverdina, monóxido de carbono (CO) e ferro [60]. Existem 3 isoformas de heme oxigenase: HO-1, HO-2 e HO-3, no entanto, só a primeira é induzível [61]. Os estímulos capazes de induzir a HO1, que é uma HSP32, são diversos estímulos, dentre eles a hipóxia, endotoxinas e ERO. O papel protetor da HO-1 pode ser uma combinação de ações que envolvem a redução de heme livre, considerado tóxico, e a produção de moléculas protetoras (biliverdina, $\mathrm{CO}$ e ferro) [62]. Acredita-se que a molécula Heme livre possa gerar uma resposta inflamatória moderada seguida de uma reposta regulatória atribuída à ação de HO-1 [63].

Biliverdina é convertida pela biliverdina redutase à bilirrubina. Esta age como potente antioxidante sendo um dos principais no soro [64]. Bilirrubina também está associada ao aumento de Treg e promove maior aceite em 
modelo alogênico [65]. Na IR renal, a injeção de bilirrubina leva à proteção da lesão renal [66].

Embora o CO seja conhecido por ser um gás tóxico a certas concentrações na atmosfera, também tem um papel anti-oxidante, capaz de estimular genes anti-oxidantes e apresentar efeitos anti-apoptóticos [67]. Exatamente por ser tóxico em altas quantidades, o uso terapêutico deste produto torna-se limitado. Para tanto, Motterlini desenvolveu componentes que liberam CO (CORMs). Um dos tipos de CORM (CORM-2) levou à proteção da lesão da IR hepática, acompanhada da diminuição de TNF-a e IL-6 [68]. A inibição de HO-1 com a posterior adição de CORM foi capaz de levar à proteção da lesão por IR renal, indicando um papel de proteção de CO independente da ação da HO-1 [69].

O ferro também é um potente antioxidante, mas esta ação é mais eficaz se o mesmo se encontra desligado do anel de heme. A ferritina é uma proteína capaz de sequestrar ferro, retirando-o da molécula heme. Viu-se que a adição de ferritina levou à proteção da lesão por IR renal [70], corroborando mais uma vez os dados de proteção pela HO-1.

Tullius et al.,[71] mostraram que com uma única dose $(5 \mathrm{mg} / \mathrm{mL})$ intraperitoneal de outra porfirina indutora de HO-1: cobalto de protoporfirina IX (CoPPIX), ratos eram protegidos da lesão pós IR com menor expressão de TNF-a, IFN-g e bcl-x e maior infiltração de monócitos/macrófagos e linfócitos T CD8+. Nosso grupo demonstrou a proteção por CoPPIX no modelo de lesão por IR e pela toxicidade da droga ciclosporina em camundongos [72]. A metaloporfirina sintética Hemin é capaz de aumentar a expressão de HO-1 e consequentemente apresentar uma ação citoprotetora, anti-inflamatória e antiapoptótica em diversos modelos. Na lesão renal aguda induzida por IR, o Hemin teve um papel protetor, apresentando níveis de creatinina, uréia e malonaldeído similares ao controle [73]. No modelo de lesão renal crônica induzida por IR também foi amenizada, apresentando menor proteinúria, albuminúria, inflamação e proteínas pró-fibróticas [74]. Estes estudos sugerem a aplicação do hemin como um bom indutor de HO-1 para possível uso terapêutico. 
A lesão de IR é o principal fator etiológico da necrose tubular aguda pós-transplante, e leva a menor sobrevida do enxerto, a curto e longo-prazo, além de ser a principal causa da IRA. Portanto, o entendimento dos mecanismos da lesão por IR é crucial para o desenvolvimento de terapias. Os linfócitos $\mathrm{T} \mathrm{CD4}^{+}$e as células dendríticas desempenham um papel importante nesta fisiopatogenia e são moduláveis em diversos modelos de lesão. Nossa hipótese é de que o aumento da HO-1 seja capaz de inibir a ativação de linfócitos $\mathrm{T} \mathrm{CD4}{ }^{+}$ou das $\mathrm{DC}$, levando à menor lesão induzida por IR. 


\section{OBJETIVO}

Verificar o papel da heme oxigenase-1 na proteção da lesão renal induzida por IR e investigar o possível envolvimento de linfócitos $\mathrm{TCD}^{+} \mathrm{e}$ células dendríticas como responsáveis pela proteção. 


\section{MATERIAIS E MÉTODOS}

\subsection{Animais}

Utilizamos camundongos com o background C57BI/6 $\left(\mathrm{H} 2^{\mathrm{b}}\right)$, isogênicos, machos, com idade entre 8 e 12 semanas, pesando de 20 a 28 g. As linhagens utilizadas foram: nude, MHC de classe II knockout (KO), SCID, CD11c-DTR, CD11c-YFP, OTII e C57BI/6 como controle. Os animais foram fornecidos pelo Biotério de Camundongos Isogênicos da Universidade de São Paulo (USP), da Universidade Federal de São Paulo e pela professora Silvia Boscardin do departamento de Parasitologia do Instituto de Ciências Biomédicas (ICB) da USP. Antes e após os procedimentos cirúrgicos, os animais foram acondicionados em microisoladores coletivos, contendo no máximo cinco animais por microisolador, com ciclo artificial claro/escuro de 12 horas, à temperatura ambiente constante de $22{ }^{\circ} \mathrm{C}$ e com suprimentos de água e alimento autoclavados disponíveis todo o tempo. Todas as práticas utilizadas com animais foram aprovadas pela Comissão de Ética em Experimentação Animal do ICB da USP e registradas sob $n^{\circ} 054$ nas folhas 46 do livro 2.

\subsection{Modelo de lesão por IR}

O modelo de indução de IRA por isquemia experimental foi adaptado de Kelly et al.[38, 48]: os animais foram submetidos à anestesia composta por $100 \mu \mathrm{l}$ de xilazina $(10 \mathrm{mg} / \mathrm{ml})$ e $200 \mu \mathrm{l}$ de cetamina $(50 \mathrm{mg} / \mathrm{ml})$ ambos da Agribands do Brasil Ltda, São Paulo, no volume final de $2 \mathrm{ml}$ em salina $(\mathrm{NaCl}$ $0,1 \%$ ), utilizando-se a dose de $200 \mu \mathrm{l}$ por animal via intraperitoneal (IP). Os pedículos renais foram dissecados e ocluídos com clamps microvasculares (Rocca, São Paulo, Brasil e Roboz Surgical Instrument Company, EUA) por 45 minutos. Durante o procedimento cirúrgico, os animais foram mantidos hidratados com soro fisiológico e a temperatura constante $\left(\sim 37^{\circ} \mathrm{C}\right) \mathrm{com}$ a utilização de um equipamento de aquecimento. Os clamps foram removidos após o período mencionado e o abdômen do animal suturado com agulha/linha $45 \mathrm{~cm} \times 17 \mathrm{~mm}$ (Technofio, Goiás, Brasil). Os animais foram 
aquecidos por iluminação indireta infravermelha até completa recuperação da anestesia e então, mantidos em condições controladas até o momento do sacrifício. Como controle, os animais sham foram apenas dissecados, mas não ocluídos e após 45 min foram suturados.

\subsection{Tratamento com Hemin e CORM}

Para utilizar um modelo conhecido de proteção contra a lesão por IR, foram injetados $25 \mathrm{mg} / \mathrm{kg}$ de animal de Hemin i.p. $24 \mathrm{~h}$ antes da cirurgia de IR. Os animais foram sacrificados e tiveram seus órgãos coletados 0,5; 6 ou $24 \mathrm{~h}$ após a cirurgia. No tratamento de CORM, utilizamos $10 \mathrm{mg} / \mathrm{kg}$ de animal, também injetatos i.p. $1 \mathrm{~h}$ antes da cirurgia de IR e coletados com $24 \mathrm{~h}$ de reperfusão.

\subsection{Função renal}

Avaliamos os níveis de creatinina e uréia no soro. Para tanto, coletamos amostras de sangue pelo plexo ocular, imediatamente antes do sacrifício do animal. Os níveis de creatinina plasmática foram dosados pelo teste de Jaffé: adicionamos $100 \mu \mathrm{l}$ de ácido sulfúrico 1,84\%, $100 \mu \mathrm{l}$ de tungstato de sódio 10\% e $200 \mu \mathrm{l}$ de água a $100 \mu \mathrm{l}$ de soro para a desproteinização. Centrifugamos a $4000 \mathrm{~g}$ por $10 \mathrm{~min}$, coletamos $200 \mu \mathrm{l}$ do sobrenadante e acrescentamos $80 \mu \mathrm{l}$ de ácido pícrico $2 \%$ e $20 \mu$ de hidróxido de sódio a 10\%. A análise da concentração das amostras foi feita pela leitura da absorbância a $520 \mathrm{~nm}$ juntamente com a leitura de uma curva padrão. A dosagem de uréia sérica foi feita com um kit colorimétrico (Urease da Labtest) de acordo com as instruções do fabricante. O espectrofotômetro utilizado em ambos os casos foi o Synergy HT (Biotek).

\subsection{Coleta de Células}

Para coleta e manutenção de células foi utilizado o meio de cultura RPMI 16 (Life technologies) previamente preparado com $2 \mathrm{~g} / \mathrm{L} \mathrm{NaHCO}_{3}, 4,8$ g/L Hepes: pH 7,0 e filtrado em 0,22 $\mu \mathrm{m}$. Para uso em cultura, foram 
adicionados $1 \%$ de antibióticos (penicilina e estreptomicina) e 10\% de soro bovino fetal inativado (SBF). Para coleta de material, o mesmo meio de cultura foi utilizado, com apenas $2 \%$ de SBF.

\section{- Baço}

O baço dos animais foi coletado em meio RPMI-SBF 2\% logo após a coleta de sangue. Os baços foram levados para um ambiente estéril (fluxo laminar), onde foram macerados em filtro $70 \mu \mathrm{m}$. As células foram então centrifugadas a $700 \mathrm{~g}$ por $10 \mathrm{~min}$ a $20{ }^{\circ} \mathrm{C}$. Para retirada das hemácias, adicionamos $2 \mathrm{~mL}$ de tampão de lise $\left(155 \mathrm{mM}\right.$ de $\mathrm{NH}_{4} \mathrm{Cl}, 10 \mathrm{mM}$ de $\mathrm{NaHCO}_{3} \mathrm{e}$ $0,1 \mathrm{mM}$ de EDTA) e incubamos por 5 minutos à temperatura ambiente. As células foram então lavadas 2 vezes em RPMI-SBF $2 \%$ e utilizadas para transferência adotiva ou marcadas para análise.

- Linfonodos

Para fenotipagem de linfócitos após a IR foram coletados linfonodos peri-renais. Estas coletas também foram feitas em RPMI-SBF 2\%. Os linfonodos foram macerados em filtro $70 \mu \mathrm{m}$, centrifugados a $700 \mathrm{~g}$ por $10 \mathrm{~min}$ a $4 \stackrel{\circ}{\circ} \mathrm{C} \mathrm{e}$ posteriormente marcados com anticorpos de superfície descritos a seguir.

\section{- $\operatorname{Rim}$}

Um rim de cada animal foi coletado em $4 \mathrm{~mL}$ de colagenase IV (2 $\mathrm{mg} / \mathrm{mL}$ ) cortado em pedaços para facilitar a digestão do mesmo durante a incubação de 40 min a $37^{\circ} \mathrm{C}$. Para parar a reação adicionamos $1 \mathrm{~mL}$ de RPMISBF $10 \%$. Maceramos em filtros os restos não digeridos e centrifugamos a 700 $g$ por 10 min a $4 \stackrel{\circ}{\circ}$. O sobrenadante foi retirado e $\circ$ pellet de células ressuspendido em 2,5 mL de Percoll (GE Healthcare) 35\%. Esta nova suspensão foi lentamente colocada sobre outra fase de $2,5 \mathrm{ml}$ de Percoll $70 \%$ e centrifugadas a $1000 \mathrm{~g}$ sem "break" por $30 \mathrm{~min}$ a $20^{\circ} \mathrm{C}$. A fase utilizada para análise das células foi a intermediária [59, 75].

\subsection{Fenotipagem celular}

Para fenotipagem celular, utilizamos $2-10 \times 10^{5}$ células marcadas com anticorpos (BD biosciences e Biolegend) para moléculas presentes em linfócitos $T$ (anti- CD4-Pacific Blue, anti-CD69-FITC e anti-CD25-PE) e em 
células dendríticas (anti-CD11c-Pacific Blue, anti-CD80-PercP, anti-CD86APC, anti-CD40-PE, anti-IAb-FITC) diluídos 1:200 ressuspendidos em $10 \mu \mathrm{L}$ de tampão fosfato tampão fosfato (PBS - $\mathrm{KH}_{2} \mathrm{PO}_{4} 5 \mathrm{mM}, \mathrm{K}_{2} \mathrm{HPO}_{4} 1,2 \mathrm{mM} \mathrm{e}$ $\mathrm{NaCl} 150 \mathrm{mM}$ : pH 7,0) com SBF 2\% incubados a $4 \stackrel{\circ}{\mathrm{C}}$ por $30 \mathrm{~min}$. Após a incubação, foram feitas 2 lavagens com PBS-SBF $\%$ e foi feita a fixação celular utilizando-se paraformaldeído $0,1 \%$ e incubação a $4{ }^{\circ} \mathrm{C}$ por $20 \mathrm{~min}$. Uma nova lavagem foi feita e as células foram ressuspendidas em PBS-SBF $2 \%$ até a análise por citometria de fluxo (FACS) no leitor FACSCanto (BD biosciences) do departamento de Imunologia ICB/USP. Para marcação de Tregs, iniciamos a marcação extracelular e depois fizemos a intra-celular com o anti-FOXP3-APC, (kit da eBiosciences) conforme as instruções do fabricante, que consistia em fixar as células em um fixador e permeabilizador durante 30 min e lavar 2 vezes com um permeabilizador antes da marcação. Utilizamos a diluição de 1:100 do anticorpo e seguimos como o protocolo anterior. A análise dos resultados foi feita pelo software FlowJo. Para análise de citocina, coletamos as células como descrito e incubamos por $4 \mathrm{~h}$ com 50 $\mathrm{ng} / \mathrm{ml}$ de phorbol 12-myristate 13-acetate (PMA), $1 \mu \mathrm{g} / \mathrm{ml}$ ionomicina e $1 \mu \mathrm{g} / \mathrm{ml}$ de brefeldina (SIGMA), e procedemos como na marcação intra-celular, utilizando o anticorpo anti-TNFa-APC (BD biosciences).

\subsection{Proliferação e morte celular}

Utilizamos $5 \times 10^{5}$ de esplenócitos de animais OTII por poço de placa de 96-poços, marcados com $5 \mu \mathrm{M}$ carboxiflurosceína (CFSE - Life technologies) na presença de $2 \mu \mathrm{g} / \mathrm{ml}$ de peptídeo OVA (Proteimax) em meio de cultura RPMI-SBF 10\%. Para ver a ação do Hemin nestas células, adicionamos $15 \mu \mathrm{M}$ por poço. A análise de proliferação foi feita no $4^{\circ}$. dia de cultura por FACS com marcação da molécula CD4. Para análise de morte celular, utilizamos o mesmo protocolo, porém não marcamos as células com CFSE, e fizemos a marcação com anexina $\mathrm{V}$, na presença de $\mathrm{Ca}^{2+}$ e iodeto de propídeo (PI - SIGMA) no dia 5 de cultura, a análise também foi feita por FACS. 


\subsection{RT-PCR em tempo real}

Para análise de expressão de citocinas (HO-1, IFNg, IL-2, FOXP3 e TNFa) utilizamos o método de PCR em tempo real que depende de 3 etapas:

- Extração de RNA

Para extração de RNA de rins utilizamos o Trizol (Life technologies) e seguimos as instruções do fabricante. Após precipitação e lavagem do RNA total, foram feitas leituras da concentração de RNA obtida, usando o aparelho NanoDrop (Thermo Scientifc NanoDrop).

\section{- Síntese de cDNA}

Para síntese do cDNA incubamos $2 \mu \mathrm{g}$ deste RNA total no tampão DNase I Reaction Buffer (Promega) e tratamos com $1 \mu \mathrm{L}$ de RNase-Free DNAse (Promega) por $15 \mathrm{~min}$ a $25^{\circ} \mathrm{C}$. Em seguida adicionamos $0,5 \mu \mathrm{M}$ de OligodT (GE Healthcare) e $1 \mu \mathrm{L}$ EGTA $20 \mathrm{mM}$ (Promega) e incubamos a $65 \stackrel{\circ}{\mathrm{C}}$ por 10 min deixando no gelo por mais $5 \mathrm{~min}$. Acrescentamos então $1 \mu \mathrm{L}$ BSA (Bovine Serum Albumin), o tampão M-MLV $1 \mathrm{x}, 10 \mu \mathrm{L}$ de deoxynucleotídeo trifosfato (dNTP e) $10 \mathrm{mM}$ e $2 \mu \mathrm{L}$ enzima M-MLV Reverse Transcriptase (Promega), e novamente aquecemos por $37 \stackrel{\circ}{\circ} \mathrm{C}$ por 60 min e $65 \stackrel{\circ}{\circ} \mathrm{C}$ por 10 $\min$.

\section{- PCR em tempo real}

Utilizamos sondas com primers Taqman (LifeTechnologies) para análise da expressão dos genes mencionado e HPRT como controle. Para a reação, utilizamos $4 \mu \mathrm{L}$ de cDNA diluído 1:10, 0,5 $\mu \mathrm{L}$ de sonda, $5 \mu \mathrm{L}$ de mastermix Taqman e completamos o volume de $10 \mu \mathrm{L}$ com água DEPC. A amplificação foi realizada em aparelho ABI Prism 7300 sequence detection system (Applied Biosystem). As condições de amplificação foram as seguintes: $50 \stackrel{\circ}{\circ}$ por 2 min e $95{ }^{\circ} \mathrm{C}$ por 10 min e 45 ciclos de $95 \stackrel{\circ}{\circ} 15 \mathrm{~s}, 60 \stackrel{\circ}{\circ} 1 \mathrm{~min}$. Para análise, uma relação comparativa entre os ciclos da reação (CT) foi usada para determinar a expressão gênica, em relação ao controle HPRT (gene constitutivo). Dessa maneira, níveis arbitrários de mRNA foram expressos como uma diferença de "n" vezes em relação ao calibrador. Para cada amostra, os valores $\left(C_{T}\right)$ dos genes alvo foram normalizados e o valor usado para demonstrar a expressão relativa dos genes alvo foi calculado utilizando-se a expressão $2^{-\Delta \Lambda C T}$ 
(Previamente descrita por K. Livak - PE - Applied Biosystems; Sequence Detector User Bulletin 2).

\subsection{Bioplex}

Para análise do bioplex, foram utilizados kits da Millipore e BioRad. O filtro da placa foi pré-umedecido com $100 \mu \mathrm{l}$ do Tampão do Ensaio Bio-Plex. $50 \mu \mathrm{l}$ das beads foram adicionados e submetidos ao vácuo. Em seguida, foram feitas duas lavagens de $100 \mu \mathrm{l}$ cada com o Tampão de Lavagem BioPlex. $50 \mu \mathrm{l}$ dos padrões foram adicionados e incubados por $30 \mathrm{~min}$ à temperatura ambiente (T/A) em agitação. As placas foram então lavadas 3 vezes e foram adicionados os anticorpos de detecção $(25 \mu \mathrm{l} /$ poço). A placa foi então coberta e foi feita a incubação de $30 \mathrm{~min}$ T/A em agitação. Novamente foram feitas 3 lavagens e adicionada a estreptavidina e mais uma incubação de $10 \mathrm{~min}$ T/A em agitação. Mais 3 lavagens foram realizadas e as beads foram ressuspendidas em $125 \mu \mathrm{l}$ do Tampão do Ensaio Bio-Plex. Por fim as placas foram lidas no aparelho de Bioplex.

\subsection{Transferência adotiva}

Separamos esplenócitos como descrito acima e ressuspendemos em PBS. Injetamos $1 \times 10^{7}$ de células i.v. pelo plexo ocular em animais MHC ॥ KO. Após $24 \mathrm{~h}$ realizamos a cirurgia de IR e em $24 \mathrm{~h}$ coletamos os rins e linfonodos.

\subsection{Depleção de Fagócitos por Clodronato}

Para o preparo do lipossomo, foram adicionados $50 \mathrm{mg}$ de Filme de eggPC em $500 \mu$ de éter etílico contendo 8mg de colesterol. Em seguida, esta solução foi injetada em $5 \mu \mathrm{l}$ de uma solução de clodronato $50 \mathrm{mM}$. Esta injeção ocorreu a uma velocidade de $10 \mathrm{ml} /$ hora sob fluxo de $\mathrm{N}_{2}$. Após completa evaporação do éter, a suspensão resultante foi transferida para um tubo que foi centrifugado a $15000 \mathrm{rpm}$ a $25{ }^{\circ} \mathrm{C}$ por $30 \mathrm{~min}$. O sobrenadante foi 
descartado e a amostra foi ressuspendida em salina ( $\mathrm{NaCl}$ 0,9\%). Este procedimento foi realizado pelo laboratório da Profa. Iolanda Cuccovia do Instituto de Química da USP.

Para a depleção, nós injetamos $200 \mu \mathrm{l}$ da solução de lipossomos contendo clodronato i.p. $24 \mathrm{~h}$ antes da cirurgia e uma segunda dose de $100 \mu \mathrm{l}$ da mesma solução logo após a cirurgia.

\subsection{Depleção de DC}

Para depletar as DC, utilizamos animais CD11c-DTR, que expressam o receptor para a toxina diftérica (DT) na região promotora do CD11c, molécula específica de DC. Neste modelo injetamos $4 \mu \mathrm{g} / \mathrm{kg}$ de animal da DT (SIGMA) via i.p $24 \mathrm{~h}$ antes da cirurgia.

\subsection{Diferenciação de DC a partir de células da medula óssea}

Coletamos o fêmur de camundongos C57Bl6 em PBS e retiramos as células da medula óssea com uma seringa. Foi feita a lise de hemácias com tampão de lise, descrito acima, e as células foram incubadas por sete dias na presença de fator estimulador de colônia de macrófago e granulócitos (GMCSF - SIGMA) $20 \mathrm{ng} / \mathrm{ml}$. Após 4 dias de cultura foi feita a troca de meio com nova adição de GM-CSF e no sexto dia foi feito o estímulo com Hemin 2 horas antes do LPS (SIGMA) $20 \mathrm{ng} / \mathrm{ml}$. A análise de moléculas de ativação de DC foram feitas por FACS.

\subsection{Análise estatística}

Para análise estatística comparativa de dois grupos foi utilizado o teste Student-t. E para análise de mais de dois grupos amostrais foi utilizado o ONE-way ANOVA teste Tukey. 


\section{RESULTADOS}

\subsection{A HO-1 na proteção da lesão induzida por IR}

A HO-1 é uma enzima responsável por clivar a molécula heme em biliverdina, íons de ferro e monóxido de carbono. $\mathrm{O}$ aumento de expressão da mesma está associado a várias respostas anti-inflamatórias. Como nosso grupo já mostrou que o aumento de HO-1 está associado à proteção da lesão induzida por IR, decidimos investigar a influência desta molécula na modulação de $\mathrm{DC}$ e linfócitos $\mathrm{T}^{\mathrm{C}} \mathrm{CD}^{+}$no modelo de IR renal. Para tanto, injetamos 25 $\mathrm{mg} / \mathrm{kg}$ de Hemin, um indutor de HO-1, via i.p. em camundongos C57BI6 $24 \mathrm{~h}$ antes da cirurgia. Analisamos a expressão da HO-1 no rim destes animais e observamos que animais tratados com Hemin apresentaram maior expressão de HO-1 após a IR quando comparados com animais não tratados (Figura 2 A). Analisamos então a lesão renal através da concentração sérica de uréia e creatinina e observamos que animais tratados com Hemin apresentavam menor lesão (Figura 2 B e C). 


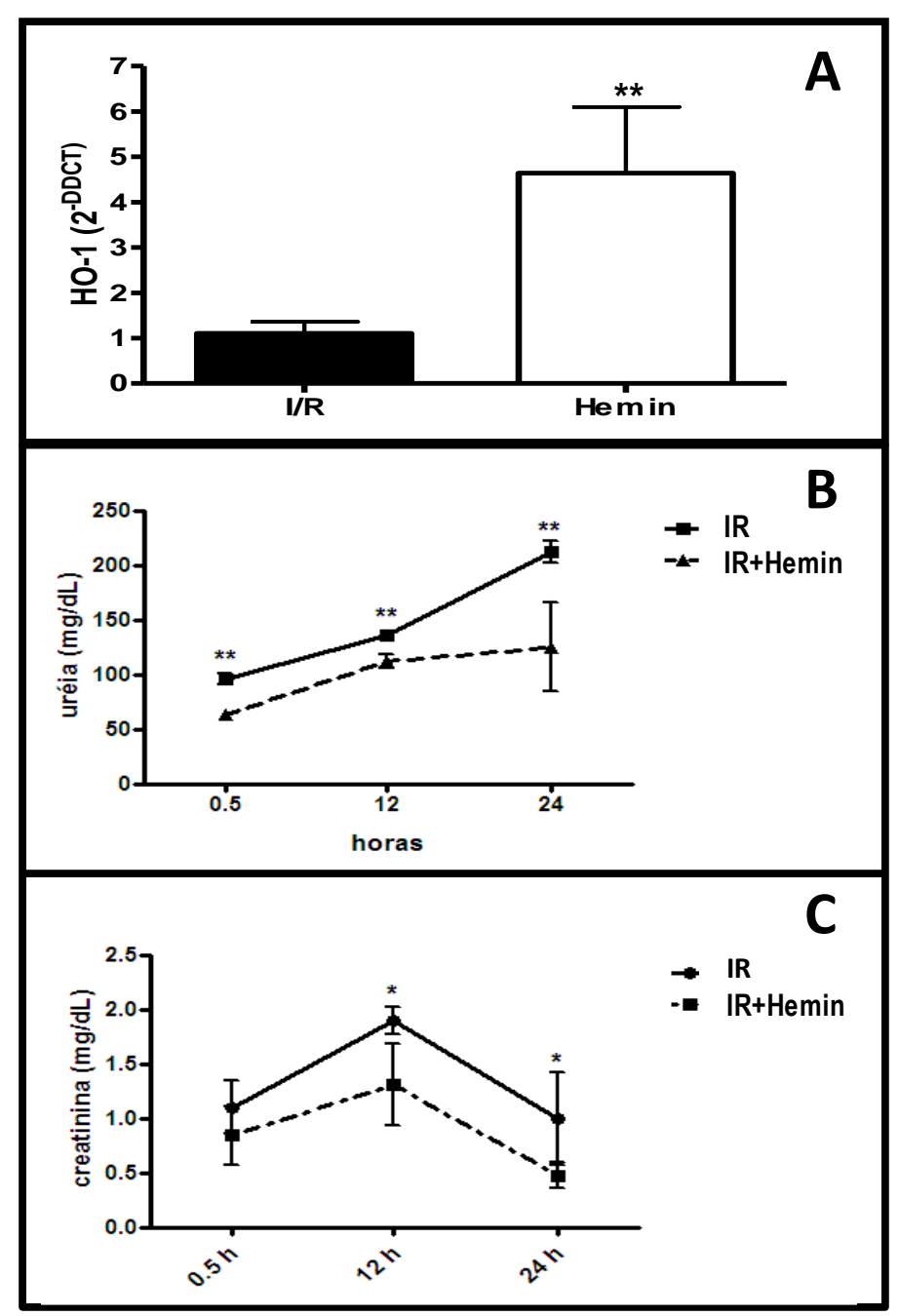

Figura 2. Animais tratados com Hemin apresentam maior expressão de $\mathrm{HO}-1$ e menor lesão renal induzida por IR. A) Animais C57BI6 foram submetidos a IR previamente tratados (Hemin) ou não (I/R) com Hemin e a expressão de HO-1 foi analisada por RT-PCR quantitativo. A lesão renal de animais tratados ou não com Hemin foi analisada pela concentração de uréia (B) e creatinina $(\mathbf{C})$ sérica em 3 momentos $(\mathbf{0 , 5} ; 12$ e 24 horas de reperfusão). $\boldsymbol{n}=$ 5 animais por grupo. ${ }^{* *} \mathrm{P}<0,01 ;{ }^{*} \mathrm{P}<0,05$

Estes resultados corroboram os dados da literatura e confirmam a proteção induzida por HO-1 no modelo de IR renal.

Também analisamos fatores quimiotáticos no soro, que são substâncias capazes de atrair certas células para o local da inflamação. Observamos que em um momento inicial da lesão, há menor concentração de RANTES (Figura 3 A), fator quimiotático para linfócitos $T$, no soro dos animais tratados com Hemin e mais tardiamente, este mesmo grupo apresenta menor concentração de um 
fator quimiotático para monócitos: MCP-1 (Figura $3 \mathrm{~B}$ ), indicando uma menor atração de células como linfócitos $T$ e monócitos para o local da lesão. Além disso, MCP-1 é considerado um marcador de lesão renal aguda, o que mais uma vez confirma a proteção induzida por HO-1.

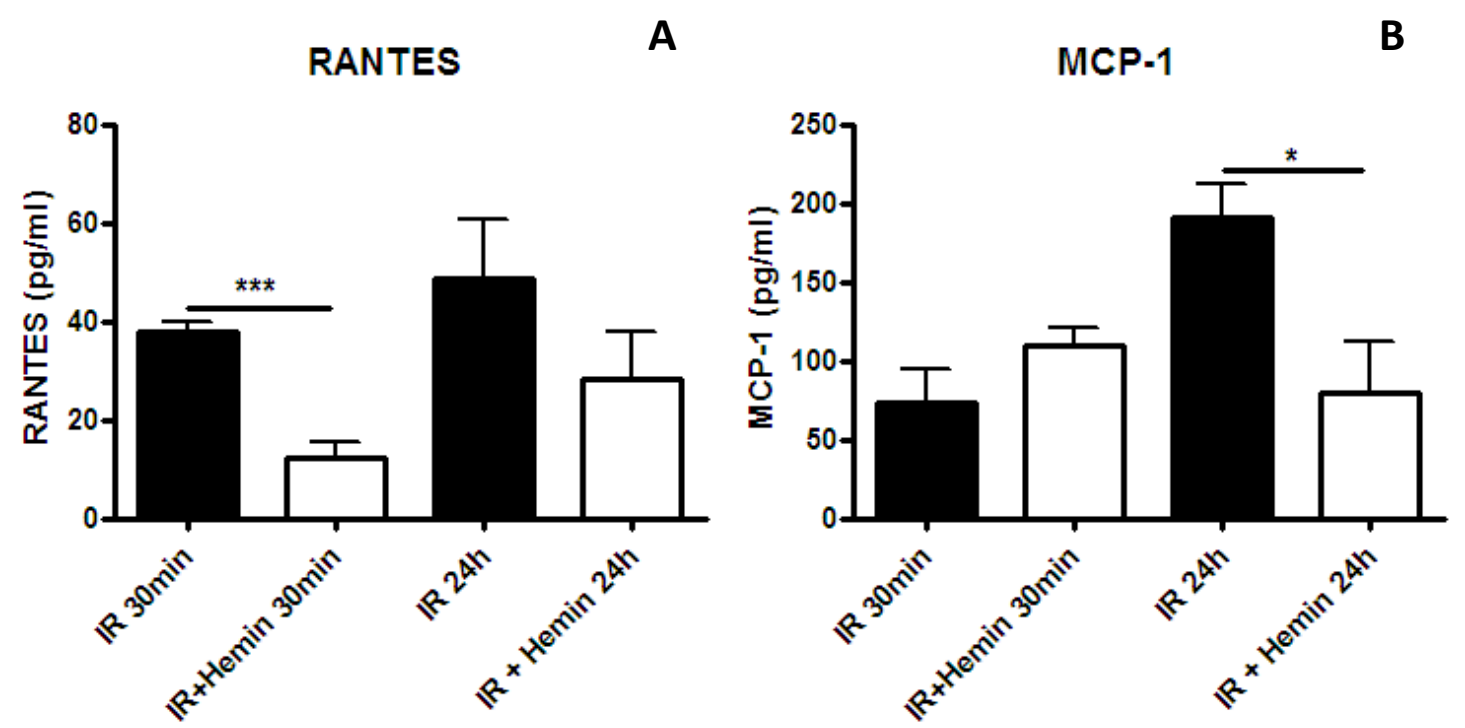

Figura 3. Menor concentração de quimiocinas em animais tratados com Hemin. A) Animais C57Bl6 submetidos a IR previamente tratados com Hemin, apresentaram menor concentração de RANTES em 30 min de reperfusão. B) O mesmo tratamento levou à menor concentração sérica de MCP-1 em $24 \mathrm{~h}$ de reperfusão. $\boldsymbol{n}=5$ animais por grupo. ${ }^{*} \mathrm{P}<0,05 ;{ }^{* \star *} \mathrm{P}<0,001$.

\subsection{A participação de linfócitos $\mathrm{T} \mathrm{CD4}{ }^{+}$na IR}

Para verificar se as células da resposta imune adaptativa faziam parte deste mecanismo de proteção, verificamos inicialmente o papel de linfócitos $T$ $\mathrm{CD}^{+}$no desenvolvimento da lesão. Como descrito na literatura [45], observamos que animais nude, que são animais deficientes de linfócitos $T$ $\mathrm{CD}^{+}$e $\mathrm{T} \mathrm{CD} 8^{+}$, eram protegidos da lesão renal induzida por isquemia e reperfusão de $24 \mathrm{~h}$ (Figura 4). 
A

B
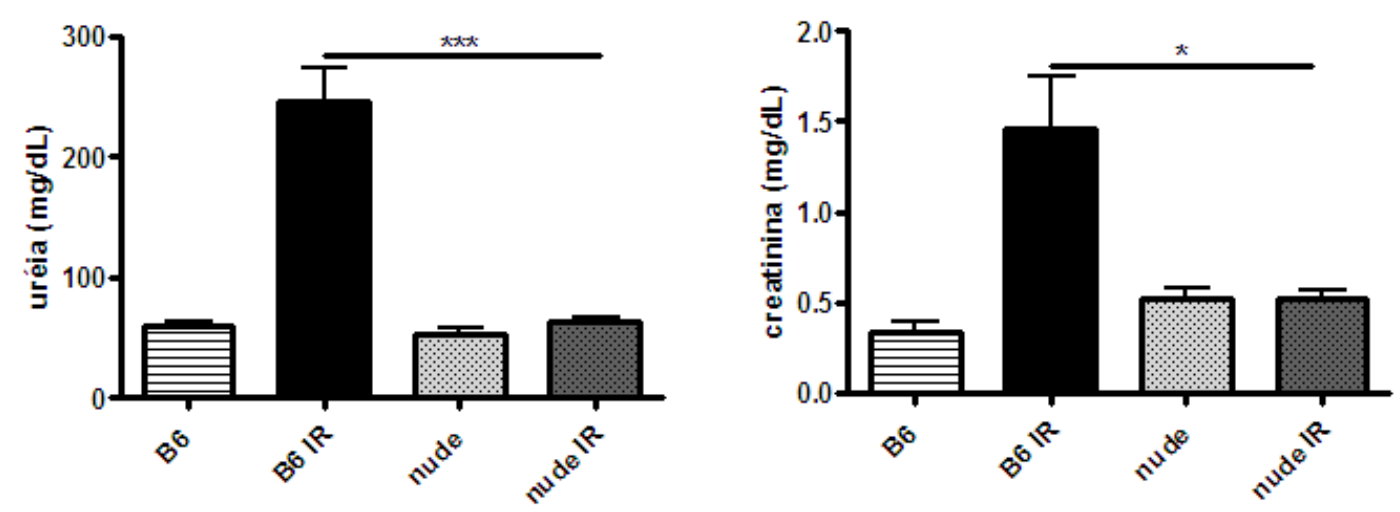

Figura 4. Animais nude são protegidos da lesão renal induzida por IR. Animais nude apresentaram menor lesão renal pela análise de concentração de uréia $(\mathbf{A})$ e creatinina (B) séricas. $\boldsymbol{n}=4$ animais por cada grupo sham e 8 animais por cada grupo IR. ${ }^{*} \mathrm{P}<0,05 ;{ }^{* \star *} \mathrm{P}<0,001$.

Para confirmar os resultados acima, analisamos a resposta à isquemia em outras linhagens de animais deficientes de linfócitos T. Utilizando animais SCID, que são deficientes de linfócitos B e T, e animais deficientes da molécula de $\mathrm{MHC}$ classe II que, portanto, não apresentam linfócitos T CD4 ${ }^{+}$. Ambos apresentaram proteção frente à lesão por IR, como mostra a figura 5. 


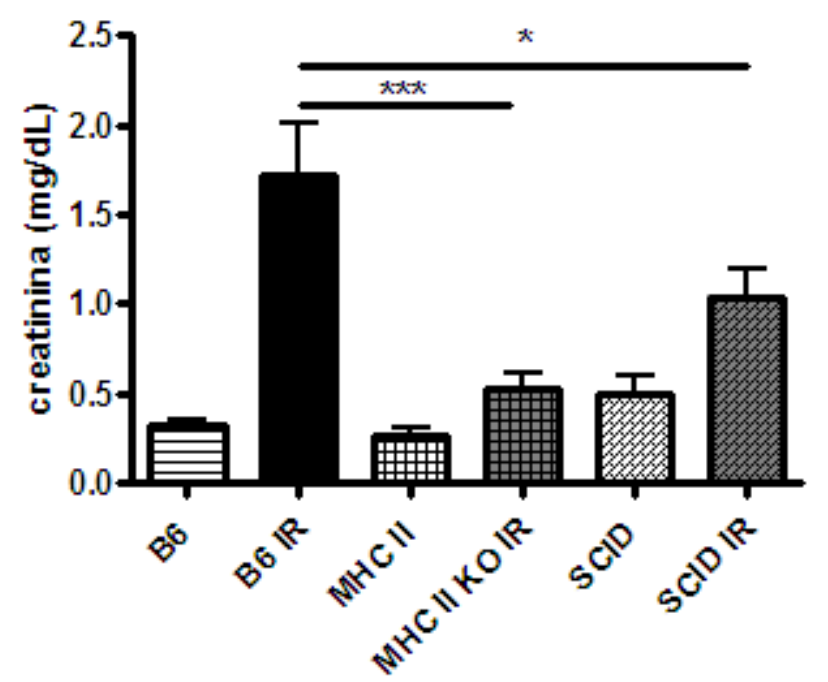

Figura 5. Animais MHC II KO e SCID são protegidos da lesão por IR. Animais MHC de classe II KO (MHC II KO) e SCID apresentaram concentração sérica de creatinina semelhante a animais $\mathrm{C} 57 \mathrm{BI} 6$ controle, indicando proteção da lesão renal após IR. $\boldsymbol{n}=9$ animais por grupo. ${ }^{*} \mathrm{P}<0,05 ;{ }^{* *} \mathrm{P}<0,001$.

Estes dados somados aos da literatura, confirmam que linfócitos T CD4 ${ }^{+}$ apresentam um papel no desenvolvimento da lesão por IR.

\subsection{O efeito da HO-1 na ativação de linfócitos T CD4+}

Uma vez que linfócitos T CD4 ${ }^{+}$contribuem para a lesão por IR e esta lesão pode ser amenizada com a indução de HO-1, perguntamo-nos se esta proteção seria via inibição da ativação de linfócitos T CD4 ${ }^{+}$. Para tanto, começamos com um experimento in vitro no qual utilizamos esplenócitos provenientes de um animal da linhagem OTII que apresentam TCR específico para OVA. Marcamos estas células com CFSE e cultivamos por 4 dias em presença do peptídeo OVA com ou sem adição de Hemin ao meio de cultura. A proliferação celular foi analisada por citometria de fluxo avaliando apenas a população $\mathrm{CD}^{+}$. Conforme mostra a figura 6 , o tratamento com Hemin inibiu a proliferação celular. 


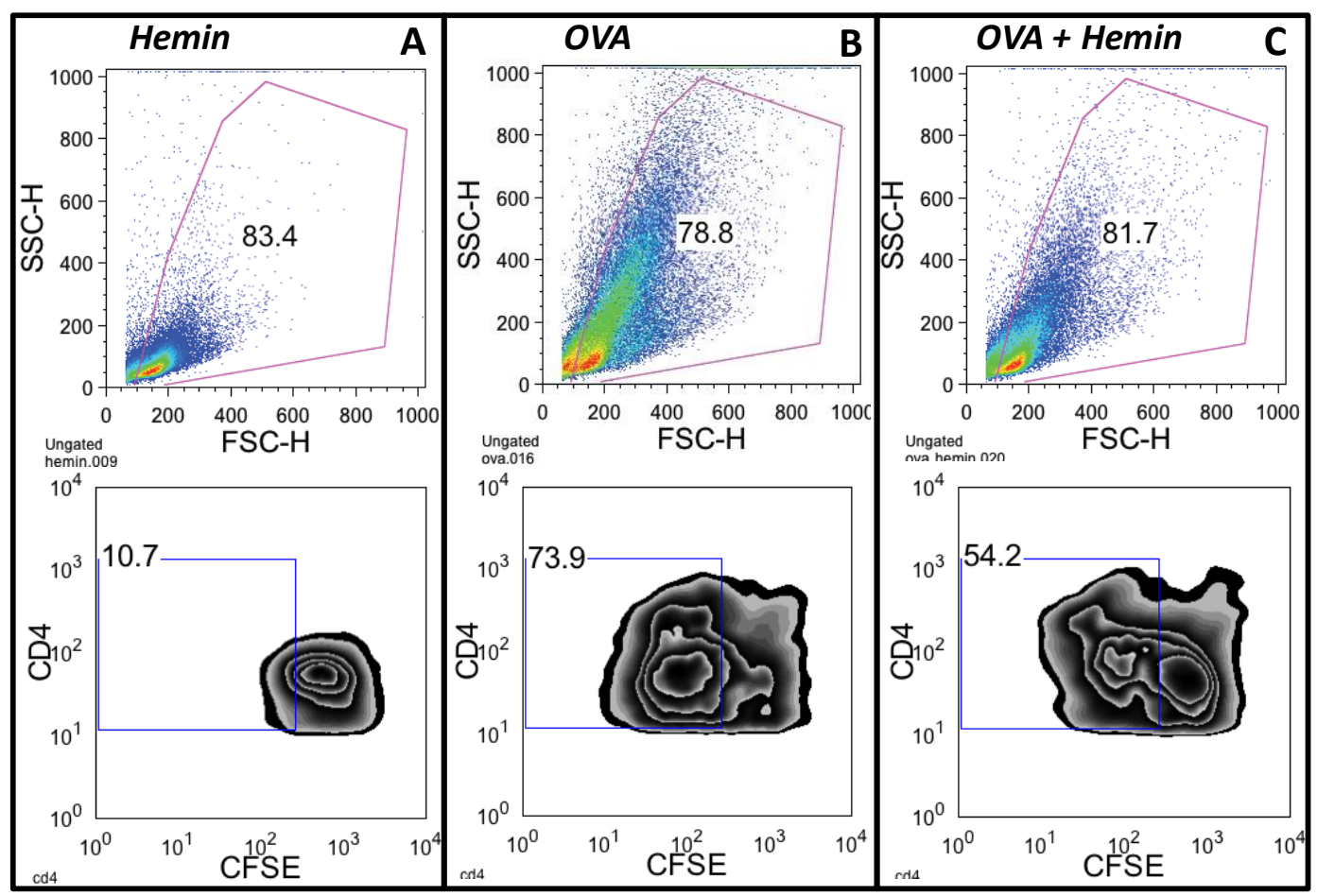

Figura 6. Hemin inibiu a proliferação de linfócitos $T$ CD4. A proliferação celular foi analisada pelo decaimento da marcação de CFSE dos esplenócitos OTII dentro da população CD4 positiva nos grupos que receberam o peptídeo (OVA) específico para o TCR das células utilizadas, na presença (C) ou ausência (B) do tratamento com Hemin. Como controle, mantivemos células na ausência do peptídeo na presença do Hemin (A). As figuras na parte superior representam a população que foi selecionada para a análise das figuras inferiores. As figuras são representativas de 3 experimentos.

Como a menor proliferação muitas vezes pode ser explicada pelo aumento da morte celular, fizemos um experimento para verificar a viabilidade das células nas condições do ensaio de proliferação. Neste caso, não marcamos as células com CFSE e fizemos apenas a marcação com iodeto de propídeo e anexina V. Consideramos mortas tanto as duplas marcações como as simples marcações de cada um deles. Desta forma, foram consideradas vivas as células não marcadas. A figura 7 mostra que o tratamento com Hemin em diferentes concentrações não alterou a viabilidade das células. $O$ tratamento com actimicina A (AMA), um inibidor de transporte de elétrons na mitocôndria, foi utilizado como controle positivo de morte celular. 


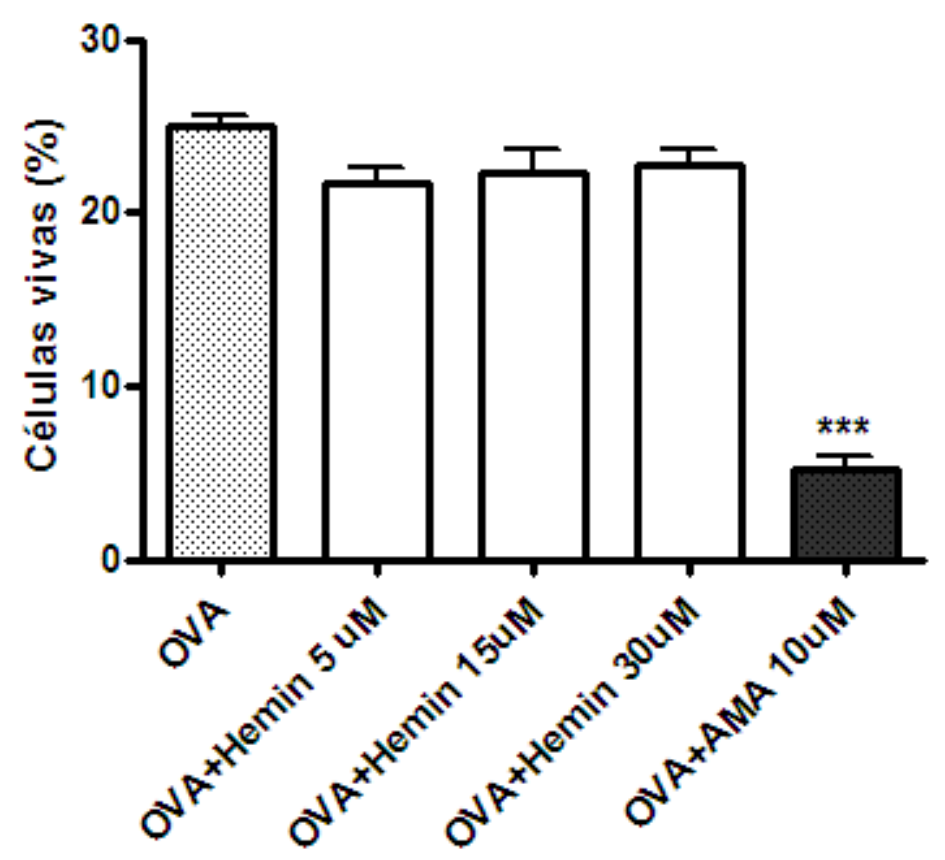

Figura 7. Tratamento com Hemin não altera a viabilidade celular. Para verificar se o tratamento com Hemin estaria levando as células à morte celular, utilizamos esplenócitos de animais OTII e ativamos na presença do peptídeo OVA e após 5 dias de cultura, analisamos por citometria de fluxo a marcação de morte celular (iodeto de propídeo e anexina V) e consideramos vivas as células não marcadas. Foram utilizadas 3 concentrações de Hemin (5, 15 e $30 \mathrm{uM}$ ) e como controle positivo de morte utilizamos actimicina A (AMA). ${ }^{* * *} \mathrm{P}<0,001$.

Assim, seguimos para o modelo in vivo, e analisamos os linfócitos dos linfonodos peri-renais. Utilizamos o mesmo protocolo de tratamento com Hemin descrito e coletamos os linfonodos com 30 minutos ou $24 \mathrm{~h}$ de reperfusão. Analisando fenótipos de ativação de linfócitos T CD4+ (CD69 e CD25), não observamos nenhuma diferença entre os grupos tratado e não tratado (Figura 8). No entanto, observamos uma queda na ativação de linfócitos no decorrer do desenvolvimento da lesão. 

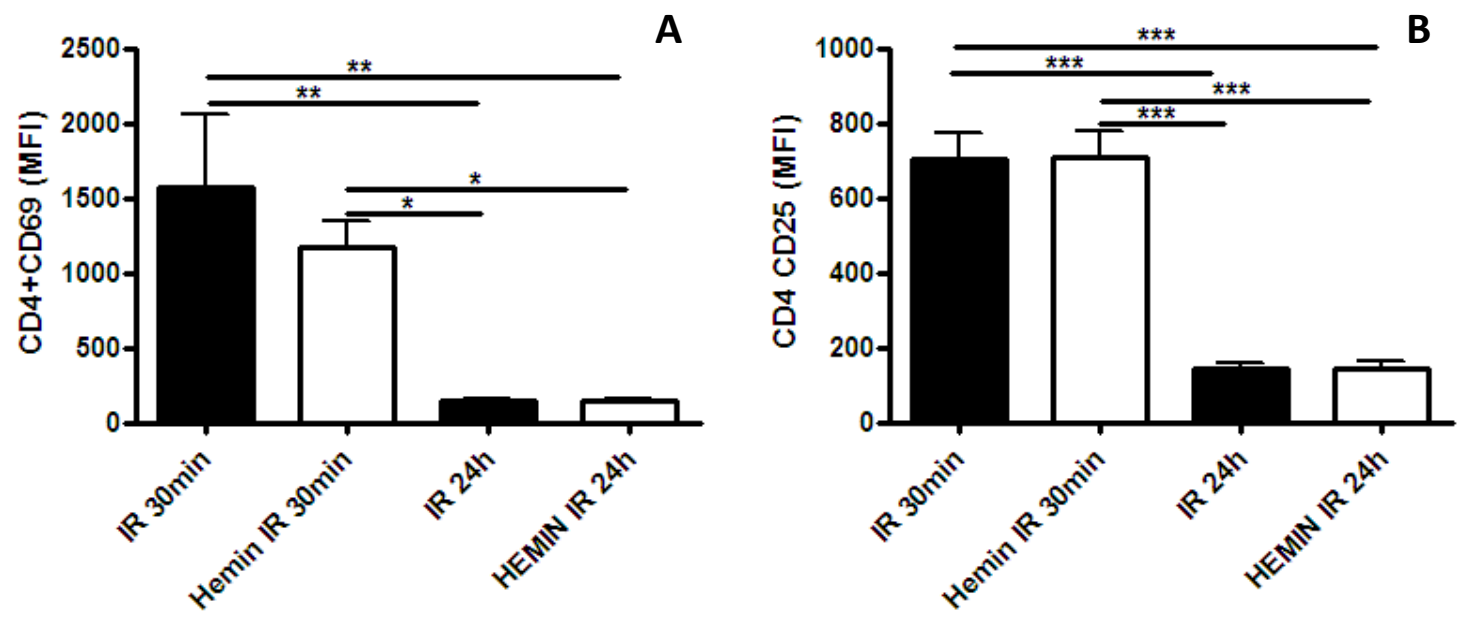

Figura 8. Hemin não altera o fenótipo de ativação de linfócitos T CD4 do linfonodo renal. Analisamos a ativação de linfócitos T CD4 pela presença das moléculas CD69 (A) e CD25 (B) nos grupos tratados (branco) ou não (preto) com Hemin. Dois tempos de reperfusão foram analisados: 30 min e 24 h. ${ }^{*} \mathrm{P}<0,05$; ${ }^{* *} \mathrm{P}<0,01 ;{ }^{* *} \mathrm{P}<0,001$.

Uma vez que não observamos nenhuma diferença na ativação dos linfócitos $\mathrm{T} \mathrm{CD4}^{+}$, decidimos verificar se a proteção induzida pela $\mathrm{HO}-1$ não seria por um aumento de linfócitos reguladores. Para isto, analisamos por RTPCR em tempo real a expressão gênica do fator de transcrição Foxp3, que está fortemente associada à função reguladora da célula. Também analisamos por citometria de fluxo a população de células Foxp3 positivas dentro de CD4 e CD25 positivas. Em ambas as análises, não foram observadas diferenças significantes (Figura 9). 

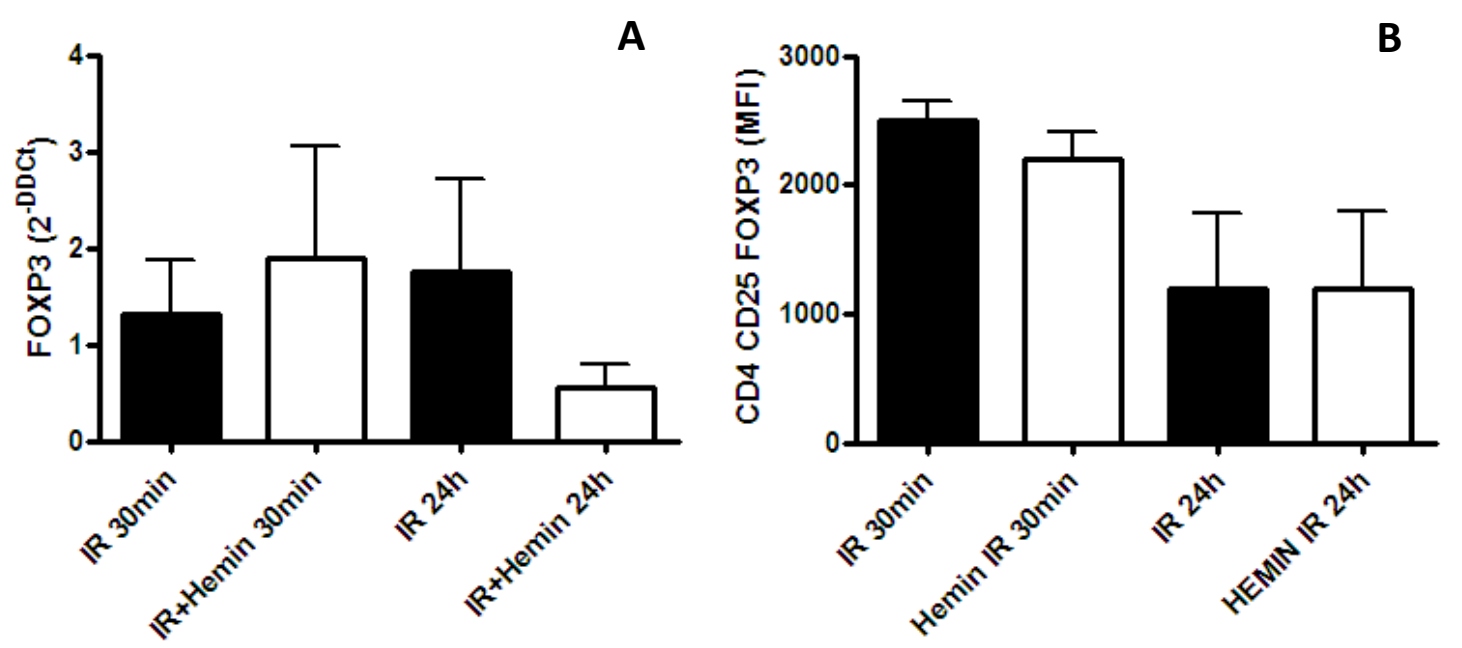

Figura 9. Tratamento com Hemin não altera a presença de Tregs no linfonodo renal. A) Analisamos a expressão de Foxp3 no linfonodo renal por RT-PCR em tempo real e B) Utilizamos a citometria de fluxo para analisar a presença de Foxp3 em linfócitos $\mathrm{CD} 4^{+} \mathrm{CD} 25^{+}$nos linfonodos renais, nenhuma diferença entre os grupos tratado (branco) e não tratado (preto) com hemin foi observada. As análises foram feitas em dois tempos de reperfusão: 30 min e $24 \mathrm{~h}$.

Como nenhuma diferença foi observada nos fenótipos de linfócitos $T$ $\mathrm{CD}^{+}$entre os grupos tratado e não com Hemin, decidimos analisar a produção de citocinas relacionadas à ativação de linfócitos $\mathrm{T} \mathrm{CD4}^{+}$. Analisando a expressão gênica das citocinas IFNg e IL-2, que são associadas à ativação de linfócitos $\mathrm{T} \mathrm{CD4}^{+}$, observamos uma tendência à menor expressão de ambas no linfonodo do grupo tratado com Hemin. Já a análise de proteínas no tecido renal não apresentou diferença nenhuma entre os grupos. Porém, ao analisarmos a concentração de IFNg no soro dos animais, observamos uma maior concentração de IFNg nos animais não tratados com Hemin, indicando um possível papel dos linfócitos na proteção induzida pela HO-1 (Figura 10). 

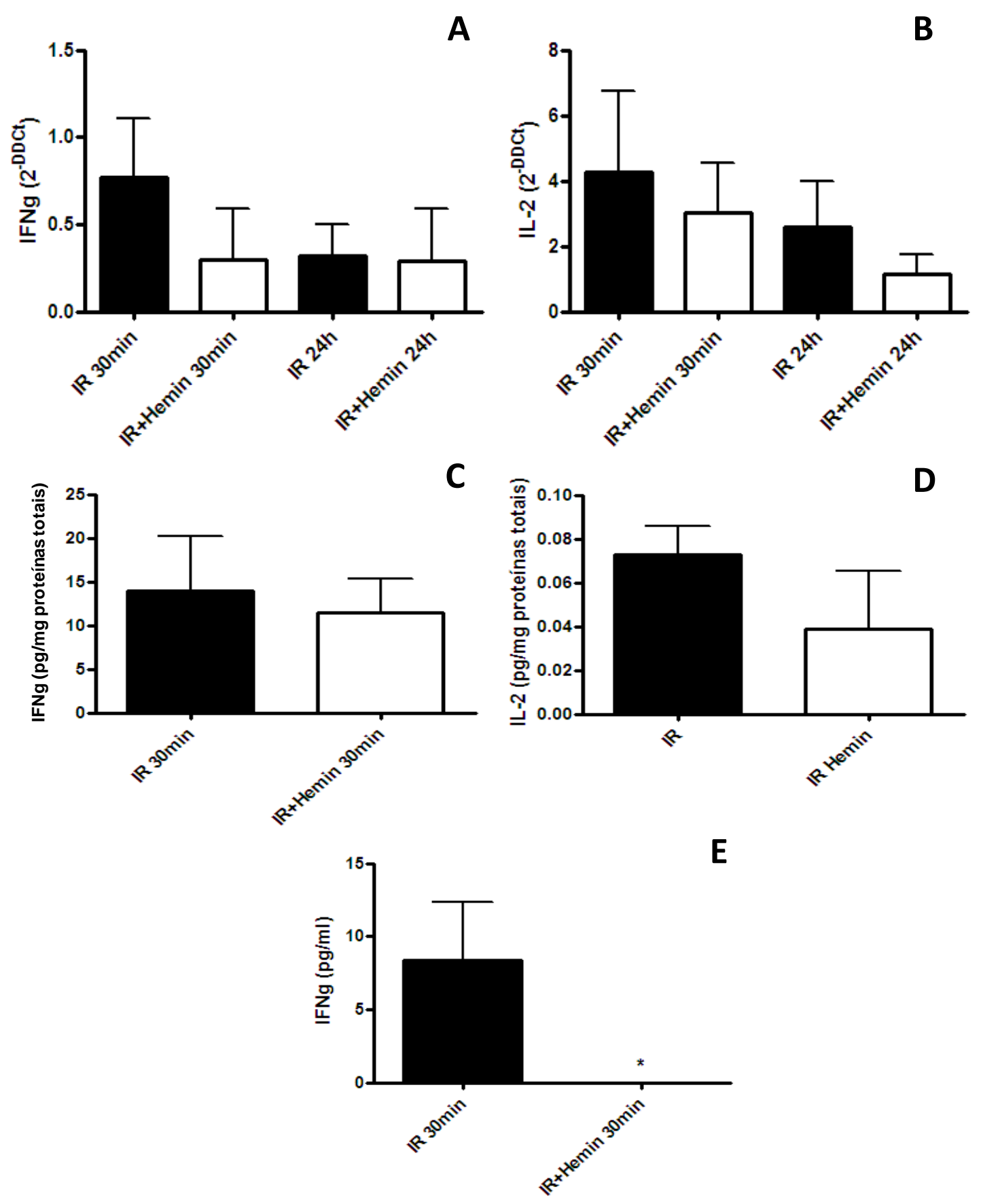

Figura 10. Citocinas produzidas por linfócitos $T$ ativados são diminuídas com 0 tratamento de Hemin. Analisamos a expressão de IFNg (A) e de IL-2 (B) no linfonodo renal por RT-PCR em tempo real e quantificamos ambas as citocinas por bioplex no tecido renal (C e $\mathbf{D}$, respectivamente). Também por bioplex, dosamos a concentração de IFNg no soro dos animais tratados (branco) ou não (preto) ou com Hemin. ${ }^{*} \mathrm{P}<0,05$. 
Estes resultados indicam que a HO-1 possa estar modulando linfócitos $\mathrm{T}$ funcionalmente, levando à proteção da lesão.

\subsection{A transferência de esplenócitos tratados com Hemin confere proteção}

Como linfócitos $\mathrm{T}^{\mathrm{CD}^{+}}$não parecem estar envolvidos com 0 desenvolvimento da lesão por IR, enquanto linfócitos $T C D 4^{+}$são fundamentais para a injúria renal neste modelo [45], decidimos estudar mais a fundo se a proteção induzida pela HO-1 seria decorrente da modulação de linfócitos $\mathrm{T}$ $\mathrm{CD}^{+}$. Para isto, utilizamos esplenócitos de animais CD8 KO, que apresentam uma proporção maior de linfócitos T CD4, previamente tratados ou não com hemin e fizemos a transferência adotiva destes esplenócitos em animais deficientes da molécula de MHC de classe II (MHC II KO) que, portanto são CD4 deficientes. Após $24 \mathrm{~h}$ da transferência, realizamos a IR e observamos que os animais que receberam esplenócitos de animais tratados com Hemin eram protegidos em relação a animais que não receberam o tratamento, como mostra a figura 11. 


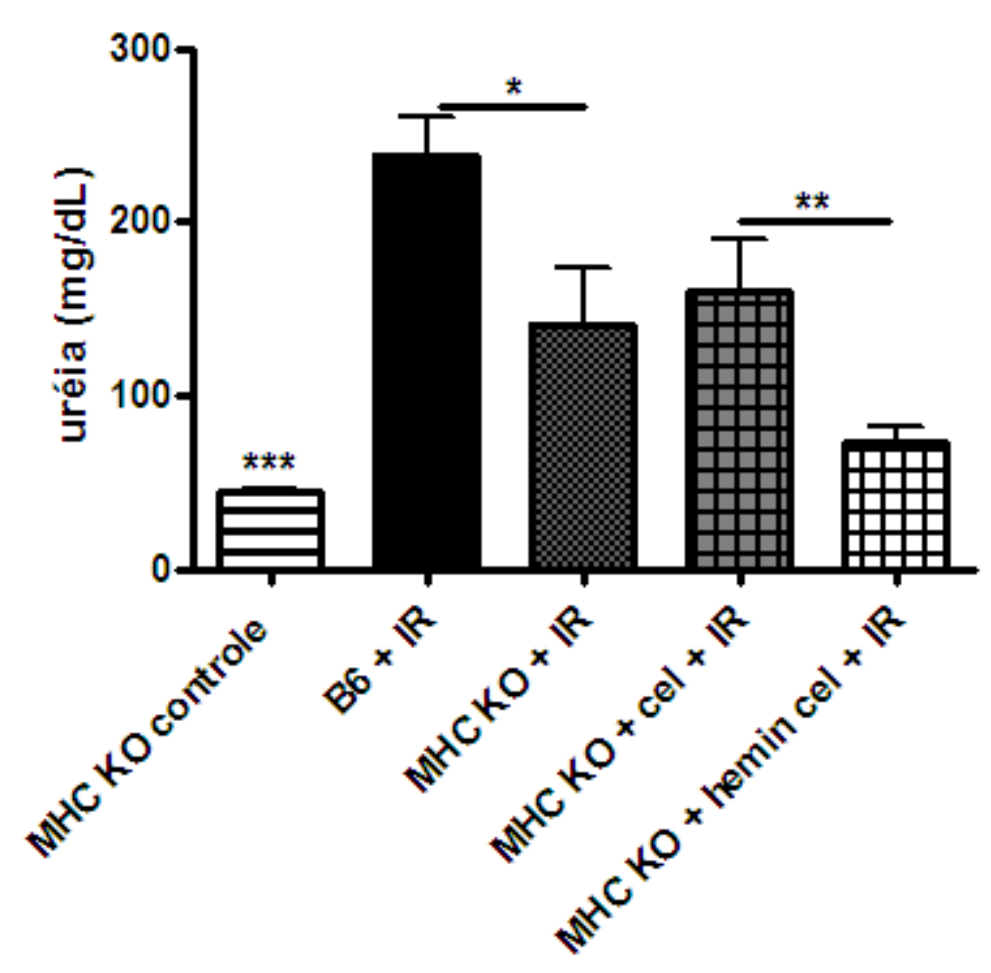

Figura 11. Transferência adotiva de esplenócitos tratados com Hemin protege animais da lesão pro IR. Animais deficientes de linfócitos T CD4 (MHC II KO) receberam esplenócitos de animais que previamente tratados (barra branca) ou não (barra preta) com Hemin e foram submetidos à IR. Animais que não receberam células foram utilizados como controles com (MHC II KO IR) e sem cirurgia (MHC II KO controle). Animais da linhagem C57BI6 (B6+IR) foram usados como controle positivo de lesão. $\boldsymbol{n}=10$ por grupo. ${ }^{*} \mathrm{P}<0,05$.

Observada a proteção após a transferência de esplenócitos tratados com Hemin, decidimos analisar o perfil dos linfócitos T CD4 ${ }^{+}$nestes animais. Nenhuma diferença foi observada quanto à ativação (Figura 12 A e B). No entanto, observamos uma maior concentração de linfócitos $T$ reguladores $\left(\mathrm{CD}^{+} \mathrm{CD}^{+} 5^{+} \mathrm{FOXP3}^{+}\right)$no linfonodo renal dos animais que receberam as células de animais tratados com hemin (Figura $12 \mathrm{C}$ ). 


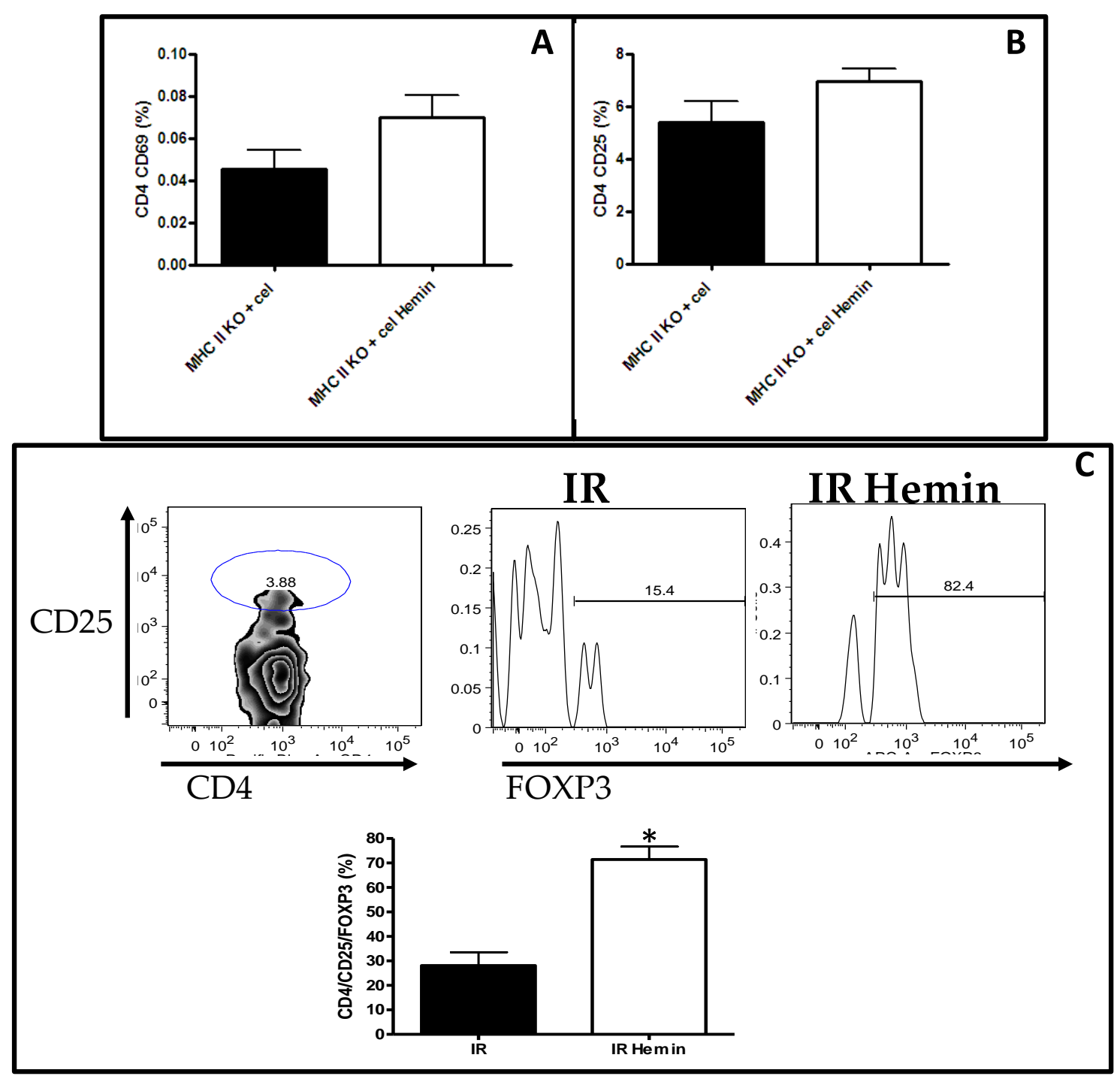

Figura 12. Transferência adotiva de esplenócitos tratados com Hemin aumenta a freqüência de Tregs. Animais deficientes de linfócitos T CD4 (MHC II KO) receberam esplenócitos de animais que previamente tratados (barra branca) ou não (barra preta) com Hemin e foram submetidos à IR. O fenótipo de ativação de linfócitos T CD4 foi analisado pela expressão das moléculas de superfície CD69 (A) e CD25 (B) por citometria de fluxo. A presença de Tregs também foi analisada por citometria de fluxo pela freqüência de FOXP3 nas células $\mathrm{CD}^{+}{ }^{+} \mathrm{CD} 25^{+}(\mathbf{C}) . \boldsymbol{n}=10$ por grupo. ${ }^{*} \mathrm{P}<0,05$. 
Como observamos a proteção nos animais que receberam esplenócitos de animais previamente tratados com Hemin, analisamos também o perfil de algumas citocinas no soro destes animais. Embora uma tendência à menor concentração de TNF-a (Figura 13 A) e maior de IL-10 (Figura 13 B) nos animais que receberam células dos animais tratados com hemin, nenhuma diferença estatística foi observada, bem como os níveis séricos de IL-12 (Figura 13 D). Além disso, IFN-g não apresentou a mesma diferença observada nos animais C57Bl6 que receberam Hemin diretamente (Figura 13 C)
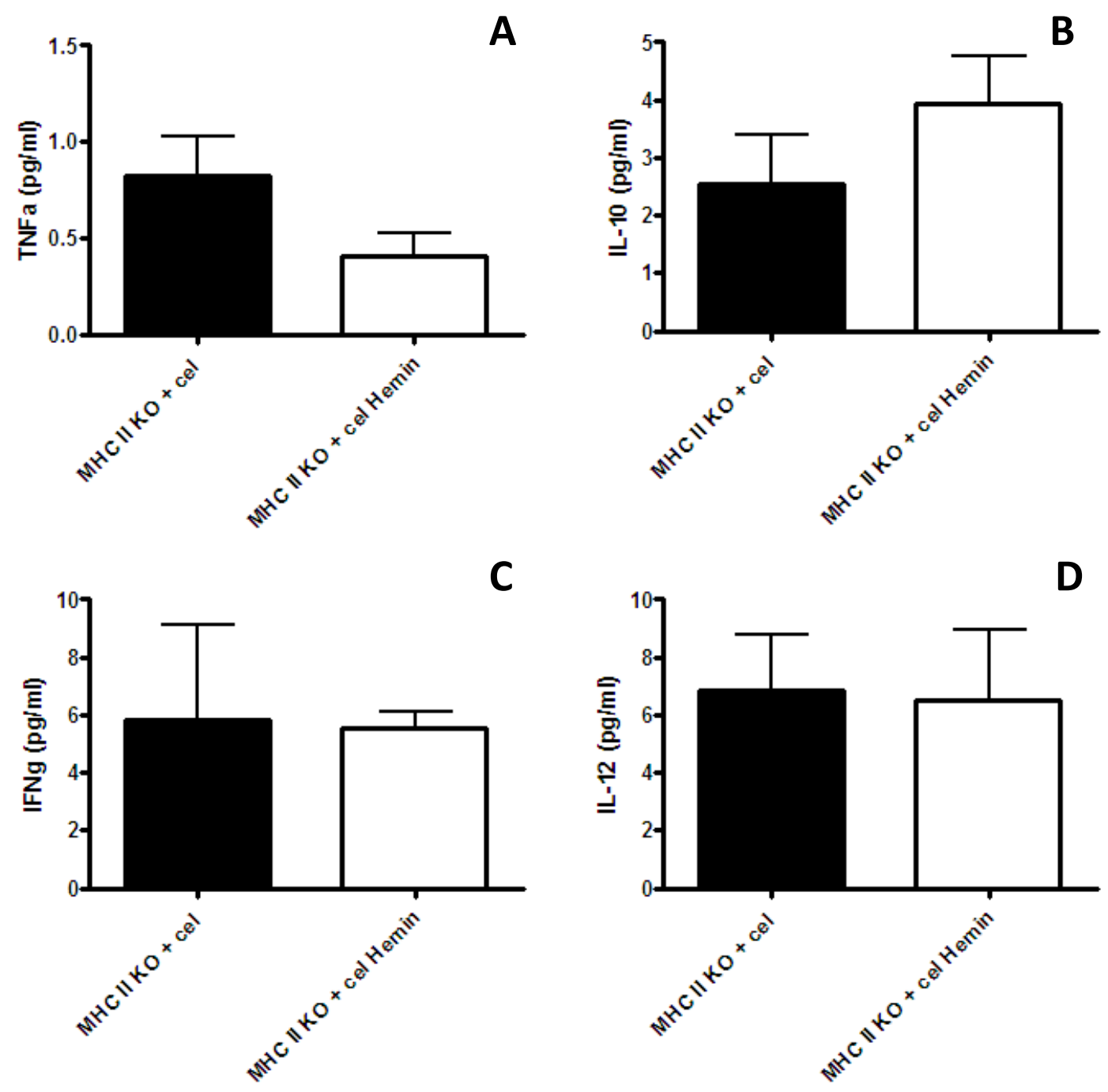

Figura 13. Transferência adotiva de esplenócitos tratados com Hemin não alterou os níveis séricos de citocinas. Animais MHC II KO receberam esplenócitos de animais que previamente tratados (barra branca) ou não (barra preta) com Hemin e foram submetidos à IR. As concentrações séricas de citocinas foram analisadas por bioplex. Nenhuma diferença foi observada nos níveis de A) TNFa, B) IL-10, C) IFNg e D) IL-12. 
Estes resultados corroboram a idéia de que a HO-1 possa estar modulando linfócitos $\mathrm{T} \mathrm{CD4}^{+}$, para um perfil regulatório, no entanto, a transferência de esplenócitos não exclui a possibilidade de outras células estarem envolvidas nesta proteção.

\subsection{A transferência de linfócitos $\mathrm{T} \mathrm{CD4}^{+}$tratados com Hemin não confere proteção}

Para ter a certeza de que os linfócitos $\mathrm{T} \mathrm{CD4}{ }^{+}$eram os protagonistas da proteção da lesão por IR induzida pela HO-1, utilizamos animais C57BI6 tratados ou não com Hemin e separamos as células $\mathrm{CD}^{+}$por beads. Transferimos as células purificadas em animais MHC II KO e realizamos a isquemia nos mesmos. Surpreendentemente, animais que receberam células de animais não tratados com Hemin, apresentaram proteção, bem como animais que receberam células tratadas com Hemin, como observado na figura 14.

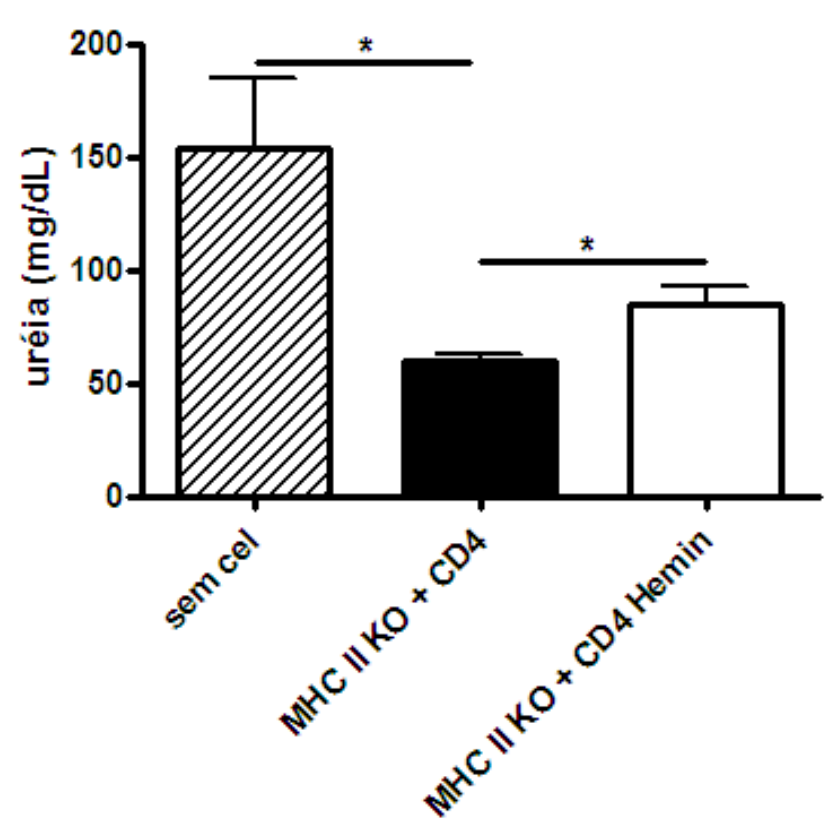

Figura 14. Transferência adotiva de células $C D 4^{+}$tratadas com Hemin não protegem mais do que células não tratadas. MHC II KO receberam células $\mathrm{CD} 4^{+}$de animais tratados (barra branca) ou não (barra preta) com Hemin e foram submetidos à IR. Animais que não receberam células foram utilizados como controles (sem cel). $\boldsymbol{n}=5$ por grupo. ${ }^{*} \mathrm{P}<0,05$. 
Assim, vimos que o tratamento com Hemin não altera linfócitos T CD4+ para um perfil protetor na ausência de outras células durante 0 desenvolvimento da lesão. Este resultado foi confirmado pelo perfil dos linfócitos $\mathrm{T} \mathrm{CD4}^{+}$após a IR, onde não houve diferença no fenótipo de ativação entre os grupos, e até uma menor proporção de Tregs nos animais que receberam células de doadores tratados com Hemin (Figura 15).

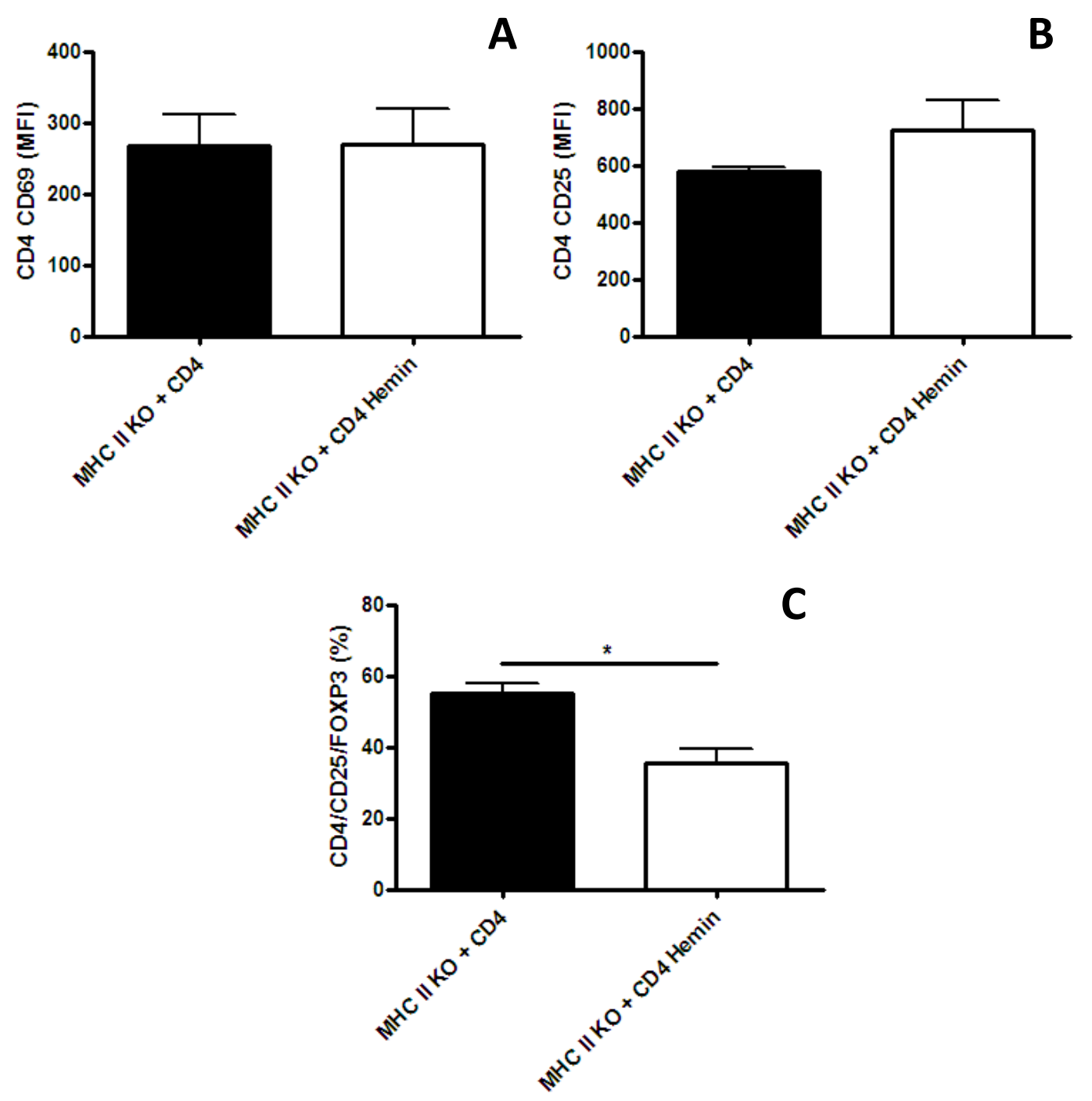

Figura 15. Transferência adotiva de células $C D 4^{+}$tratadas com Hemin levou a uma menor proporção de Tregs no linfonodo renal. MHC II KO receberam células $\mathrm{CD}^{+}$de animais tratados (barra branca) ou não (barra preta) com Hemin e foram submetidos à IR. $O$ fenótipo de ativação foi analisado pela expressão das moléculas CD69 (A) e CD25 (B) nas células CD4 $4^{+}$por FACS. A presença de Tregs também foi analisada por citometria de fluxo pela freqüência de FOXP3 nas células $\mathrm{CD}^{+} \mathrm{CD} 25^{+}(\mathbf{C}) . \boldsymbol{n}=5$ por grupo. ${ }^{*} \mathrm{P}<0,05$. 
Como não detectamos IL-2 e IFN-g no soro destes animais, analisamos o perfil das citocinas TNF-a e IL-10, que também não mostrou nenhuma diferença entre os grupos como mostra a figura 16.

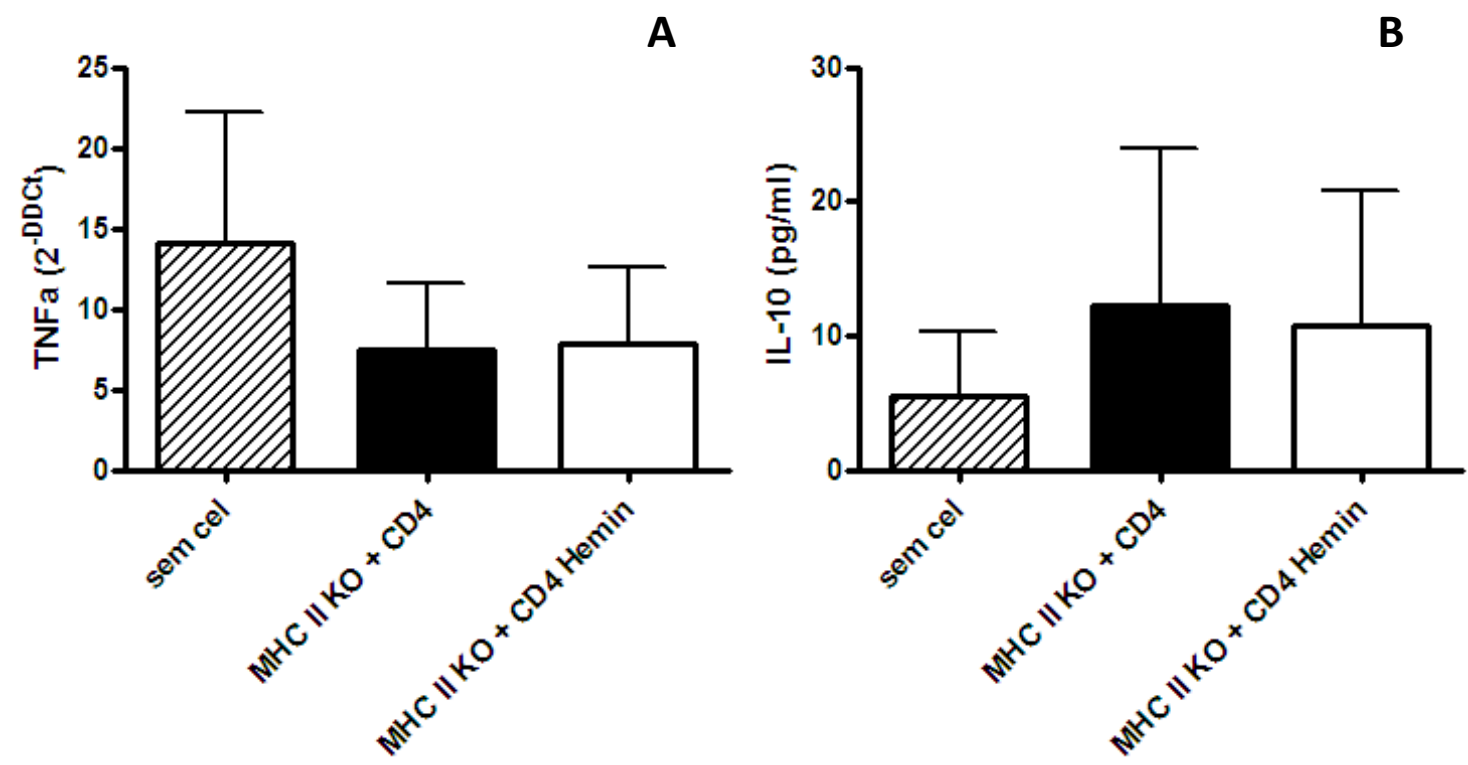

Figura 16. Transferência de células $C D 4^{+}$tratadas com Hemin não alterou a expressão de TNFa e IL-10 após IR. MHC II KO receberam células CD4 ${ }^{+}$de animais tratados (barra branca) ou não (barra preta) com Hemin e foram submetidos à IR. Animais que não receberam células foram utilizados como controles (sem cel). Níveis de TNFa foram analisados por RT-PCR em tempo real do tecido renal $(\mathbf{A})$. A concentração de IL-10 foi analisada soro dos animais por Bioplex. $\boldsymbol{n}=5$ por grupo. ${ }^{*} \mathrm{P}<0,05$.

Reunindo todos os dados até agora demonstrados, observamos que há uma proteção induzida pela $\mathrm{HO}-1$, transferível quando tratamos animais com Hemin e passamos esplenócitos destes animais para CD4 deficientes. No entanto, a transferência de células $\mathrm{CD}^{+}$previamente tratadas com Hemin, não é suficiente para levar à proteção da lesão por IR. Desta forma, decidimos investigar as células dendríticas, por serem células apresentadoras de antígeno, podendo ativar linfócitos $\mathrm{T} \mathrm{CD}^{+}$, além de serem moduladas por $\mathrm{HO}$ 1 em outros modelos [63]. 


\subsection{Participação de células dendríticas na IR}

Primeiramente, utilizamos um modelo de depleção de fagócitos por adição de lipossomos com clodronato, para verificar se com este protocolo teríamos menos DC e com isso a resposta à isquemia e reperfusão seria mais amena, o que mostraria o envolvimento destas células no desenvolvimento da lesão. Como esperado, o número de DC tanto no baço quanto no rim estava diminuíd'o em relação ao controle (Figura 17). No entanto, os animais que receberam o clodronato apresentaram a mesma lesão que animais não tratados (Figura 18). 


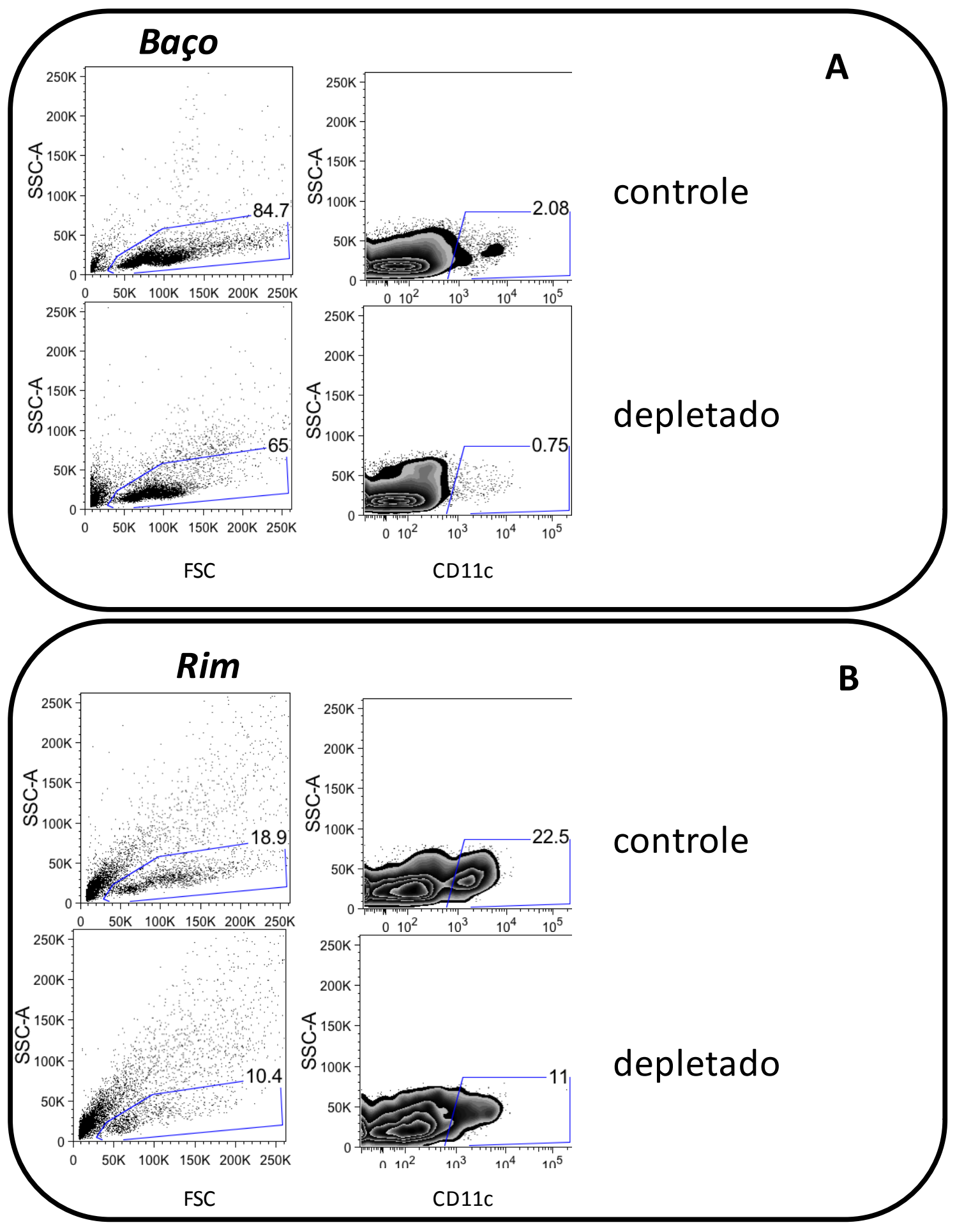

Figura 17. Depleção por clodronato diminui a frequência de $D C$ no baço e no rim. Para depletar fagócitos, utilizamos o método de injeção de lipossomos contendo clodronato como descrito anteriormente. A) Observamos que a frequência

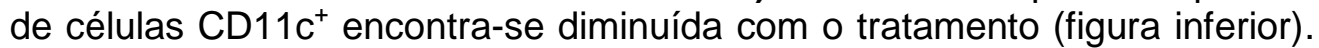
O mesmo fenômeno é observado no (B) rim. Representativo de 5 animais por grupo. 


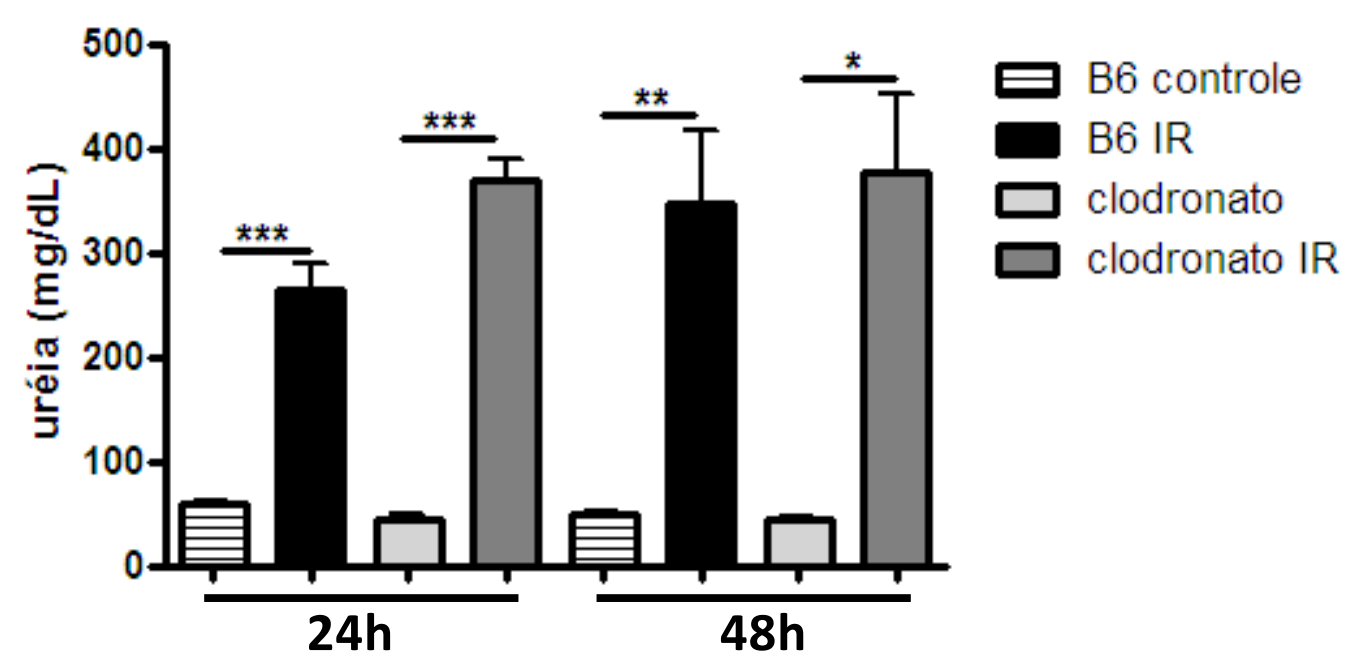

Figura 18. Depleção por clodronato não protege da lesão por IR. Ao depletar animais com clodronato, observamos a mesma diferença entre animais isquemiados e controle que animais não depletados, tanto em $24 \mathrm{~h}$ quanto em $48 \mathrm{~h}$ de reperfusão. Esta análise foi feita pela função renal por níveis de uréia no soro. ${ }^{*} \mathrm{P}<0,05 ;{ }^{* *} \mathrm{P}<0,01 ;{ }^{* *} \mathrm{P}<0,001$.

Também analisamos o fenótipo de DC no rim destes animais, uma vez que a depleção não foi completa. Observamos um aumento de ativação entre 24 e 48h de reperfusão, mas nenhuma diferença foi observada entre o grupo depletado e o grupo não depletado (Figura 19).

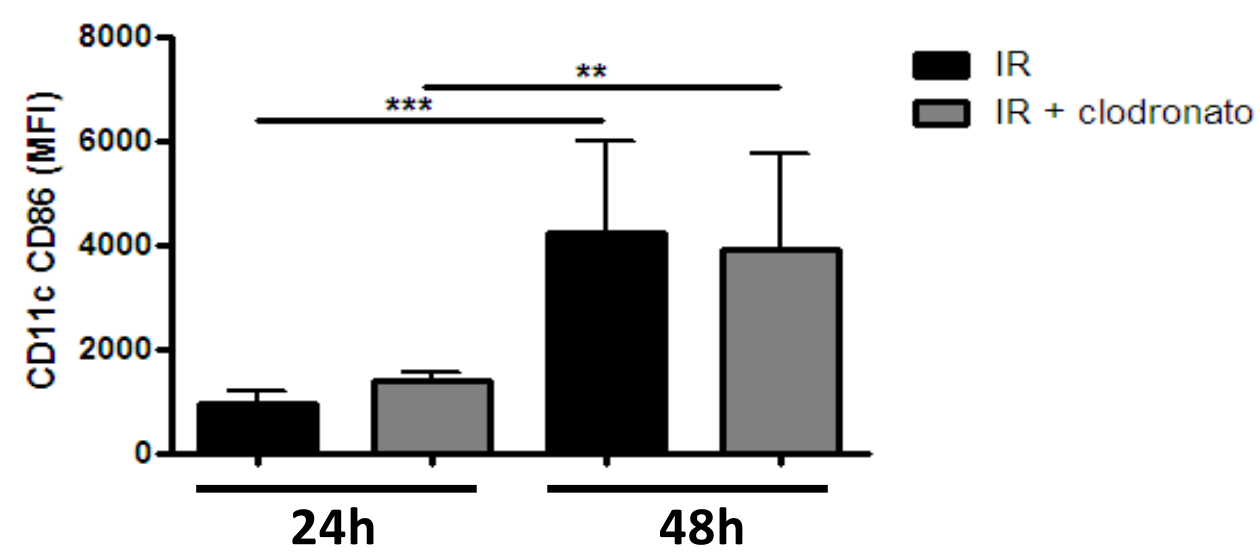

Figura 19. Depleção por clodronato não altera o fenótipo de ativação das $D C$ restantes no rim. Analisamos o perfil de ativação das DC pela expressão da molécula CD86 nas células CD11 ${ }^{+}$. Observamos um aumento de ativação em $48 \mathrm{~h}$ de reperfusão, mas nenhuma diferença entre o grupo depletado e não depletado. ${ }^{* *} \mathrm{P}<0,01 ;{ }^{* *} \mathrm{P}<0,001$. 
Para confirmar estes resultados, utilizamos outro modelo de depleção de células dendríticas, que consiste no uso de animais transgênicos que apresentam o receptor de toxina diftérica no promotor de CD11c, de forma que na presença da toxina, células $\mathrm{CD}_{11 \mathrm{c}^{+}}$são eliminadas. Neste caso, não observamos a mesma eficiência de depleção de DC no baço, no entanto a depleção no rim foi eficiente (Figura 20). 


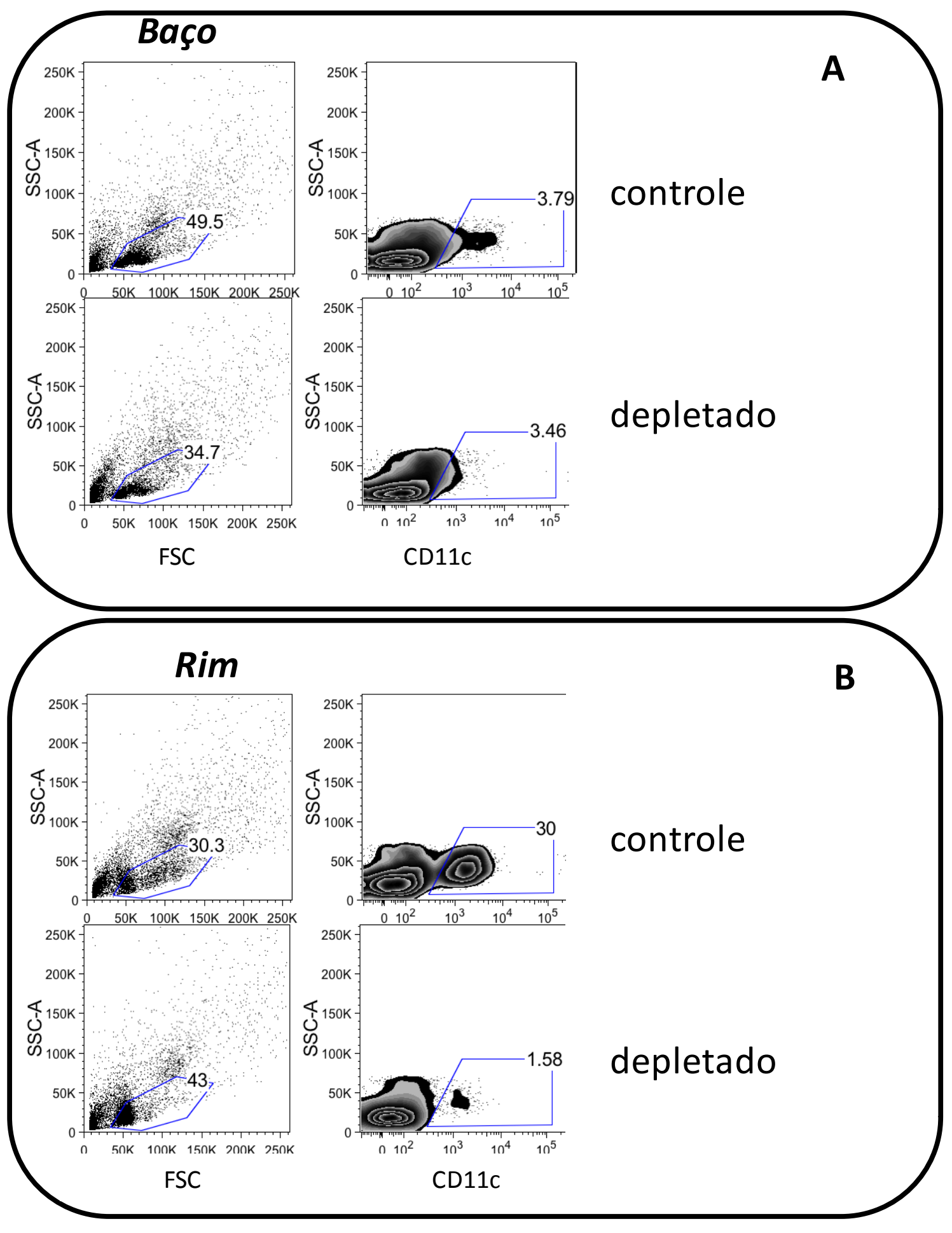

Figura 20. Depleção de $D C$ pela adição da toxina diftérica em animais CD11c-DTR Para depletar DC, utilizamos animais CD11c-DTR e injetamos a toxina diftérica. A) No baço, a depleção não foi eficiente, enquanto que no rim (B) a frequência de células $\mathrm{CD}_{11 \mathrm{c}^{+}}$diminuiu com a toxina (figura inferior). Representativo de 5 animais por grupo. 
Neste modelo, nenhuma diferença na função renal foi observada com 24 h de reperfusão, corroborando com o resultado da depleção por clodronato (Figura 21). No entanto, após $48 \mathrm{~h}$ de reperfusão, os animais depletados apresentaram menor lesão renal (Figura 21).

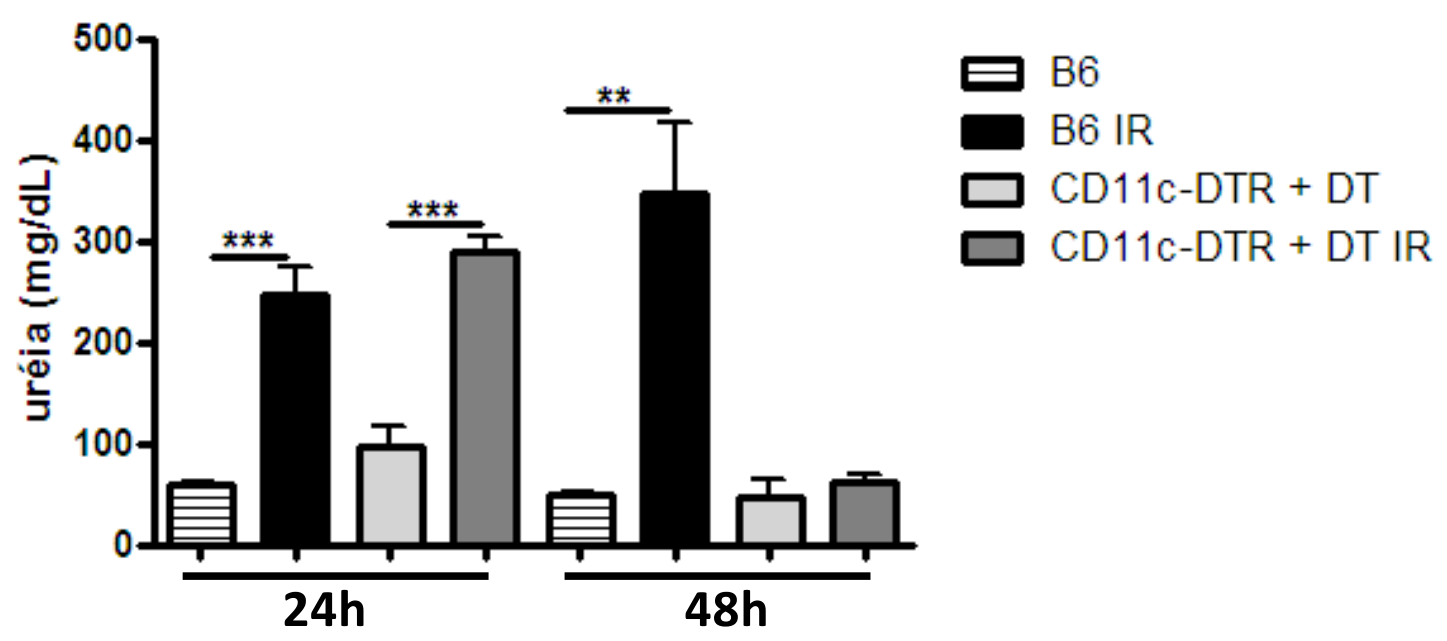

Figura 21. Depleção de $D C$ em animais CD11c-DTR protegeu da lesão por IR com $48 h$ de reperfusão. Analisamos a função renal pela concentração de uréia sérica em animais isquemiados e reperfundidos por 24 e $48 \mathrm{~h}$. Nenhuma diferença entre o grupo depletado e não depletado em 24 h foi observada, mas houve menor lesão em $48 \mathrm{~h}$ de reperfusão em animais depletados. ${ }^{* *} \mathrm{P}<0,01 ;{ }^{* *} \mathrm{P}<0,001$.

Mais uma vez, checamos a ativação das DC pela expressão da molécula CD86 por citometria de fluxo e observamos que neste caso, as DC renais estavam mais ativadas no grupo depletado (Figura 22 A) com 24 h de reperfusão. Decidimos então analisar o fenótipo dos linfócitos $\mathrm{T} \mathrm{CD4}^{+}$e vimos que nas mesmas $24 \mathrm{~h}$ os linfócitos $\mathrm{T} \mathrm{CD4}^{+}$do linfonodo renal apresentavam maior expressão da molécula CD69 (Figura 22 B), indicando uma maior ativação, embora nenhuma diferença tenha sido observada na expressão de CD25 e de FOXP3 (Figura 22 C e D). 

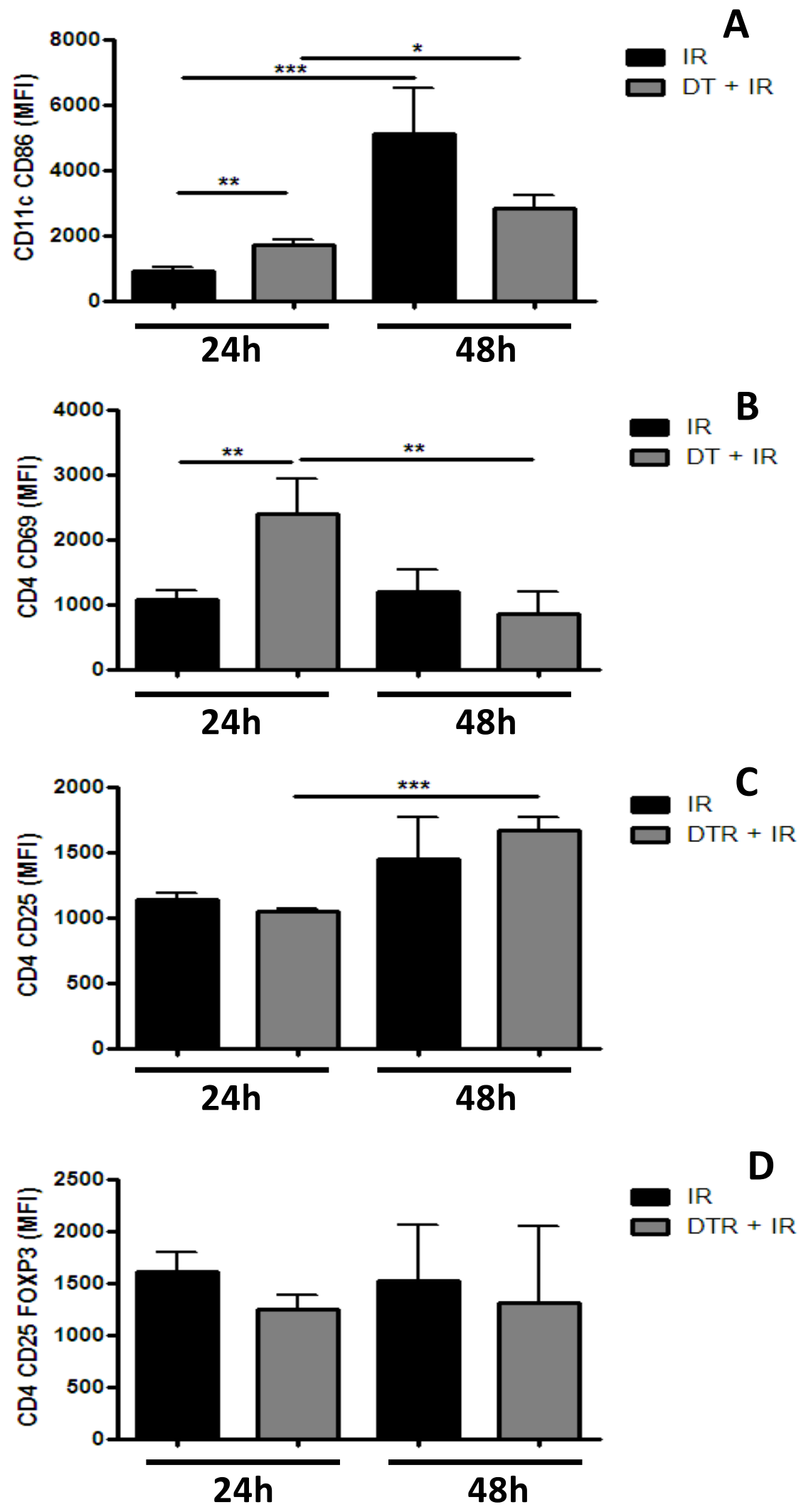

Figura 22. Depleção de $D C$ em animais CD11c-DTR levou à maior ativação de $D C$ e linfócitos T CD4. Analisamos por citometria de fluxo em 24 e $48 \mathrm{~h}$ de reperfusão a presença de moléculas de ativação de DC no rim: (A) CD86; e de linfócitos T CD4 no linfonodo: (B) CD69, (C) CD25 e a molécula de regulação (D) FOXP3. Observamos maior ativação de DC e linfócitos em 24 $h$ de reperfusão. ${ }^{*} \mathrm{P}<0,05 ;{ }^{*} \mathrm{P}<0,01 ;{ }^{* *} \mathrm{P}<0,001$. 
Estes resultados indicam que as DC estão envolvidas no desenvolvimento da lesão, uma vez que a depleção das mesmas levou a uma menor lesão com $48 \mathrm{~h}$ de reperfusão, porém não descartam a possibilidade de essas células estarem envolvidas no controle da lesão juntamente com outras células, uma vez que a depleção por clodronato não apresentou proteção e a ausência de DC em animais CD11c-DTR apresentou maior ativação de linfócitos T CD4.

Baseado nestes dados e na literatura, que indicam uma participação das DC na lesão por IR, decidimos verificar se estas poderiam estar envolvidas na proteção observada pela indução de HO-1.

\subsection{O efeito da HO-1 na ativação de DC}

Inicialmente, confirmamos que o Hemin é capaz de alterar o fenótipo de ativação de DC in vitro. Adicionamos Hemin em DC diferenciadas de medula óssea e estimulamos estas células com LPS. Como observado na figura 23, as moléculas CD40, CD80 e CD86 estavam menos expressas na presença do Hemin, indicando um perfil menos ativado. 


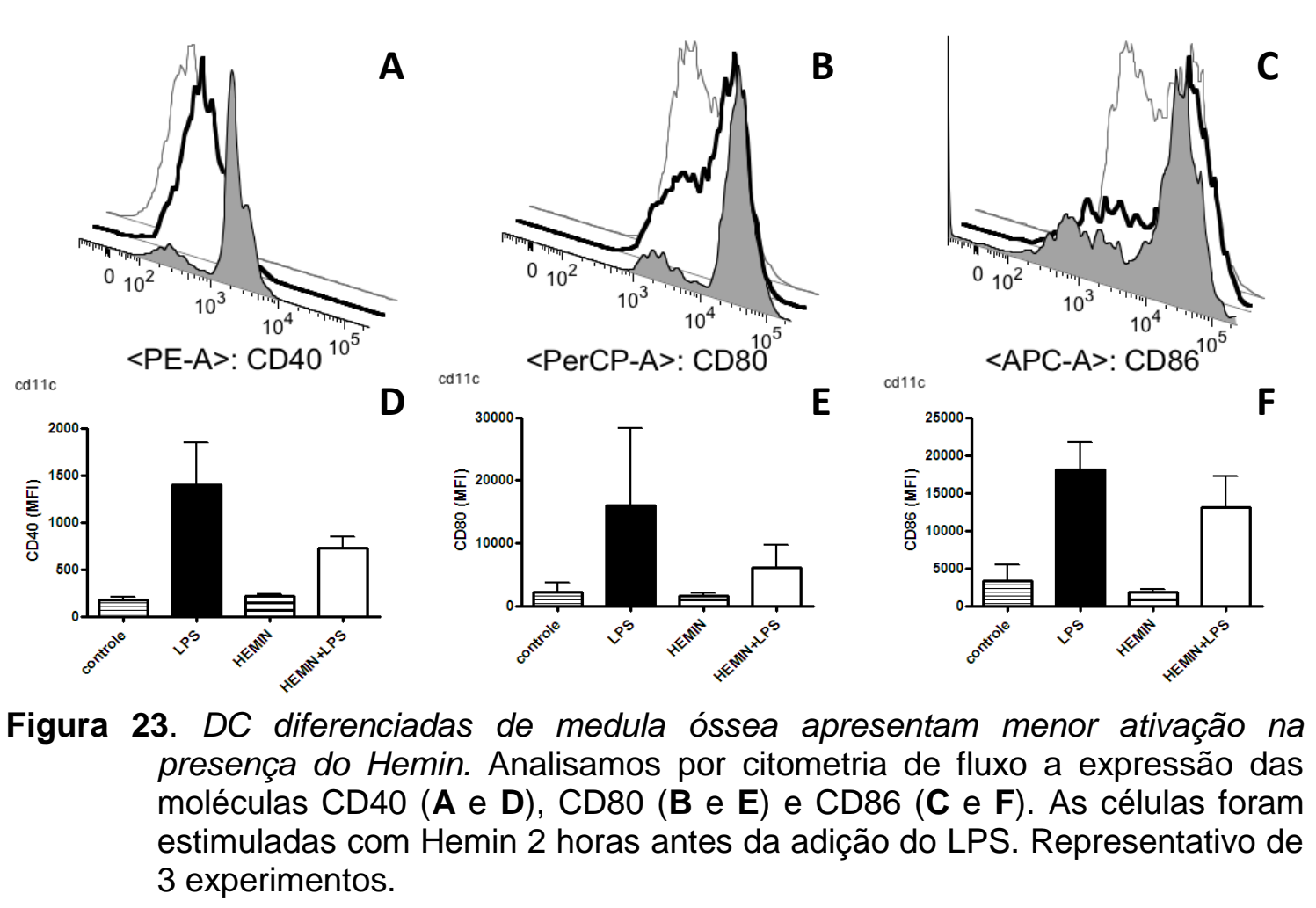

Estes resultados mostram que o Hemin pode atuar de maneira direta em DC e com isto, levar a um perfil menos ativado, que pode influenciar outras respostas. Assim, decidimos analisar o impacto do hemin nas DC no modelo de IR renal. Utilizando animais que apresentam o CD11c que carrega uma proteína fluorescente amarela (YFP), analisamos a frequência e ativação de DC no rim e nos linfonodos. Observamos que, embora haja uma queda no número de $\mathrm{DC}$ após a $\mathrm{IR}$, o número de $\mathrm{DC}$ não é alterado na presença de Hemin, tanto no rim quanto no linfonodo (Figura 24 A e B). No entanto, notamos um aumento de ativação de DC no rim (Figura $24 \mathbf{C}$ ), mas não no linfonodo (Figura 24 D), na presença de Hemin após 24 h de reperfusão. 

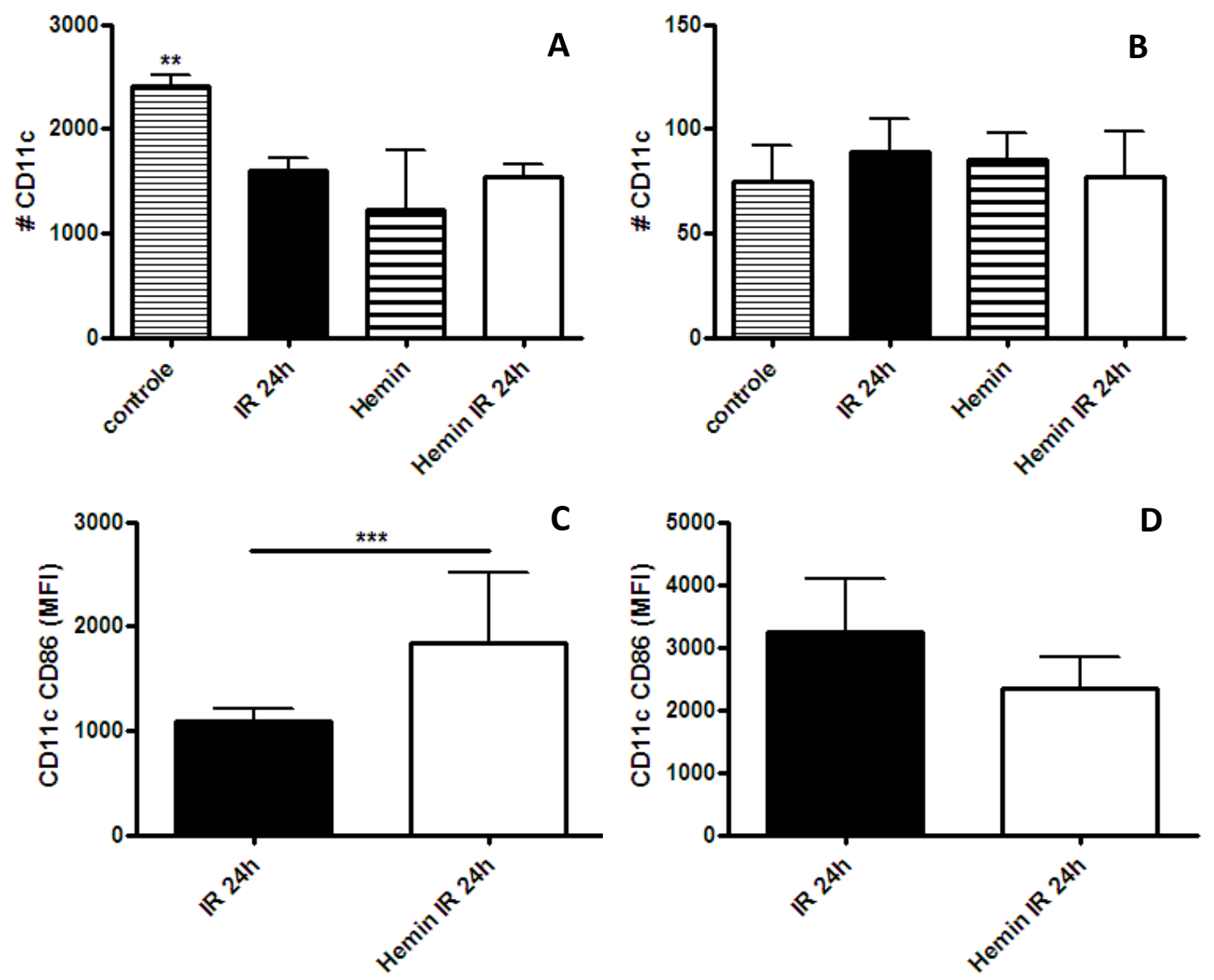

Figura 24. Animais CD11c-YFP apresentam maior expressão de CD86 em DC na presença do Hemin. Analisamos a frequência de $D C$ no rim $(\mathbf{A})$ e no linfonodo renal (B) por citometria de fluxo. Pela mesma metodologia, analisamos a ativação de DC pela expressão das moléculas CD86 em células CD11 $\mathrm{C}^{+}$, tanto no rim (C), quanto no linfonodo (D). ${ }^{* *} \mathrm{P}<0,001$. 
O mesmo resultado foi observado em animais C57BI6 (Figura 25) com $24 \mathrm{~h}$ de reperfusão, indicando não ser um artefato da linhagem CD11c-YFP. E embora nenhuma diferença significante tenha sido observada na expressão de CD86 no linfonodo, em ambas as linhagens de camundongo observamos uma tendência à menor expressão desta molécula nos linfonodos. Nenhuma diferença foi observada em outros marcadores de ativação (Figura 25), embora em alguns casos haja maior ou menor expressão dependendo do tempo de reperfusão, mas diferença que acompanha o grupo tratado e não tratado com Hemin. A única molécula que apresentou diferença de expressão fora o CD86, foi a molécula CD80, que no início da resposta é menos expressa em DC do rim tratado com Hemin (Figura $25 \mathrm{C}$ ), o que vai de acordo com os dados obtidos in vitro. 

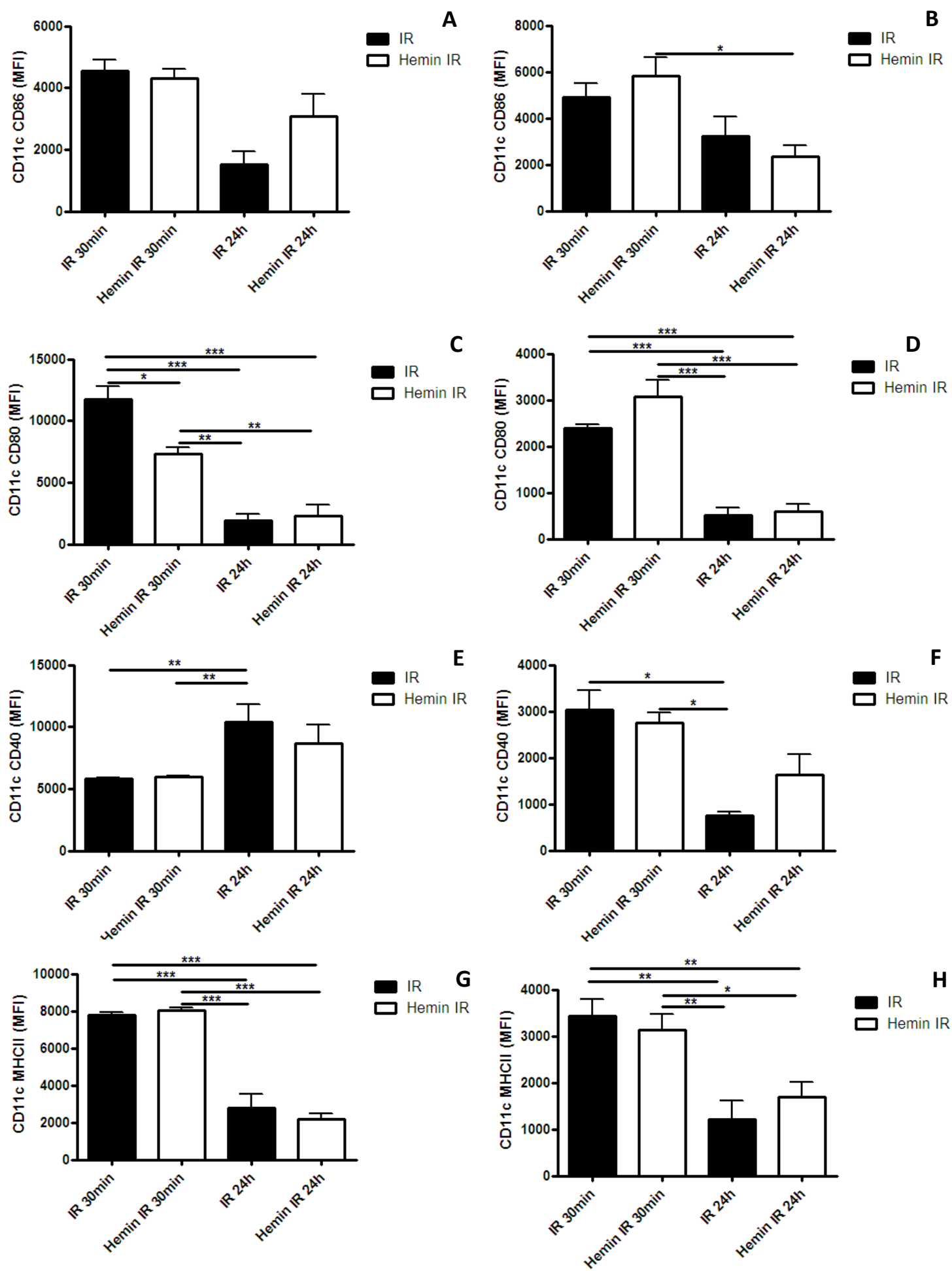

Figura 25. $D C$ do rim de animais C57BI6 apresentam mesma modulação de animais CD11c-YFP com tratamento de Hemin. Analisamos a expressão das moléculas de ativação CD86 (A e B), CD80 (C e D), CD40 (E e F) e MHC II (G e H) por FACS no rim (esquerda) e nos linfonodos (direita). ${ }^{*} \mathrm{P}<0,05$; ${ }^{* *} \mathrm{P}<0,01 ;{ }^{* *} \mathrm{P}<0,001$. 


\subsection{O efeito do tratamento com CORM na ativação de DC}

Para verificar se subprodutos da clivagem de heme pela $\mathrm{HO}-1$ poderiam modular DC da mesma forma, tratamos animais com CORM e realizamos a IR. Observamos proteção da lesão com o tratamento de CORM (Figura 26 A). Como no experimento in vitro observamos que as moléculas CD80, CD86, MHC de classe II e CD40, que indicam ativação de DC estavam menos expressas em DC do rim de animais tratados com Hemin (Figura 26 B, C, D e E).
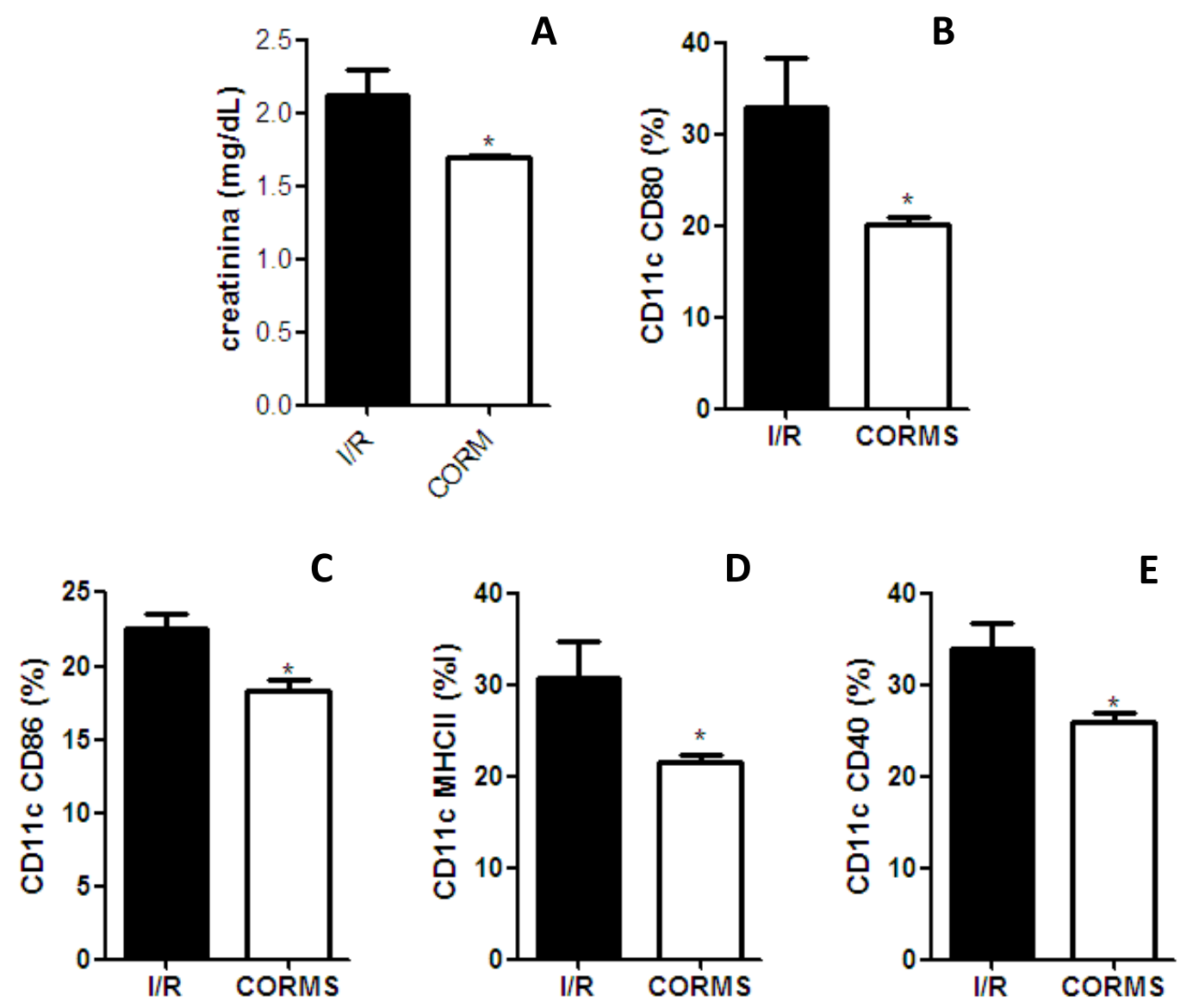

Figura 26. Animais tratados com CORMs apresentaram proteção e menor ativação de DC. Tratamos animais com um subproduto de ativação de HO-1 (CORMs) e analisamos a função renal pela concentração de creatinina (A). Por FACS, analisamos a expressão das moléculas CD80 (B), CD86 (C), MHC II (D) e CD40 (E) nas DC renais. $\boldsymbol{n}=5$ animais por grupo. ${ }^{*} \mathrm{P}<0,05$. 
Estes resultados sugerem que o Hemin module o fenótipo das DC renais durante o processo de IR. No entanto, por não ser de maneira homogênea entre as moléculas de ativação, não podemos afirmar que elas apresentem um perfil mais pró- ou anti-inflamatório.

\subsection{O Hemin diminui a produção de TNF-a de DC renais}

Para melhor analisar o efeito da $\mathrm{HO}-1$ nas $\mathrm{DC}$ no modelo de $\mathrm{IR}$, decidimos analisar citocinas conhecidas por apresentar atuarem em respostas pró-inflamatórias. Nenhuma diferença foi observada na concentração sérica de IL-6 e IL-1a, no entanto, TNF-a estava em menores concentrações no soro tanto no início quanto em $24 \mathrm{~h}$ de reperfusão (Figura 27).
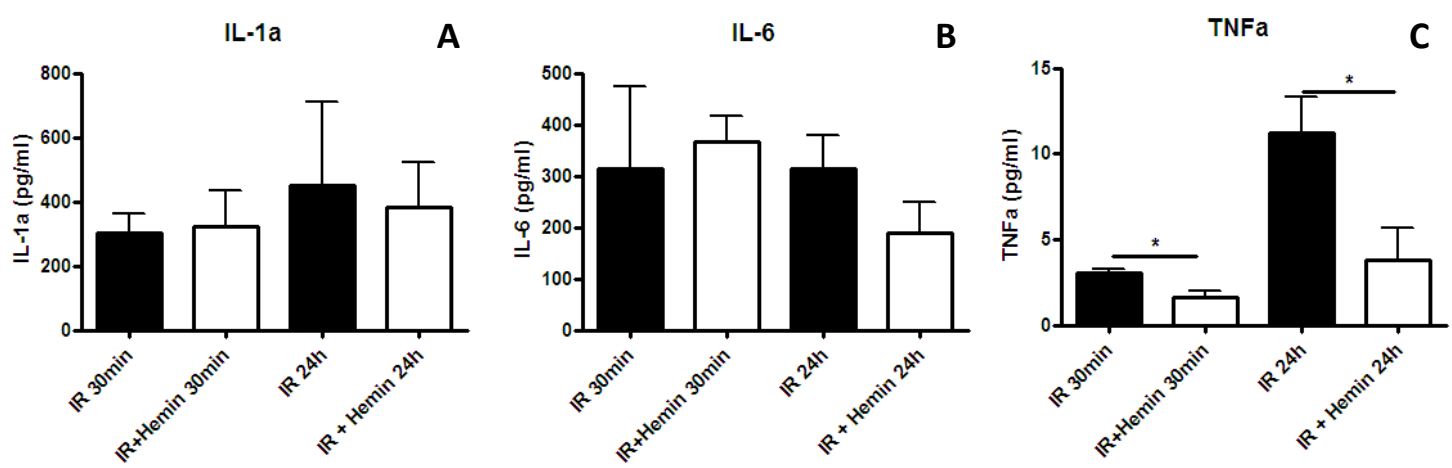

Figura 27. Tratamento com Hemin leva a menores concentrações de TNF-a. Citocinas pró-inflamatórias foram analisadas para ver a modulação do Hemin após IR. Níveis de IL-1a (A) e IL-6 (B) não apresentaram diferença, enquanto TNFa estava diminuído em $30 \mathrm{~min}$ e $24 \mathrm{~h}$ de reperfusão em animais tratados. $\boldsymbol{n}=5$ animais por grupo. ${ }^{*} \mathrm{P}<0,05$.

Para confirmar que esta diferença de TNF-a seria proveniente da produção por DC renais, nós analisamos por citometria de fluxo a produção de TNF-a e verificamos que DC é a principal fonte desta citocina no rim (Figura 28), tanto nos animais isquemiados que receberam Hemin, quanto nos não tratados (Figura $28 \mathrm{E}$ ). 

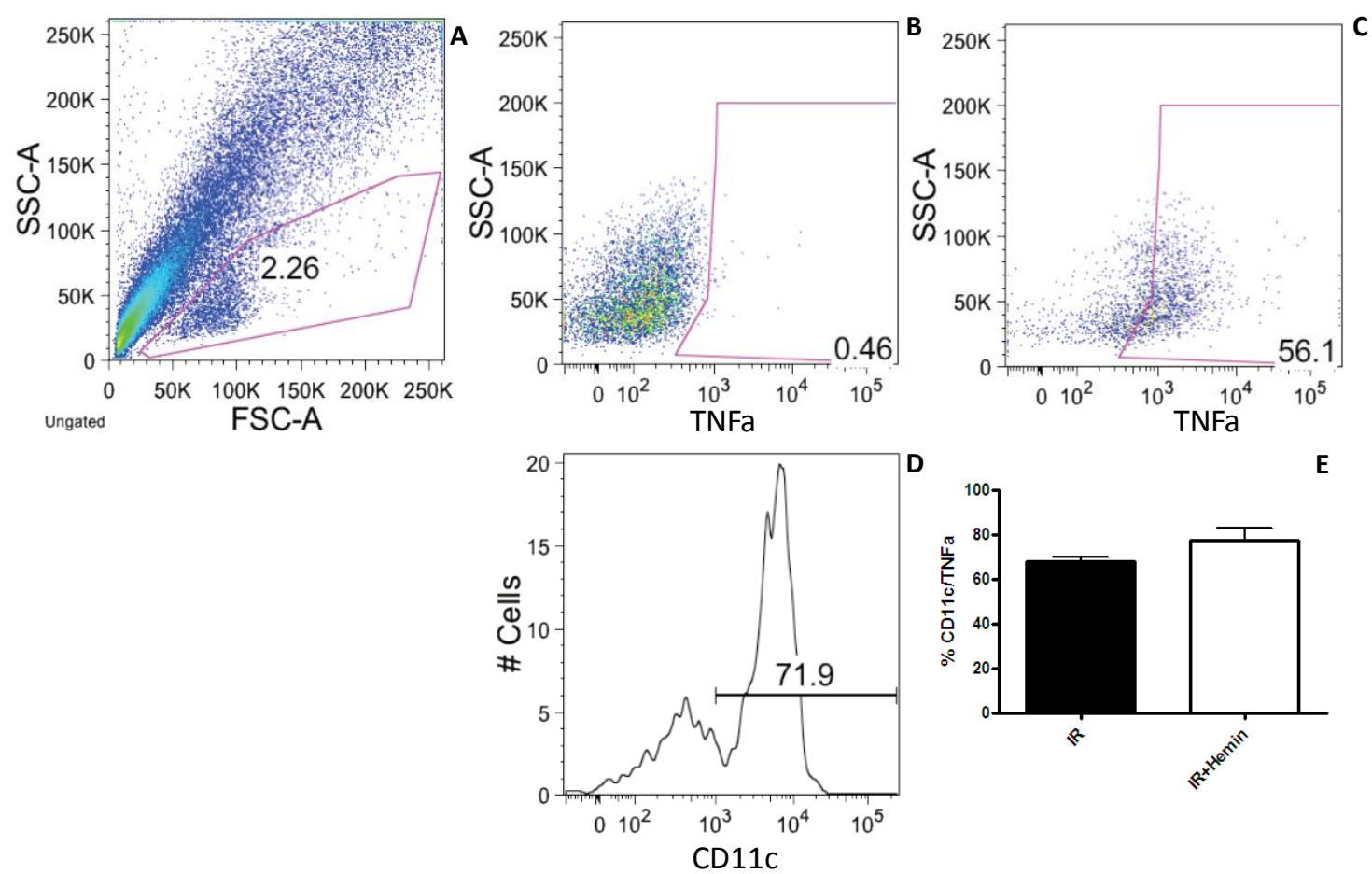

Figura 28. $D C$ é a principal produtora de TNFa no rim. A) determinamos o gate de células vivas. B) Determinamos o limite de células negativas e positivas com um controle isotipo em células renais. C) Determinamos onde estariam as células produtoras de TNFa. D) Dentre as células produtoras de TNFa, determinamos quais eram CD11 $\mathrm{C}^{+}$. E) Analisamos a frequência de células CD11c produtoras de TNFa entre os grupos submetidos à IR somente (barra preta) ou tratados com Hemin (barra branca). Representativo de 4 animais por grupo.

Além de verificar que a principal fonte de TNF-a no rim é a DC, também vimos que em 30 min de reperfusão há uma tendência à menor produção de TNF-a em rim de animais tratados com Hemin, tanto pela análise de citometria de fluxo, quanto pela análise de proteínas do tecido renal por bioplex (Figura 29 A e B). Além disso, a expressão gênica do TNF-a no rim após $24 \mathrm{~h}$ de reperfusão deixa claro que há menor produção de TNF-a em animais tratados com Hemin (Figura 29 C), confirmando que a HO-1 de certa forma modula DC renais dirigindo para uma menor produção de TNF-a. 

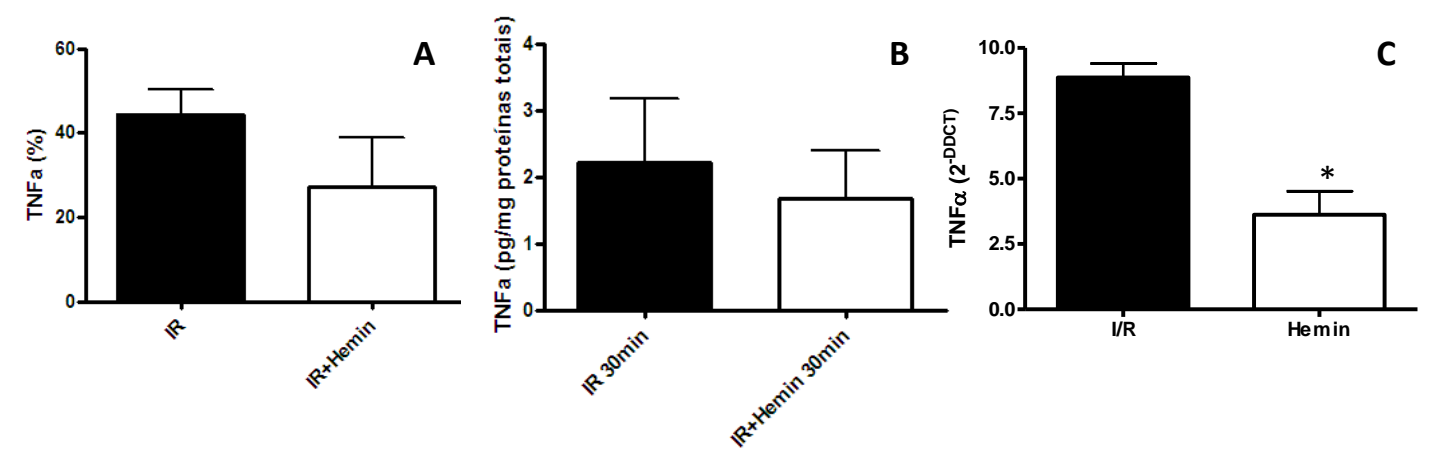

Figura 29. O tratamento com Hemin leva a menores expressão gênica de TNF-a no rim. Analisamos os níveis de TNF-a no rim por FACS $(\mathbf{A})$ e bioplex $(\mathbf{B})$ com $30 \mathrm{~min}$ de reperfusão. A expressão gênica de TNF-a foi analisada no rim após $24 \mathrm{~h}$ de reperfusão (C). $\boldsymbol{n}=5$ animais por grupo. ${ }^{*} \mathrm{P}<0,05$.

Nossos dados demonstram que a indução da HO-1 é capaz de gerar uma proteção contra a lesão renal por isquemia e reperfusão através da modulação de DC intra-renais, que apresentam menor produção de TNF-a, o que consequentemente diminui a resposta inflamatória e leva a outro fim outros tipos celulares. 


\section{DISCUSSÃO}

Por ser a principal causa da insuficiência renal aguda, a isquemia e reperfusão renal tem sido estudada no intuito de melhor compreendermos os mecanismos envolvidos em seu desenvolvimento e assim ampliarmos as possibilidade de terapia. Embora seja uma lesão de resposta rápida, nos últimos anos vários autores demonstraram a presença de células da imunidade adaptativa neste modelo. Neste trabalho, confirmamos o envolvimento de DC neste modelo e modulação destas células na presença de um indutor de HO-1 levando a uma resposta menos inflamatória com concomitante diminuição da lesão renal.

Diversos trabalhos mostram um papel anti-inflamatório da $\mathrm{HO}-1$ incluindo nosso grupo [74, 76], que mostrou a proteção da lesão renal aguda e crônica com aumento de HO-1. Nossos resultados mostrados na figura 2, confirmaram o aumento da HO-1 frente ao estímulo Hemin e a proteção da lesão renal com o aumento desta enzima. Além disso, mostramos que houve supressão de RANTES e MCP-1 no soro (Figura 3) associados ao aumento de HO-1. A expressão de RANTES é regulada positivamente na IR [59]. Sabe-se também que células endoteliais sob hipóxia apresentam menor expressão de RANTES após tratamento de indometacina, inibidor de cicloxigenase, que também diminui a expressão de HO-1 [77]. No entanto, a indução de HO-1 por Hemin não altera níveis de RANTES no pâncreas. Já a participação de MCP-1 com a HO-1 foi observada em um trabalho que mostra que animais knockout para tal enzima apresentam níveis basais de MCP-1 elevados [78], o que vai de acordo com nossos resultados. Esta quimiocina também é um biomarcador de lesão inflamatória no túbulo intersticial [79], o que mais uma vez confirma a proteção observada em animais tratados com Hemin. Como estas quimiocinas estão associadas à atração de linfócitos $T$ e monócitos, a modulação das mesmas pelo aumento de HO-1 é um indício da participação desses tipos celulares na proteção da lesão.

Nos últimos anos, a participação de linfócitos $T$ na $I R$ tem ficado evidente. Rabb et al. [80], mostraram que um modelo particular deficiente de linfócitos $\mathrm{T} \mathrm{CD}^{+}$e $\mathrm{T} \mathrm{CD8}{ }^{+}$, apresentava menor lesão renal em comparação 
com animais C57Bl6 de acordo com a concentração sérica de creatinina e presença de neutrófilos no rim. O mesmo grupo [49] mostrou que animais deficientes das cadeias $\alpha / \beta$ e $\gamma / \delta$ do TCR apresentavam proteção parcial da lesão por IR, além de menor expressão de TNF-a e IL-6. Ascon et al. [75], fenotiparam os linfócitos infiltrantes do rim e observaram um aumento de linfócitos T CD3+, linfócitos B CD19+ e células NK NK1.1+, acompanhados do aumento de TNF-a e IFN-g. Assim como na literatura, nós observamos que em 3 tipos de deficiência de linfócitos T: nude, SCID e MHC II KO (Figuras 4 e 5), houve proteção em relação a animais C57Bl6, reforçando a participação destas células no modelo de lesão renal aguda por IR.

Averiguada a participação de linfócitos $T$ na $I R$, a questão que nos fizemos foi se a proteção induzida pela HO-1 na IR renal, seria via ação de linfócitos $\mathrm{T} \mathrm{CD}^{+}$. Analisamos a proliferação de esplenócitos na presença de Hemin e observamos menor proliferação sem alterar a viabilidade celular (Figuras 6 e 7). Nesta situação, poderia se questionar se a menor proliferação não seria por ação indireta nos linfócitos $T$, uma vez que existem APCs nos esplenócitos. Esta questão torna-se relevante, uma vez que o grupo de Chora et al. (2007) [81] mostrou a diminuição da expressão de MHC de classe II em APCs, diminuindo a ativação de linfócitos $T$ e amenizando um quadro de autoimunidade. Porém, há dados na literatura que corroboram a hipótese de que também seria via direta nos linfócitos $\mathrm{T} \mathrm{CD} 4^{+}$, onde mostram o monóxido de carbono, um produto da clivagem da molécula heme pela HO-1, inibindo a proliferação de linfócitos $\mathrm{T} C D 4^{+}$humanos purificados e estimulados com antiCD3 e anti-CD28 [82]. Além disto, esta inibição de proliferação estaria envolvida com a diminuição da ativação de fator nuclear (NF-)kB e diminuição de IL-2 [82].

Desta forma, nossa investigação sobre o papel dos linfócitos $\mathrm{T} \mathrm{CD}^{+}$na proteção induzida por HO-1, seguiu adiante, passando pela análise do fenótipo de ativação destas células, onde não observamos diferenças significantes (Figuras 8 e 9), chegando ao estudo de citocinas que indicaram menor produção de IFN-g e tendência à menor produção de IL-2 pelos linfonodos renais (Figura10) na indução da HO-1. Estes dados confirmam mais uma vez a menor lesão, uma vez que IFN-g além de ser uma citocina pró-inflamatória, 
está diretamente associada ao desenvolvimento da lesão renal aguda induzida

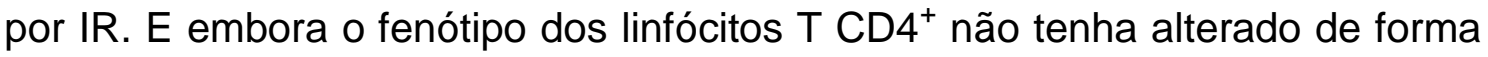
significante, a diferença da expressão de citocinas não nos deixa excluir a participação de linfócitos T CD4 $4^{+}$da proteção pela HO-1.

Assim, realizamos a transferência de esplenócitos tratados com Hemin, o que nos levou a crer que a proteção seria transferível pelo prévio tratamento de linfócitos $\mathrm{T} \mathrm{CD} 4^{+}$, uma vez que observamos menor lesão renal (Figura 11) além da maior frequência de linfócitos $T$ reguladores (Figura 12). No entanto, fomos surpreendidos pela ausência de proteção quando transferimos linfócitos T CD4 ${ }^{+}$purificados previamente tratados com Hemin e não obtivemos proteção contra a lesão renal em relação à transferência de células não tratadas (Figura 14). Além disto, a frequência de Tregs passou a ser menor no grupo que recebeu células tratadas com Hemin (Figura 15). Estes dados não excluem a possibilidade do envolvimento de linfócitos $\mathrm{T} \mathrm{CD}^{+}$na proteção pela $\mathrm{HO}-1$, mas indicam que se houver um papel destas células nesta proteção, dependerá de outras células ou de um ambiente próprio para que estas assumam um papel regulador.

Considerando o conjunto de resultados que obtivemos, decidimos investigar o papel das DC, uma vez que são APCs e poderiam afetar a proliferação e ativação de linfócitos $\mathrm{T} \mathrm{CD}^{+}$, não invalidando os dados que indicam a participação de linfócitos $T$, mas contribuindo para um melhor entendimento do fenômeno de proteção da lesão renal por HO-1.

No intuito de verificar o papel da DC na IR, utilizamos dois métodos de depleção de DC. Observamos que a depleção de fagócitos pela introdução de lipossomos contendo clodronato não levou a uma proteção contra a lesão por IR (Figura 18), enquanto a depleção pela adição da toxina diftérica em animais CD11c-DTR apresentou uma proteção com $48 \mathrm{~h}$ de reperfusão (Figura 21). Estes dados sugerem que as DC não são essenciais para iniciar o processo de lesão renal. Kim et al. (2010) [83], utilizaram o mesmo protocolo de depleção de fagócitos pelo clodronato e também viram que em $24 \mathrm{~h}$ não havia proteção no grupo depletado. Além disso, mostraram que em momentos tardios, como 5 a 7 dias, as DC eram importantes para a produção de IL-10, sugerindo um 
papel no controle da lesão. Esses dados concordam com os nossos resultados obtidos pela adição do clodronato. No caso da proteção observada em animais CD11c-DTR que receberam a toxina, apenas células $C D 11 c^{+}$foram eliminadas, o que pode explicar a resposta diferente da obtida com clodronato. Além disso, pode ser que a DC tenha um papel na manutenção da lesão durante um certo período e depois passe a ter uma função de regulação. Estudos mais detalhados serão necessários para confirmar estas hipóteses. O que nos é relevante, é que de certa forma as DC estão envolvidas na IR e que podem ser as responsáveis por direcionar a resposta de linfócitos $\mathrm{T} \mathrm{CD4}^{+}$para a contribuição da lesão.

Voltando ao nosso questionamento principal: será que a $\mathrm{HO}-1$ poderia modular DC levando a um fim diferente a lesão por IR? Observamos que o tratamento de DC derivadas de medula óssea com Hemin in vitro levou as DC a um fenótipo de menor ativação (Figura 23), fenômeno descrito por outros autores em células humanas e células de ratos [84]. $\mathrm{Na}$ análise in vivo, notamos uma inversão na expressão da molécula CD86 nos animais tratados com Hemin, pois esta se apresentava mais expressa em relação a animais não tratados (Figura 24 e 25). Já a molécula CD80, estava menos expressa em animais tratados com Hemin (Figura 25), da mesma forma que os resultados observados in vitro. Da mesma forma, o subproduto da ativação de HO-1, CO, induziu a menor ativação de DC no rim (Figura 26), indicando que a HO-1 leva a um perfil menos inflamatório, sendo uma das razões a produção de $\mathrm{CO}$.

Como o fenótipo celular não representa necessariamente a função da célula, decidimos analisar uma citocina crucial para responder se as DC estavam sendo moduladas no contexto de $\mathrm{HO}-1$ de forma a contribuir para a proteção da lesão. Sabemos que o TNF-a é majoritariamente produzido por DC no rim após a isquemia [59]. Confirmamos este dado pela citometria de fluxo com marcação intracelular de células renais e conferimos que tanto animais não tratados como tratados com Hemin eram capazes de produzir TNF-a e em ambos os casos esta produção era feita principalmente por $\mathrm{DC}$. Na análise de expressão gênica de TNF-a do rim, confirmamos a modulação de DC com menor produção de TNF-a após o tratamento de Hemin. 
Desta forma, confirmamos que as DC intra-renais contribuem para a proteção induzida pela HO-1 contra a lesão por IR, pela modulação que faz com que a produção de TNF-a produzido após a isquemia seja contida. A relação da DC com a HO-1 pode ir além do controle de produção de TNF-a. Nossos resultados dão margem à participação indireta de linfócitos T CD4 ${ }^{+}$, que por uma ativação diferenciada das DC moduladas poderiam produzir menos IFN-g, ou essas mesmas DC poderiam levar a uma maior diferenciação de linfócitos $T$ para Tregs, ou ainda as DC poderiam migrar menor para os linfonodos, diminuindo toda a resposta que poderia ser gerada no linfonodo.

Nossos dados sugerem que, a HO-1 é importante para a proteção contra a lesão induzida por IR renal. Esta proteção é associada à modulação de DC que passa a apresentar um fenótipo diferente do encontrado na ausência do estímulo prévio da HO-1 de forma a produzir menos TNF-a. Assim, a relevância deste estudo consiste na melhor manipulação da HO-1 na proteção da lesão renal aguda, para possível utilização na clínica e em diversos modelos que envolvem descontrole da resposta inflamatória. 


\section{CONCLUSÃO}

No modelo de IR renal as DC participam do desenvolvimento da lesão renal, contribuindo com a produção de TNF-a. $\mathrm{Na}$ indução da HO-1, a lesão pode ser amenizada através da modulação das DC renais que passam a ser menos ativadas e a produzir menos TNF-a, podendo afetar de maneira generalizada outras células para um perfil mais protetor. 


\section{REFERÊNCIAS ${ }^{1}$}

[1] Bonventre JV, Zuk A. Ischemic acute renal failure: an inflammatory disease? Kidney Int. 2004 Aug;66(2):480-5.

[2] Ympa YP, Sakr Y, Reinhart K, Vincent JL. Has mortality from acute renal failure decreased? A systematic review of the literature. Am J Med. 2005 Aug;118(8):827-32.

[3] White LE, Hassoun HT. Inflammatory Mechanisms of Organ Crosstalk during Ischemic Acute Kidney Injury. International Journal of Nephrology. 2012:505197. In press.

[4] Urbschat A, Obermuller N, Haferkamp A. Biomarkers of kidney injury. Biomarkers. 2011 Jul;16(Suppl 1):S22-30.

[5] Cecka JM, Cho YW, Terasaki PI. Analyses of the UNOS Scientific Renal Transplant Registry at three years--early events affecting transplant success. Transplantation. 1992 Jan;53(1):59-64.

[6] Paul LC. Chronic allograft nephropathy: An update. Kidney Int. 1999 Sep;56(3):783-93.

[7] Jang HR, Ko GJ, Wasowska BA, Rabb H. The interaction between ischemia-reperfusion and immune responses in the kidney. Journal of Molecular Medicine (Berlin, Germany). 2009 Sep;87(9):859-64.

[8] Land WG. The role of postischemic reperfusion injury and other nonantigen-dependent inflammatory pathways in transplantation. Transplantation. 2005 Mar 15;79(5):505-14.

[9] Kim BS, Lim SW, Li C, Kim JS, Sun BK, Ahn KO, et al. Ischemiareperfusion injury activates innate immunity in rat kidneys. Transplantation. 2005 May 27;79(10):1370-7.

[10] Leemans JC, Stokman G, Claessen N, Rouschop KM, Teske GJ, Kirschning CJ, et al. Renal-associated TLR2 mediates ischemia/reperfusion injury in the kidney. J Clin Invest. 2005 Oct;115(10):2894-903.

[11] Shigeoka AA, Holscher TD, King AJ, Hall FW, Kiosses WB, Tobias PS, et al. TLR2 is constitutively expressed within the kidney and participates in ischemic renal injury through both MyD88-dependent and -independent pathways. J Immunol. 2007 May 15;178(10):6252-8.

\footnotetext{
${ }^{1}$ De acordo com:

International Committee of Medical Journal Editors. Uniform requirements for manuscripts submitted to Biomedical Journal: sample references. Available from: http://www.icmje.org [2007 May 22].
} 
[12] Kruger B, Krick S, Dhillon N, Lerner SM, Ames S, Bromberg JS, et al. Donor Toll-like receptor 4 contributes to ischemia and reperfusion injury following human kidney transplantation. Proc Natl Acad Sci U S A. 2009 Mar 3;106(9):3390-5.

[13] Huang $\mathrm{Y}$, Rabb $\mathrm{H}$, Womer $\mathrm{KL}$. Ischemia-reperfusion and immediate $\mathrm{T}$ cell responses. Cellular Immunology. 2007 Jul;248(1):4-11.

[14] Zhou W, Farrar CA, Abe K, Pratt JR, Marsh JE, Wang Y, et al. Predominant role for C5b-9 in renal ischemia/reperfusion injury. J Clin Invest. 2000 May;105(10):1363-71.

[15] de Vries B, Walter SJ, Peutz-Kootstra CJ, Wolfs TG, van Heurn LW, Buurman WA. The mannose-binding lectin-pathway is involved in complement activation in the course of renal ischemia-reperfusion injury. Am J Pathol. 2004 Nov;165(5):1677-88.

[16] Ramesh G, Reeves WB. Inflammatory cytokines in acute renal failure. Kidney Int Suppl. 2004 Oct(91):S56-61.

[17] Thornton MA, Winn R, Alpers CE, Zager RA. An evaluation of the neutrophil as a mediator of in vivo renal ischemic-reperfusion injury. Am $\mathrm{J}$ Pathol. 1989 Sep;135(3):509-15.

[18] Rabb H, Mendiola CC, Dietz J, Saba SR, Issekutz TB, Abanilla F, et al. Role of CD11a and CD11b in ischemic acute renal failure in rats. Am J Physiol. 1994 Dec;267(6 Pt 2):F1052-8.

[19] Li L, Huang L, Sung SS, Lobo PI, Brown MG, Gregg RK, et al. NKT cell activation mediates neutrophil IFN-gamma production and renal ischemiareperfusion injury. J Immunol. 2007 May 1;178(9):5899-911.

[20] Li L, Huang L, Vergis AL, Ye H, Bajwa A, Narayan V, et al. IL-17 produced by neutrophils regulates IFN-gamma-mediated neutrophil migration in mouse kidney ischemia-reperfusion injury. J Clin Invest. 2010 Jan;120(1):33142.

[21] Feng L, Cheng F, Ye Z, Li S, He Y, Yao X, et al. The effect of renal ischemia-reperfusion injury on expression of RAE-1 and $\mathrm{H} 60$ in mice kidney. Transplant Proc. 2006 Sep;38(7):2195-8.

[22] Zhang PL, Rothblum LI, Han WK, Blasick TM, Potdar S, Bonventre JV. Kidney injury molecule-1 expression in transplant biopsies is a sensitive measure of cell injury. Kidney Int. 2008 Mar;73(5):608-14.

[23] Burne-Taney MJ, Ascon DB, Daniels F, Racusen L, Baldwin W, Rabb H. $B$ cell deficiency confers protection from renal ischemia reperfusion injury. $J$ Immunol. 2003 Sep 15;171(6):3210-5. 
[24] Jang HR, Gandolfo MT, Ko GJ, Satpute SR, Racusen L, Rabb H. B cells limit repair after ischemic acute kidney injury. J Am Soc Nephrol. 2010 Apr;21(4):654-65.

[25] Ysebaert DK, De Greef KE, Vercauteren SR, Ghielli M, Verpooten GA, Eyskens EJ, et al. Identification and kinetics of leukocytes after severe ischaemia/reperfusion renal injury. Nephrol Dial Transplant. 2000 Oct;15(10):1562-74.

[26] Li L, Huang L, Sung SS, Vergis AL, Rosin DL, Rose Jr. CE, et al. The chemokine receptors CCR2 and CX3CR1 mediate monocyte/macrophage trafficking in kidney ischemia-reperfusion injury. Kidney Int. 2008 Dec;74(12):1526-37.

[27] Jo SK, Sung SA, Cho WY, Go KJ, Kim HK. Macrophages contribute to the initiation of ischaemic acute renal failure in rats. Nephrol Dial Transplant. 2006 May;21(5):1231-9.

[28] Day YJ, Marshall MA, Huang L, McDuffie MJ, Okusa MD, Linden J. Protection from ischemic liver injury by activation of A2A adenosine receptors during reperfusion: inhibition of chemokine induction. American Journal of Physiology. 2004 Feb;286(2):G285-93.

[29] Vinuesa E, Hotter G, Jung M, Herrero-Fresneda I, Torras J, Sola A. Macrophage involvement in the kidney repair phase after ischaemia/reperfusion injury. J Pathol. 2008 Jan;214(1):104-13.

[30] Rabb H, O'Meara YM, Maderna P, Coleman P, Brady HR. Leukocytes, cell adhesion molecules and ischemic acute renal failure. Kidney Int. 1997 May;51(5):1463-8.

[31] Martin M, Mory C, Prescher A, Wittekind C, Fiedler M, Uhlmann D. Protective effects of early $\mathrm{CD} 4(+) \quad T$ cell reduction in hepatic ischemia/reperfusion injury. J Gastrointest Surg. 2010 Mar;14(3):511-9.

[32] Yang Z, Sharma AK, Linden J, Kron IL, Laubach VE. CD4+ T lymphocytes mediate acute pulmonary ischemia-reperfusion injury. The Journal of Thoracic and Cardiovascular Surgery. 2009 Mar;137(3):695-702.

[33] Shigematsu T, Wolf RE, Granger DN. T-lymphocytes modulate the microvascular and inflammatory responses to intestinal ischemia-reperfusion. Microcirculation. 2002 Apr;9(2):99-109.

[34] Solez K, Morel-Maroger L, Sraer JD. The morphology of "acute tubular necrosis" in man: analysis of 57 renal biopsies and a comparison with the glycerol model. Medicine (Baltimore). 1979 Sep;58(5):362-76.

[35] Chandraker A, Takada M, Nadeau KC, Peach R, Tilney NL, Sayegh MH. CD28-b7 blockade in organ dysfunction secondary to cold ischemia/reperfusion injury. Kidney Int. 1997 Dec;52(6):1678-84. 
[36] Takada M, Chandraker A, Nadeau KC, Sayegh MH, Tilney NL. The role of the B7 costimulatory pathway in experimental cold ischemia/reperfusion injury. J Clin Invest. 1997 Sep 1;100(5):1199-203.

[37] Kelly KJ, Williams Jr WW, Colvin RB, Bonventre JV. Antibody to intercellular adhesion molecule 1 protects the kidney against ischemic injury. Proc Natl Acad Sci U S A. 1994 Jan 18;91(2):812-6.

[38] Kelly KJ, Williams Jr WW, Colvin RB, Meehan SM, Springer TA, Gutierrez-Ramos JC, et al. Intercellular adhesion molecule-1-deficient mice are protected against ischemic renal injury. J Clin Invest. 1996 Feb 15;97(4):105663.

[39] Rabb H, Mendiola CC, Saba SR, Dietz JR, Smith CW, Bonventre JV, et al. Antibodies to ICAM-1 protect kidneys in severe ischemic reperfusion injury. Biochem Biophys Res Commun. 1995 Jun 6;211(1):67-73.

[40] Takada M, Nadeau KC, Shaw GD, Marquette KA, Tilney NL. The cytokine-adhesion molecule cascade in ischemia/reperfusion injury of the rat kidney. Inhibition by a soluble P-selectin ligand. J Clin Invest. 1997 Jun 1;99(11):2682-90.

[41] Goes N, Urmson J, Vincent D, Halloran PF. Acute renal injury in the interferon-gamma gene knockout mouse: effect on cytokine gene expression. Transplantation. 1995 Dec 27;60(12):1560-4.

[42] Goes N, Urmson J, Ramassar V, Halloran PF. Ischemic acute tubular necrosis induces an extensive local cytokine response. Evidence for induction of interferon-gamma, transforming growth factor-beta 1, granulocytemacrophage colony-stimulating factor, interleukin-2, and interleukin-10. Transplantation. 1995 Feb 27;59(4):565-72.

[43] Lemay S, Rabb H, Postler G, Singh AK. Prominent and sustained upregulation of gp130-signaling cytokines and the chemokine MIP-2 in murine renal ischemia-reperfusion injury. Transplantation. 2000 Mar 15;69(5):959-63.

[44] Pinheiro HS, Camara NO, Noronha IL, Maugeri IL, Franco MF, Medina $\mathrm{JO}$, et al. Contribution of CD4+ T cells to the early mechanisms of ischemiareperfusion injury in a mouse model of acute renal failure. Brazilian Journal of Medical and Biological Research $=$ Revista Brasileira de Pesquisas Medicas e Biologicas. 2007 Apr;40(4):557-68.

[45] Burne MJ, Daniels F, El Ghandour A, Mauiyyedi S, Colvin RB, O'Donnell $\mathrm{MP}$, et al. Identification of the CD4(+) T cell as a major pathogenic factor in ischemic acute renal failure. J Clin Invest. 2001 Nov;108(9):1283-90.

[46] Yokota N, Burne-Taney M, Racusen L, Rabb H. Contrasting roles for STAT4 and STAT6 signal transduction pathways in murine renal ischemiareperfusion injury. Am J Physiol Renal Physiol. 2003 Aug;285(2):F319-25. 
[47] Marques VP, Goncalves GM, Feitoza CQ, Cenedeze MA, Fernandes Bertocchi AP, Damiao MJ, et al. Influence of $\mathrm{TH} 1 / \mathrm{TH} 2$ switched immune response on renal ischemia-reperfusion injury. Nephron Exp Nephrol. 2006;104(1):e48-56.

[48] Shackleton CR, Ettinger SL, McLoughlin MG, Scudamore CH, Miller RR, Keown PA. Effect of recovery from ischemic injury on class I and class II MHC antigen expression. Transplantation. 1990 Mar;49(3):641-4.

[49] Savransky V, Molls RR, Burne-Taney M, Chien CC, Racusen L, Rabb H. Role of the T-cell receptor in kidney ischemia-reperfusion injury. Kidney Int. 2006 Jan;69(2):233-8.

[50] Satpute SR, Park JM, Jang HR, Agreda P, Liu M, Gandolfo MT, et al. The role for $\mathrm{T}$ cell repertoire/antigen-specific interactions in experimental kidney ischemia reperfusion injury. J Immunol. $2009 \mathrm{Jul}$ 15;183(2):984-92.

[51] Monteiro RM, Camara NO, Rodrigues MM, Tzelepis F, Damiao MJ, Cenedeze MA, et al. A role for regulatory $T$ cells in renal acute kidney injury. Transplant Immunology. 2009 May;21(1):50-5.

[52] Kinsey GR, Sharma R, Huang L, Li L, Vergis AL, Ye H, et al. Regulatory $\mathrm{T}$ cells suppress innate immunity in kidney ischemia-reperfusion injury. J Am Soc Nephrol. 2009 Aug;20(8):1744-53.

[53] Gandolfo MT, Jang HR, Bagnasco SM, Ko GJ, Agreda P, Satpute SR, et al. Foxp3+ regulatory $\mathrm{T}$ cells participate in repair of ischemic acute kidney injury. Kidney Int. 2009 Oct;76(7):717-29.

[54] Banchereau J, Briere F, Caux C, Davoust J, Lebecque S, Liu YJ, et al. Immunobiology of dendritic cells. Annu Rev Immunol. 2000;18:767-811.

[55] Sallusto F, Lanzavecchia A. Mobilizing dendritic cells for tolerance, priming, and chronic inflammation. J Exp Med. 1999 Feb 15;189(4):611-4.

[56] Kaissling B, Le Hir M. Characterization and distribution of interstitial cell types in the renal cortex of rats. Kidney Int. 1994 Mar;45(3):709-20.

[57] Wu CJ, Sheu JR, Chen HH, Liao HF, Yang YC, Yang S, et al. Renal ischemia/reperfusion injury inhibits differentiation of dendritic cells derived from bone marrow monocytes in rats. Life Sci. 2006 Feb 2;78(10):1121-8.

[58] Dong X, Swaminathan S, Bachman LA, Croatt AJ, Nath KA, Griffin MD. Antigen presentation by dendritic cells in renal lymph nodes is linked to systemic and local injury to the kidney. Kidney Int. 2005 Sep;68(3):1096-108.

[59] Dong X, Swaminathan S, Bachman LA, Croatt AJ, Nath KA, Griffin MD. Resident dendritic cells are the predominant TNF-secreting cell in early renal ischemia-reperfusion injury. Kidney Int. 2007 Apr;71(7): 619-28. 
[60] Tenhunen R, Marver HS, Schmid R. The enzymatic conversion of heme to bilirubin by microsomal heme oxygenase. Proc Natl Acad Sci U S A. 1968 Oct;61(2):748-55.

[61] Maines MD, Trakshel GM, Kutty RK. Characterization of two constitutive forms of rat liver microsomal heme oxygenase. Only one molecular species of the enzyme is inducible. J Biol Chem. 1986 Jan 5;261(1):411-9.

[62] Gozzelino R, Jeney V, Soares MP. Mechanisms of cell protection by heme oxygenase-1. Annu Rev Pharmacol Toxicol. 2010;50:323-54.

[63] Soares MP, Marguti I, Cunha A, Larsen R. Immunoregulatory effects of HO-1: how does it work? Current Opinion in Pharmacology. 2009 Aug;9(4):4829.

[64] Baranano DE, Rao M, Ferris CD, Snyder SH. Biliverdin reductase: a major physiologic cytoprotectant. Proc Natl Acad Sci U S A. 2002 Dec 10;99(25):16093-8.

[65] Rocuts F, Zhang X, Yan J, Yue Y, Thomas M, Bach FH, et al. Bilirubin promotes de novo generation of $\mathrm{T}$ regulatory cells. Cell Transplantation. 2010;19(4):443-51.

[66] Adin CA, Croker BP, Agarwal A. Protective effects of exogenous bilirubin on ischemia-reperfusion injury in the isolated, perfused rat kidney. Am J Physiol Renal Physiol. 2005 Apr;288(4):F778-84.

[67] Otterbein LE, Kolls JK, Mantell LL, Cook JL, Alam J, Choi AM. Exogenous administration of heme oxygenase- 1 by gene transfer provides protection against hyperoxia-induced lung injury. J Clin Invest. 1999 Apr;103(7):1047-54.

[68] Wei Y, Chen P, de Bruyn M, Zhang W, Bremer E, Helfrich W. Carbon monoxide-releasing molecule-2 (CORM-2) attenuates acute hepatic ischemia reperfusion injury in rats. BMC Gastroenterology. 2010;10:42.

[69] Vera T, Henegar JR, Drummond HA, Rimoldi JM, Stec DE. Protective effect of carbon monoxide-releasing compounds in ischemia-induced acute renal failure. J Am Soc Nephrol. 2005 Apr;16(4):950-8.

[70] Berberat PO, Katori M, Kaczmarek E, Anselmo D, Lassman C, Ke B, et al. Heavy chain ferritin acts as an antiapoptotic gene that protects livers from ischemia reperfusion injury. Faseb J. 2003 Sep;17(12):1724-6.

[71] Tullius SG, Nieminen-Kelha M, Buelow R, Reutzel-Selke A, Martins PN, Pratschke $J$, et al. Inhibition of ischemia/reperfusion injury and chronic graft deterioration by a single-donor treatment with cobalt-protoporphyrin for the induction of heme oxygenase-1. Transplantation. 2002 Sep 15;74(5):591-8. 
[72] Goncalves GM, Cenedeze MA, Feitoza CQ, de Paula CB, Macusso GD, Pinheiro HS, et al. Heme oxygenase 1 and renal ischemia and reperfusion injury: the impact of immunosuppressive drug. Int Immunopharmacol. 2006 Dec 20;6(13-14):1966-72.

[73] Demirogullari B, Ekingen G, Guz G, Bukan N, Erdem O, Ozen IO, et al. A comparative study of the effects of hemin and bilirubin on bilateral renal ischemia reperfusion injury. Nephron Exp Nephrol. 2006;103(1):e1-5.

[74] Correa-Costa M, Semedo P, Monteiro AP, Silva RC, Pereira RL, Goncalves GM, et al. Induction of heme oxygenase-1 can halt and even reverse renal tubule-interstitial fibrosis. PLoS One. 2010;5(12):e14298.

[75] Ascon DB, Lopez-Briones S, Liu M, Ascon M, Savransky V, Colvin RB, et al. Phenotypic and functional characterization of kidney-infiltrating lymphocytes in renal ischemia reperfusion injury. J Immunol. 2006 Sep 1;177(5):3380-7.

[76] Goncalves GM, Cenedeze MA, Feitoza CQ, Wang PM, Bertocchi AP, Damiao $\mathrm{MJ}$, et al. The role of heme oxygenase 1 in rapamycin-induced renal dysfunction after ischemia and reperfusion injury. Kidney Int. 2006 Nov;70(10):1742-9.

[77] Gloria MA, Cenedeze MA, Pacheco-Silva A, Camara NO. The blockade of cyclooxygenases-1 and -2 reduces the effects of hypoxia on endothelial cells. Braz J Med Biol Res. 2006 Sep;39(9):1189-96.

[78] Pittock ST, Norby SM, Grande JP, Croatt AJ, Bren GD, Badley AD, et al. MCP-1 is up-regulated in unstressed and stressed $\mathrm{HO}-1$ knockout mice: Pathophysiologic Correlates. Kidney Int. 2005 Aug;68(2):611-22.

[79] Yokoyama T, Shimizu M, Ohta K, Yuno T, Okajima M, Wada T, et al. Urinary heme oxygenase-1 as a sensitive indicator of tubulointerstitial inflammatory damage in various renal diseases. American Journal of Nephrology. 2011;33(5):414-20.

[80] Rabb H, Daniels F, O'Donnell M, Haq M, Saba SR, Keane W, et al. Pathophysiological role of $\mathrm{T}$ lymphocytes in renal ischemia-reperfusion injury in mice. Am J Physiol Renal Physiol. 2000 Sep;279(3):F525-31.

[81] Chora AA, Fontoura P, Cunha A, Pais TF, Cardoso S, Ho PP, et al. Heme oxygenase-1 and carbon monoxide suppress autoimmune neuroinflammation. J Clin Invest. 2007 Feb;117(2):438-47.

[82] Pae HO, Oh GS, Choi BM, Chae SC, Kim YM, Chung KR, et al. Carbon monoxide produced by heme oxygenase-1 suppresses $\mathrm{T}$ cell proliferation via inhibition of IL-2 production. J Immunol. 2004 Apr 15;172(8):4744-51.

[83] Kim MG, Boo CS, Ko YS, Lee HY, Cho WY, Kim HK, et al. Depletion of kidney $\mathrm{CD} 11 \mathrm{C}+\mathrm{F} 4 / 80+$ cells impairs the recovery process in 
ischaemia/reperfusion-induced acute kidney injury. Nephrol Dial Transplant. 2010 Sep;25(9):2908-21.

[84] Chauveau C, Remy S, Royer PJ, Hill M, Tanguy-Royer S, Hubert FX, et al. Heme oxygenase-1 expression inhibits dendritic cell maturation and proinflammatory function but conserves IL-10 expression. Blood. 2005 Sep 1;106(5):1694-702. 